\title{
A Tale of Ulus Square: Emergence, Transformation and Change
}

\author{
Ulus Meydani’nın Hikâyesi: Oluşum, Dönüşüm ve Değiş̧im
}

\section{Elif Selena AYHAN KOÇYİĞİT}

Dr. Instructor, Başkent University, Faculty of Fine Arts, Design and Architecture, Department of Architecture, Ankara, Turkey esayhan@baskent.edu.tr

ORCID ID: 0000-0002-5704-320X

DOI: $10.5505 /$ jas.2019.82905

\begin{abstract}
This research focuses on the story of Ulus Square as a heritage place and its emergence, evolution and transformation through time. It is aimed to reveal the values that are ascribed to the area during the periods defined, and to determine the main factors that have affected how these values have been shaped over time. A particular emphasis has been placed on highlighting the vulnerability of Ulus Square in the face of current urban projects, and the risk of the area losing its cultural significance, authenticity and integrity as an important public open space within the city.

In the first part of the article, the integration, starting from the Roman Period onwards, of the empty open space (corresponding to today's Ulus Square) to the city is examined. Secondly, the emergence of the square in the early 19th century, and the subsequent acceleration of its development through the Tanzimat Reforms, is analysed in detail. In the following parts, effects on urban space and city life of several events and trends, such as the proclamation of the Republic, the declaration of Ankara as the capital and the ideological structure of the state is discussed through the story of Ulus Square. There is also consideration of the changes within the political, economic and sociocultural structure of the country after the Second World War, the impact of international relations on urban structure, and how the transformation of Ulus Square reflects these changes. The final section of the paper is mainly concerned with the role of conservation and renovation master plans on the continuity of Ulus Square. These plans are analysed regarding their impact on the square and the values attached to the area. The clear correlation between current projects and the renovation plan that was repealed in 2008 is particularly emphasised, and the negative impacts of these projects on the cultural significance of Ulus Square are discussed in detail.
\end{abstract}

Keywords: Historic public open space, Cultural heritage, Urban Conservation, Conservation master plan, Renovation plan, Ulus Square, Ankara

\footnotetext{
* The research covered in this work received the Koç University-VEKAM Library and Archive Research Award in 2017. This article is based on the Ph.D. Thesis A Tale of Ulus Square: A Critical Assessment of Continuity, Transformation and Change in a Historic Public Open Space in Ankara, prepared under the advisory of Prof. Dr. Neriman Şahin Güçhan in the Graduate Program in Conservation of Cultural Heritage, Graduate School of Natural and Applied Sciences, Middle East Technical University.

** Çalışmaya konu olan araştırma 2017 yılı Koç Üniversitesi-VEKAM Kütüphanesi ve Arşivi Araştırma Ödülü̉ne hak kazanmıştır. Makale, Orta Doğu Teknik Üniversitesi Fen Bilimleri Enstitüsü Kültürel Mirası Koruma Doktora Programinda Prof.Dr. Neriman Şahin Güçhan danışmanliğında gerçekleştirilen A Tale of Ulus Square: A Critical Assessment of Continuity, Transformation and Change in a Historic Public Open Space in Ankara adlı doktora tezine dayandırılarak hazırlanmıștır.
} 


\section{Öz}

Bu araştırma bir kültürel miras alanı olan Ulus Meydanı’nın tarihsel süreç içerisinde oluşum, gelişim ve dönüşüm hikâyesi üzerine odaklanmaktadır. Makalede, tariflenen dönemlere ait değerlerin ortaya çıkarılması ve bu değerlerin zaman içinde yaşadığı süreklilik, değişim ve dönüşümü etkileyen ana faktörlerin belirlenmesi hedeflenmektedir. Böylelikle bu makale ile kentin önemli kamusal açık alanlarından biri olarak tariflenen Ulus Meydanı’nın güncel uygulamalar doğrultusunda kültürel niteliğini, özgünlüğünü ve bütünlüğünü kaybetme tehlikesine dikkat çekmek amaçlanmaktadır.

Makalenin ilk bölümde, boş bir açık alan olarak Ulus Meydanı’nın tanımlamış olduğu bölgenin Roma döneminden itibaren günümüze dek kente entegre olma biçimi aktarılmış, zamanla bir meydan niteliği kazanmasını sağlayan tarihi süreç ve etmenler tartışılmıştır. İkinci bölümde ise 19. yy’dan itibaren, özellikle Tanzimat hareketlerinin yönetim yapısı ve kente olan etkileri sonucu başlayan meydanlaşma süreci detaylarıyla anlatılmıştır. Devam eden bölümlerde, Cumhuriyetin ilanının, Ankara’nın başkent olma sürecinin ve ideolojik yapının kent mekânına ve kentsel yaşama yansıması, Ulus Meydanı hikâyesi üzerinden tartışılmıştır. Takip eden bölümlerde, II. Dünya Savaşı sonrasında yaşanan politik, ekonomik ve sosyo-kültürel yapıdaki değişim, uluslararası ilişkilerin kentsel mekânın kurgusundaki rolü ve bu süreçte Ulus Meydanı’nın yeniden şekillenmesi incelenmiştir. Son bölümde ise, tarihi Ankara olarak tariflenen ve Ulus Meydanı ve yakın çevresinin de bir bölümünün dâhil edildiği bölgenin koruma ve yenileme planları doğrultusunda yeniden ele alınması incelenmiştir. Bu planlar meydanın korunması ve meydanı tarifleyen değerlerin sürdürülebilirliği açısından ele alınmıştır. Özellikle alanda uygulanan güncel müdahalelerin 2008 yılında iptal edilmiş olan bir yenileme planıyla yüksek derecede olan benzerliği ve bu projelerin alanın kültürel miras özellikleri üzerindeki olumsuz etkileri detaylandırılarak tartışılmıştır.

Anahtar sözcükler: Tarihi kamusal açık alan, Kültürel miras, Kentsel koruma, Koruma amaçlı imar planı, Yenileme planı, Ulus Meydanı, Ankara

\section{Introduction}

Historic public open spaces of Ankara have developed a complex structuring over time and most of them embody the physical, socio-cultural, functional, ideological and visual values of different periods. Furthermore, while these open spaces have been, to a certain extent, able to maintain these essential attributes for centuries, recent political and economic demands have inevitably led these areas to transform into brand new urban spaces. Desultory interventions, insufficient master plans and inadequate conservation strategies specifically developed for public open spaces, have all had a devastating effect on features inherited from their past. Within this context, Ulus Square is a vulnerable example that is confronted by the gradual erosion of both its tangible and intangible values.

Ulus Square and its close vicinity has, since 2005, been part of a radical and irreversible transformation process of demolition, reconstruction and refunctioning activities. As well as the loss of the unique physical and functional aspects that identify Ulus Square, there is also a loss of the socio-cultural values attached to the area. It is clear that a systematic historic analysis should be conducted to preserve the cultural significance, authenticity and integrity of the square, as well as to develop coherent conservation principles to ensure the continuity of the values attached to the area. In this sense, the story of Ulus Square will subsequently be told to reveal the multilayered characteristics of the area, as well as its heritage value for Ankara.

\section{Emergence of Ulus Square: Transformation of an Empty Open Space into a Public Square ${ }^{1}$}

Although archaeological findings show that the surroundings of Ankara have been utilised from prehistoric times onwards, ${ }^{2}$ evidence obtained from the city centre indicate that the area has been intensively inhabited since

1 Starting from the Phrygian period onwards, several scholars mentioned the larger context of Ulus Square as an area being used for multiple purposes. On the other hand, there is insufficient information on the existence of a settlement, or the function and form of Ulus Square during Pre-Roman times. For this study, the Roman Galatian Period has therefore been chosen as the starting point for analysing the characteristics of the area before it became Ulus Square.

2 The tumuli found within the boundaries of today's Ankara province prove that the area was inhabited by many medium and small sized tribes in 3000 BC (Buluç, 1994, p. 21). 
the Phrygians. ${ }^{3}$ In addition, apart from negligible shrinkage during certain periods, the habitation area has been continuously expanding.

After the annexation of the city by the Romans in $25 \mathrm{BC}{ }^{4}$ the settlement began to expand towards the base of the Kale Hill. The area was typified by monumental buildings and open areas in parallel to "the Romanization politics that gives importance to architecture for constituting collective memory" (Güven, 2001, p. 112). As it was located at the junction of the Roman road network in Anatolia, Ankara became one of the most important centres of this peninsula of the Empire, from about 25 BC onwards (Akçura, 1971, p. 16). There is not sufficient information on the existence of a public open space during the Roman Galatian Period at the location of today's Ulus Square. On the other hand, considering the location of monumental buildings such as the Palatium, Nymphaeum and Julian Column, as well as public open spaces such as cardo maximus and agora (Kadıoğlu and Görkay, 2008, p. 151), it is a reasonable conjecture that the area which today is Ulus Square, was, by being part of an agora, used for commercial and social activities during the Roman Galatian Period. It is also possible, in terms of the location of a Palatium (palace) on the south of Ulus Square, to argue that the area was also used for administrative functions.

Between the Roman Galatian and Early Ottoman Period, there is no information on "Ulus Square" and its close vicinity. Starting from the Seljuks and Ahi Period, western parts of "Ulus Square" had witnessed the construction of several commercial and public buildings such as mosques, hammams and hans. Constructed in the $13^{\text {th }}$ century, Kuyulu Mosque (with its coffee house), Kizılbey Complex and Baklacı Baba Mosque are signs of public activities around the larger context of "Ulus Square" in that period (Figure 1A and 1B).

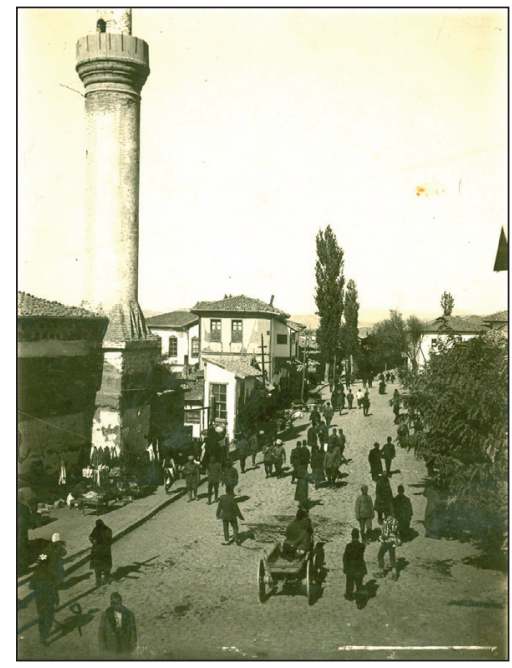

Figure 1A. Kuyulu Mosque, 1922. Source: VEKAM Library and Archive, Inventory no. 2711.

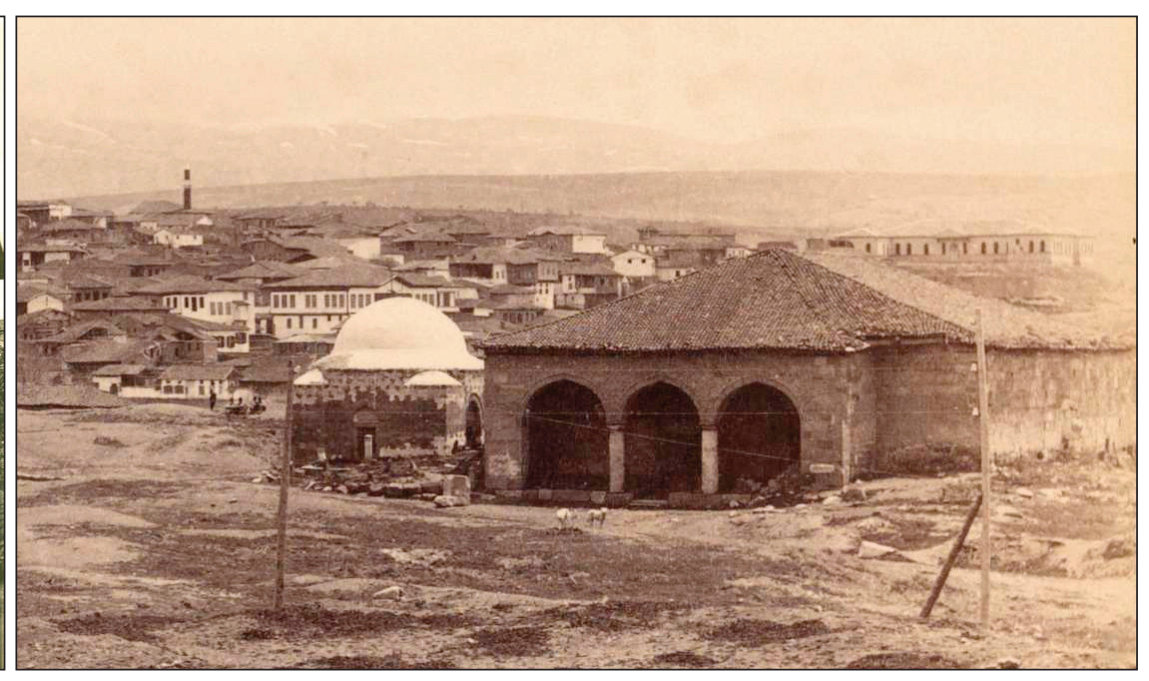

Figure 1B. Kizılbey Complex, a detailed view of the fourth part of Vue genérale de la Ville d'Angora [Panoramic view of Ankara].

Photograph by: Guillaume Gustave Berggren, Source: Université Bordeaux Montaigne, Fonds Paris, Série N / n²151 bis, 795196.

3 Some studies suggest that Ankara was a small-scale settlement in the Hittite Period. Nevertheless, due to the absence of archaeological data (Akurgal, 1994, p. 13) detailed studies of the city cannot be conducted.

4 Broughton states that Galatia became a part of the Roman Empire by 25 BC, but officially became a province in 20 BC (1938, p. 580).

5 Ulus Square is written within quotation marks to refer the open area where today's Ulus Square is located. 
In line with the rise of the Ottoman Empire, Ankara's most prosperous period was between the $15^{\text {th }}$ and the $16^{\text {th }}$ century, with its greatest success at the end of this period. Even though it used to be a fortified defence city, especially starting from the $16^{\text {th }}$ century, the city was internationally renowned on account of the fine mohair woven cloth of the area, known as sof, and which was produced from the hair of a special local goat, known as the tiftik keçisi or Angora goat (Faroqhi, 1985, p. 211). With local industry being concerned with sof production and its commerce, Ankara transformed itself into one of the most important commercial centres of not only the region, but also the empire (Figure 2A, 2B and 2C).

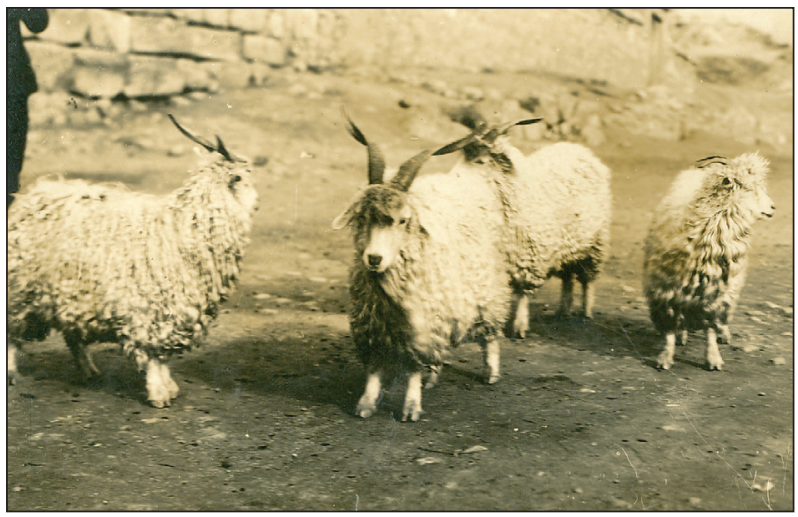

Figure 2A. Ankara Goat, 1920.

Source: VEKAM Library and Archive, Inventory no. 1550.
Along with the increase in economic welfare as a result of the commercial activities, the population also increased, and newly developed residential areas began to appear outside the citadel mainly surrounding the existing districts. Mosques, masjids and hamams were constructed according to the requirements of these new neighbourhoods. Moreover, the increase in sof production and commerce, which affected the level of wealth, also resulted with the emergence of new specialized commercial areas in the city. ${ }^{6}$ The city eventually gained a "double centred" (Ergenç, 1995, p. 16) structure, and these centres were named Yukarı Yüz [Upper Face] (around Mahmut Paşa Bedesteni) ${ }^{7}$ and Aşağı Yüz [Lower Face]

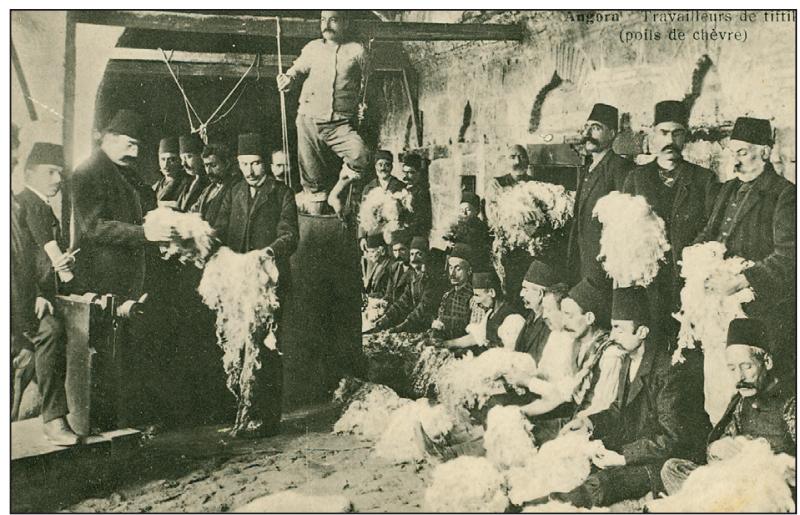

Figure 2B. Sof producers and merchants, 1905.

Source: VEKAM Library and Archive, Inventory no. 0763.

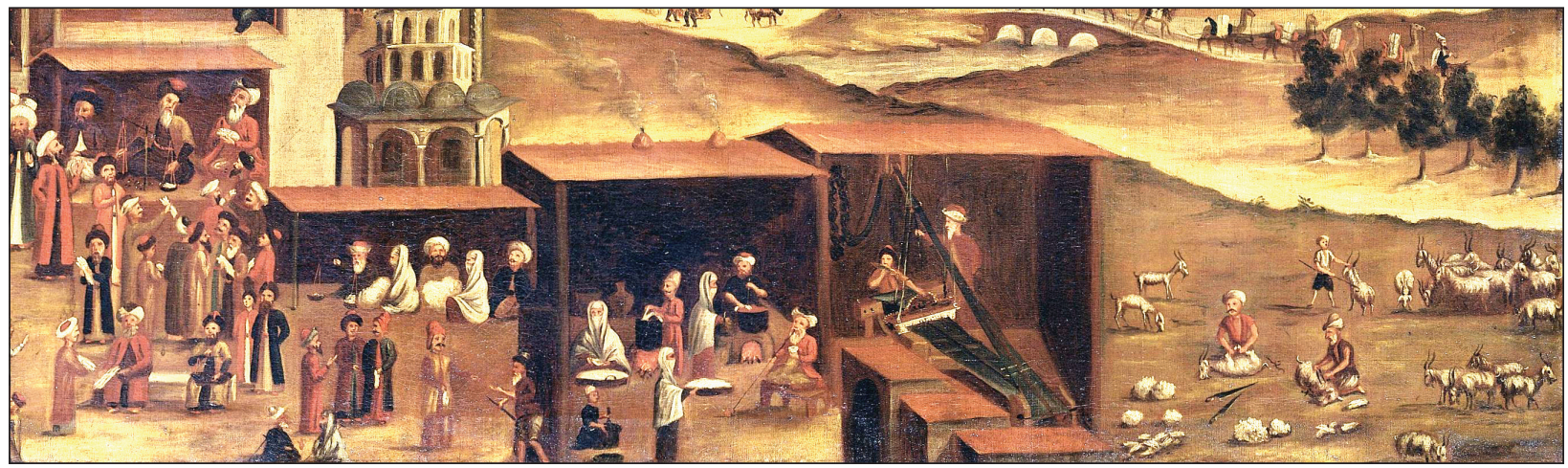

Figure 2C. A detailed view of the lower part of "View of Ankara", $18^{\text {th }}$ century: It can be clearly seen that the painter depicted Ankara by emphasizing sof production.

Source: Rijksmuseum, Inventory no. SK-A-2055.

6 According to Tahrir Defterleri [Ottoman Registries] of the $16^{\text {th }}$ century, Ankara was one of the wealthiest cities in Anatolia, and was continuously growing and developing (Tanyeli, 1987, p. 98).

7 The area covering Mahmut Pașa Bedesteni, Samanpazarı and Koyunpazarı environs was named as Yukarı Yüz. 
(around Tahtakale and Karaoğlan). ${ }^{8}$ Most importantly, these two main centres were connected to each other via Uzunçarşı [Long Market], a long and inclined commercial street (Figure 3A and 3B).

In additional to information related to the construction of monumental buildings, the only data available on "Ulus Square" in the $16^{\text {th }}$ century was on its utilisation as a part of Aşağ Yüz, one of the newly emerging commercial centres of Ottoman Ankara. In parallel with the transformation of the urban character of the city, open spaces around the lower parts, and especially the western and southwestern areas of Aşağı Yüz, began to be used for fields, cemeteries and short-term accommodation for foreigners visiting the city. For instance, Dernschwam mentioned in 1555 that, they stayed in a plain open space located in the lower parts of the city (1987, p. 257). Referring to this information, it can be stated that even though the surrounding areas of "Ulus Square" were mainly utilised for cemeteries, certain zones were used for temporary accommodation.

In the early $17^{\text {th }}$ century, Ankara witnessed a series of attacks led by irregular troops called Celali. These lead to most of the public buildings and commercial areas of the city, including Karaoğlan and Tahtakale, being

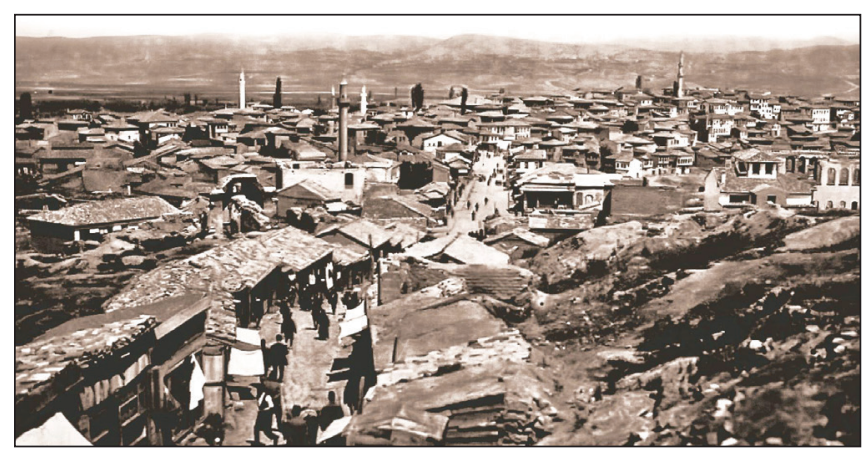

Figure 3A. Uzunçarş1.

Source: E. Tamur Archive, cited in Erdoğan, Günel and Narince, 2007, p. 48.

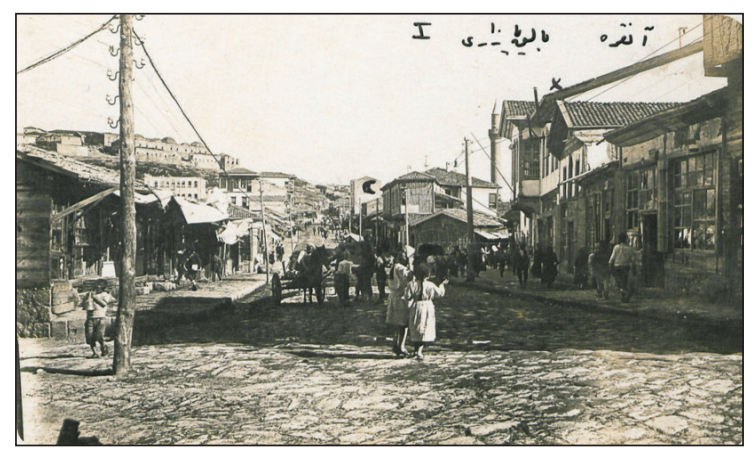

Figure 3B. Southern parts of Uzunçarş1.

Source: VEKAM Library and Archive, Inventory no. 0884.
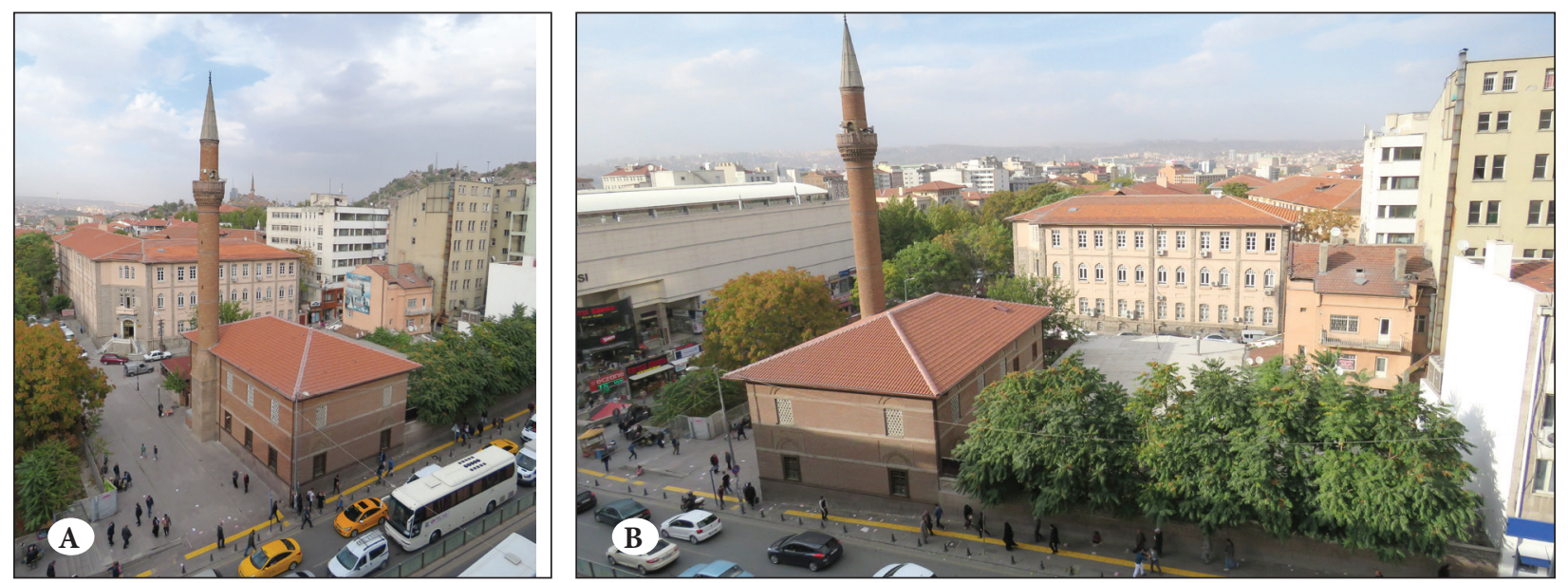

Figure 4A and 4B. Zincirli Mosque, 2017. Photograph by: Elif Selena Ayhan Koçyiğit.

8 Aşă̆ı Yüz covered an area between Hacıbayram Mosque and Karacabey Complex, western parts of today's Anafartalar Road. The centre of this area was constituted from the functionally specialized streets between Tahtakale/ Taht-el-Kala/ Kale altı-dibi where Hasan Paşa Hanı (Suluhan), Tahtakale Bath and Karaoğlan Çarşısı [Karaoğlan Bazaar] were located. 
burnt down. In order to prevent further destruction, construction of a third circuit of the city walls with several gates began in earnest. After the third circuit had been completed, most of the devastated areas including Karaoğlan, began to recover and several buildings, such as Zincirli Mosque (Figure 4A and 4B) were erected.

The third circuit had eight main gates, and several smaller ones, located in different parts of Ankara. Among these gates, İstanbul Gate was located just in front of "Ulus
Square" (Figure 5) ${ }^{9}$ and was one of the main gates of the city. In terms of İstanbul Gate's role and importance for the city, the area between Aşağı Yüz and the third circuit evolved into an open space that was mainly utilised by foreigners (especially the English, Dutch and French) for transportation, commercial activities and also for temporary accommodation. ${ }^{10}$

During the following century, Ankara continued to develop within the boundaries of the third circuit. ${ }^{11}$

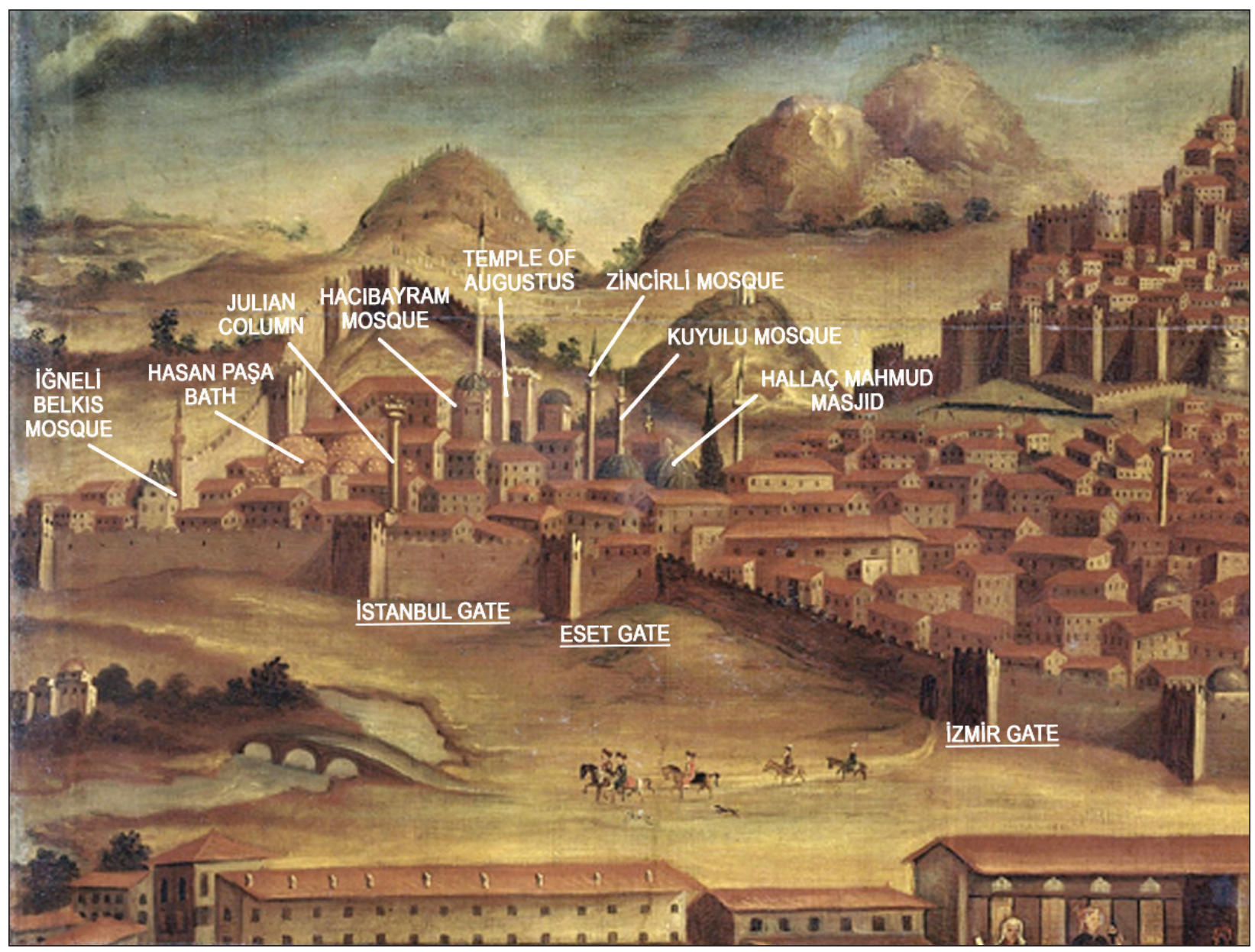

Figure 5. A detailed view of the upper left part of the "View of Ankara" painting, $18^{\text {th }}$ century: A detailed view of the east and northeast parts of the city.

Source: Labelled by the author on View of Ankara, Rijksmuseum, Inventory no. SK-A-2055.

9 The location of İstanbul Gate corresponds to an area that was the centre of the cemetery aligned with Millet Square (Mamboury, 1933/2014, p.86).

10 Evliya Çelebi, who visited the city in 1640 mentioned that the area between Aşağ 1 Yüz and third circuit of the city wall was mainly used by foreigners (especially by the English, Dutch and French) for commercial and residential purposes (1970, pp. 125-137).

11 During his visit to Ankara in 1703, Aubry de La Motraye mentioned in his notes that the city was surrounded by an irregular shaped city wall which was in a poor condition (1730, pp. 226-228). 
Although some parts of the wall were slightly demolished, it continued to be used until the end of the $18^{\text {th }}$ century. The data gathered from travellers' notes, such as Pitton de Tournefort (1717) and Paul Lucas (1712), as well as the court records and accounts of the construction of several public monumental buildings, all indicated an increase in commercial activities around Aşağı Yüz. As it was located between Karaoğlan and İstanbul Gate, "Ulus Square" and its close vicinity continued to function as a transition area between Aşağ 1 Yüz and the outer parts of the city, mainly being utilised by merchants for temporary accommodation, and it was also used as the site of an open bazaar.

The $19^{\text {th }}$ century marked a period of upheaval in the political, administrative and social aspects of Ottoman Empire, and this uncertainty was reflected in the emergence and use of urban space. In this respect, the city of Ankara, as with several other cities of the Ottoman Empire, was shaken by countless connected events. The notes of travellers such as Baptistin Poujoulat ${ }^{12}$ provide evidence that Ankara was experiencing economic problems during the first decades of the century. On the other hand, with the promulgation of the Tanzimat Reforms (1839-1876), new regulations on administrative and political issues, subsequently induced an era of transformation for Ankara and other Ottoman cities.

The period of Tanzimat officially began with Gülhane Hatt-ı Hümayunu [The Edict of Gülhane], which was issued in 1839. The reforms borrowed from the political conventions of Western republicanism and principally focused on renovation of the administrative apparatus. Even though Tanzimat was exclusively belonging to the bureaucratic elite in İstanbul, and thoroughly nurtured in the state-centred ideology of the Ottoman system (Keyder, 1987, p. 28), it was not long before the impact of the reforms were felt by the rest of the society, as well as other parts of the Ottoman Empire. Immediately following the promulgation of Tanzimat, Major Von Vincke visited Ankara in 1839 and produced two maps of the city (Figure 6A and 6B). The first map depicted Ankara and its surrounding region, while the other mainly focused on the city within the boundaries of the third circuit.

Of these maps, Plan der Stadt Angora is the first document that depicts Ankara with its topography, including cemeteries, waterways, city walls and gates, the castle, major roads and monumental buildings, most of which are labelled with their names. This plan is also the only document of the early $19^{\text {th }}$ century that clearly shows the spatial aspects and street pattern of "Ulus Square" and its close vicinity. It can be clearly seen in Von Vincke's map that a new square, named Hükümet Meydanı [Government Square (Hükümet Square)], and Tahtakale are depicted as open spaces, whereas there is no evidence of the existence of Ulus Square. It is important to highlight this as it shows that during the early periods of $19^{\text {th }}$ century, Tahtakale continued to function as a commercial public open space, while the formation of Hükümet Square had already begun with a small garden ${ }^{13}$ emerging in between surrounding governmental buildings. Furthermore, it can also be observed from the map that while the square was not yet fully formed, there are traces as paths of today's major roads and streets around "Ulus Square" (Figure 7).

In the following decades, the decline of commercial activities in the Yukarı Yüz region, as well as changes in the administrative structure of the Ottoman Empire, considerably accelerated the displacement of administrative areas from the Castle to the Aşağı Yüz region, where the new city was emerging. ${ }^{14}$ The area between İğneli Belkıs Mosque and Hasan Paşa Bath, an area close to Karaoğlan, was selected for the construction of administrative and military public buildings, such as Paşa Sarayı [Governor's Office] and Redif Kışlası [military barrack]. Although there is no specific information on

12 Poujoulat, who visited the city in 1837 , depicted Ankara by emphasizing its poor physical condition. He believed that Ankara was the most dispersed and neglected of all Turkish cities (1841).

13 There was a worn out, small memleket [hometown] garden in this square. This garden was described as being a puny greenery where destitute, homeless people, and some local tradesman, spent their time (Ortaylı cited in Yalım, 2001, p. 67).

14 Before the $19^{\text {th }}$ century, the governor of the city used to rent a house in the Yukar1 Yüz area and conduct administrative issues from that building. It was not therefore possible to see governmental houses in the Anatolian lands of the Ottoman Empire (Ortayl1, 1984, p.3). However, after 1839, following the Tanzimat Reforms, there was the need for a large/single building that could host all of the state officials in a hierarchical manner (Yalım, 2017, p.172). It was therefore necessary to transfer administrative functions from Yukarı Yüz to a new and empty area that could be utilised for the construction of new buildings that symbolised the modernisation of the period. 

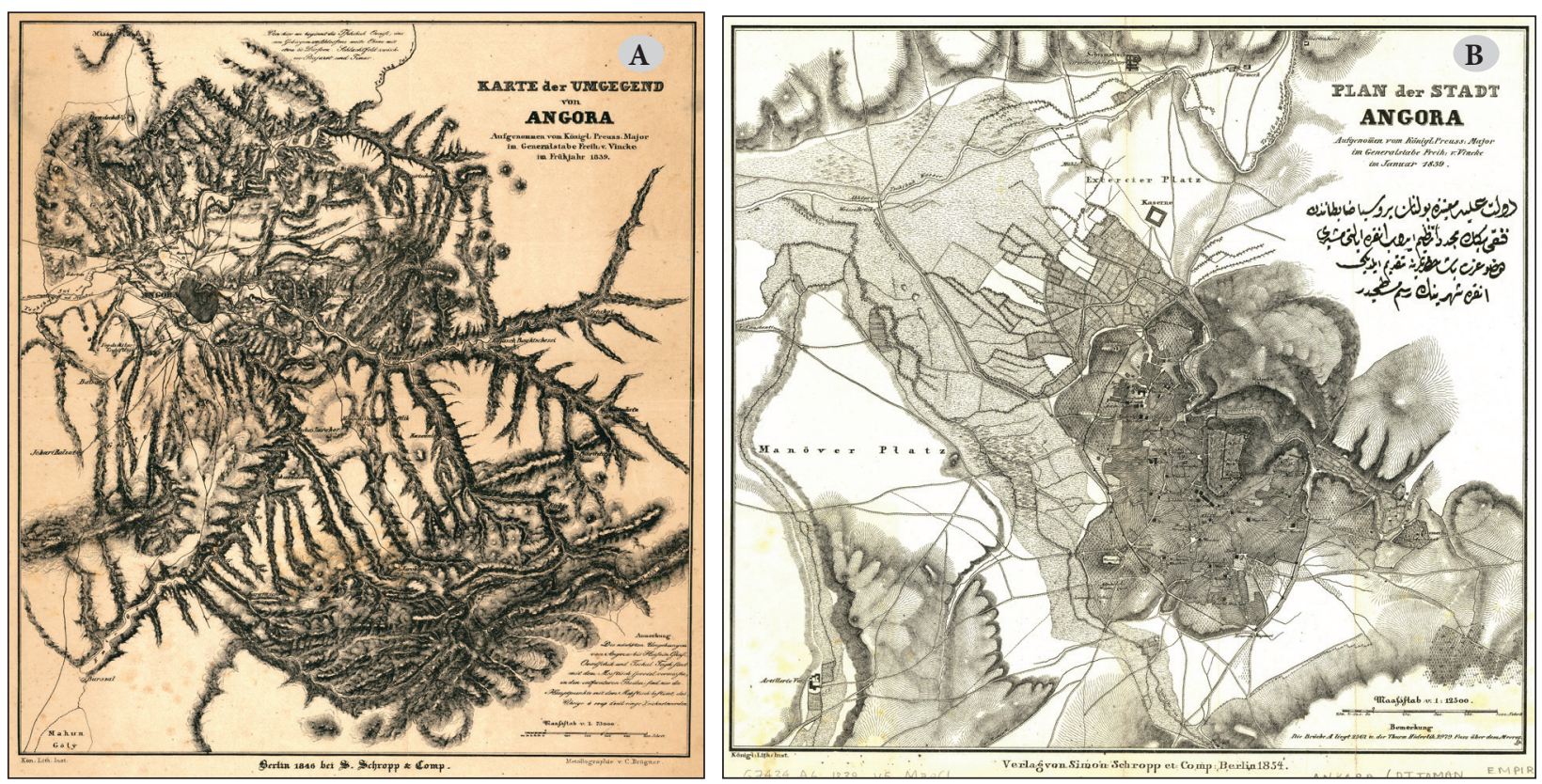

Figure 6. Maps of Ankara with different scales, prepared by Von Vincke, (1839).

A. Karte der Umgegend von Angora/ Map of the Neighborhood of Angora.

Source: Vincke, 1846.

B. Plan der Stadt Angora/ Plan of Angora City.

Source: Vincke, 1854.

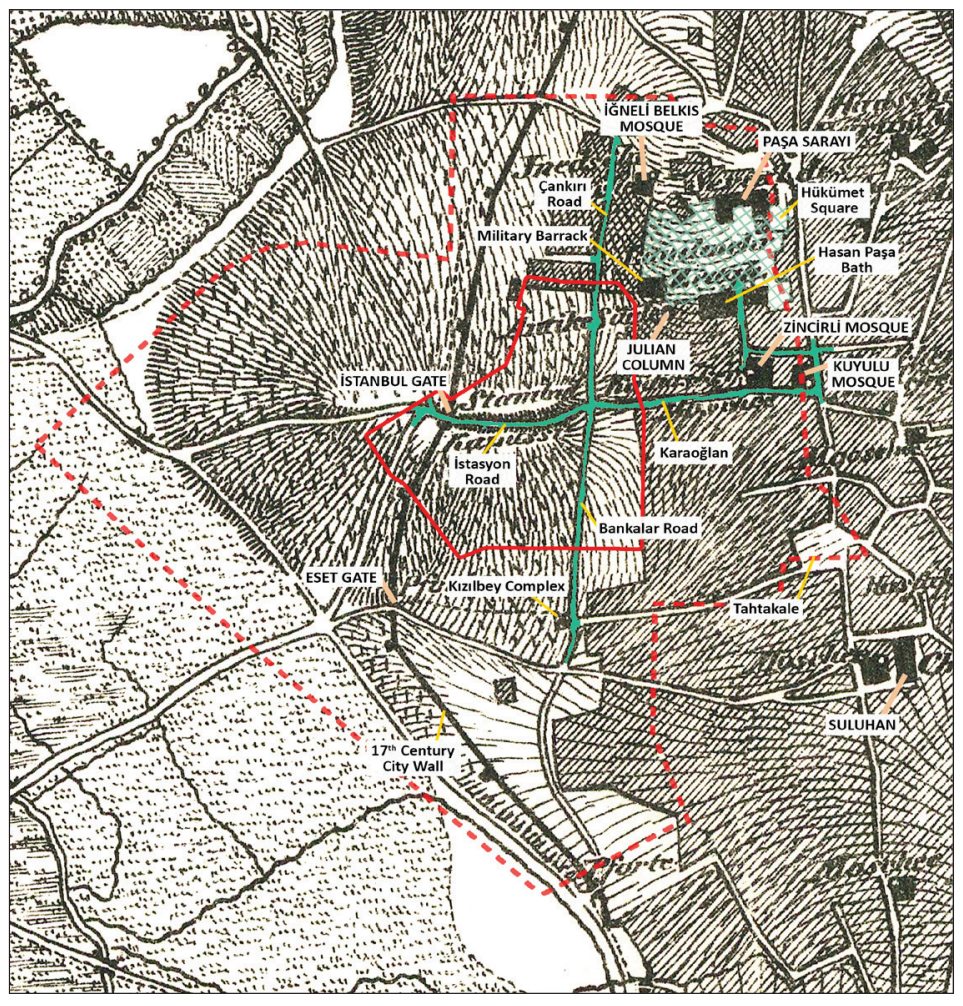

Figure 7. A partial view of Von Vincke's Plan of Angora, enlarged to provide a detailed view of Ulus Square and its close vicinity (Source: labelled by the Author on Von Vincke's Plan of Angora). Red Line represents Ulus Square, red dotted line represents Larger Context of Ulus Square, beige lines with capital letters show the monuments that are labelled by Von Vincke, orange lines are the remarks of the author, and blue lines are the traces of the roads, streets and the square that are still utilised today. 
their construction dates, it can be seen from Von Vincke's map that the formation of Hükümet Square had already begun by 1839 in between İğneli Belkıs Mosque, Paşa Saray1, the military barrack, Julian Column and Hasan Paşa Bath. The development of the square continued in subsequent years with the construction of other public buildings such as the Telgrafhane ${ }^{15}$ (Figure $8 \mathrm{~A}, 8 \mathrm{~B}$ and $8 \mathrm{C})$. Moreover, shortly after the declaration in 1882-1883 of Ankara as the administrative centre of Ankara Vilayeti [Ankara Province], with Çorum, Kayseri, Kırşehir and Yozgat falling under its jurisdiction, the number of daily visitors to the city for administrative purposes gradually increased, and Hükümet Square became one of the most crowded public open spaces of Ankara.

In addition to the shift of administrative functions from Ankara's Yukarı Yüz to Aşağı Yüz, the relocation of commercial activities also commenced during this period. In 1881, a fire in the commercial centre of Yukarı Yüz resulted in the partial demolishment of the most important commercial buildings of this region Mahmut Paşa Bedesteni and Kurşunlu Han. This event dramatically changed the characteristics of the Yukar1 Yüz region and, as a result, there was a slight shift in the activities around these buildings towards the Aşağı Yüz region. It can therefore be claimed that these incidents strengthened the vitality of commercial life in Karaoğlan and the surrounding areas.

The greatest number of physical changes in "Ulus Square" and its immediate surroundings took place during the last quarter of the $19^{\text {th }}$ century. As previously mentioned, "Ulus Square" was mainly used for temporary accommodation by merchants visiting Ankara. In proportion to the increase in administrative and commercial activities in the last quarter of the $19^{\text {th }}$ century, the number of daily visitors also increased and there was a corresponding need for short-term accommodation. In response to this need, a han with rooms for accommodation, called Taşhan [stone han], was constructed on the land located at the end of Karaoğlan (at the location of today's Sümerbank) in 1888 (Tunçer, 2001, pp. 61-62 and Sarıoglu, 1995, p. 185) (Figure 9A, 9B and 9C).

The emergence of the square that had begun with the opening of Tasshan was accelerated by the construction of a railway between İstanbul and Ankara (Ortaylı,

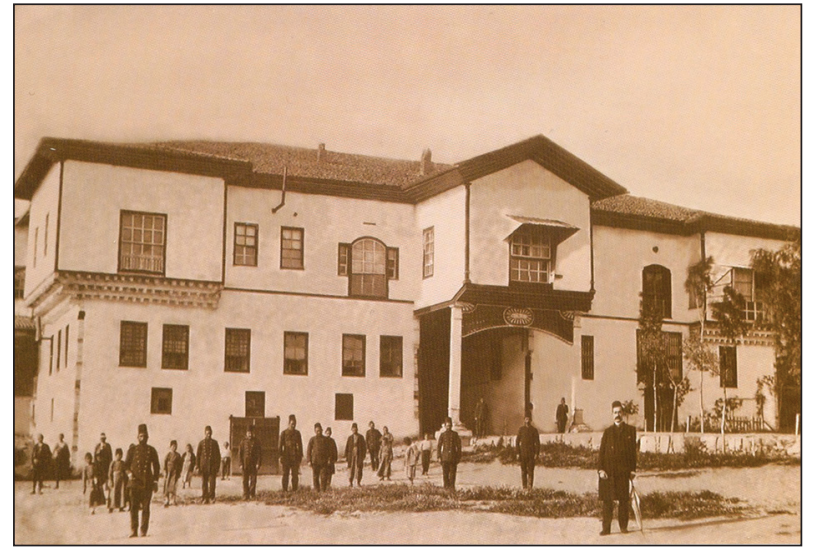

Figure 8A. The second building of Paşa Sarayı, late $19^{\text {th }}$ century.

Source: Aktürk, 2006, p. 2.

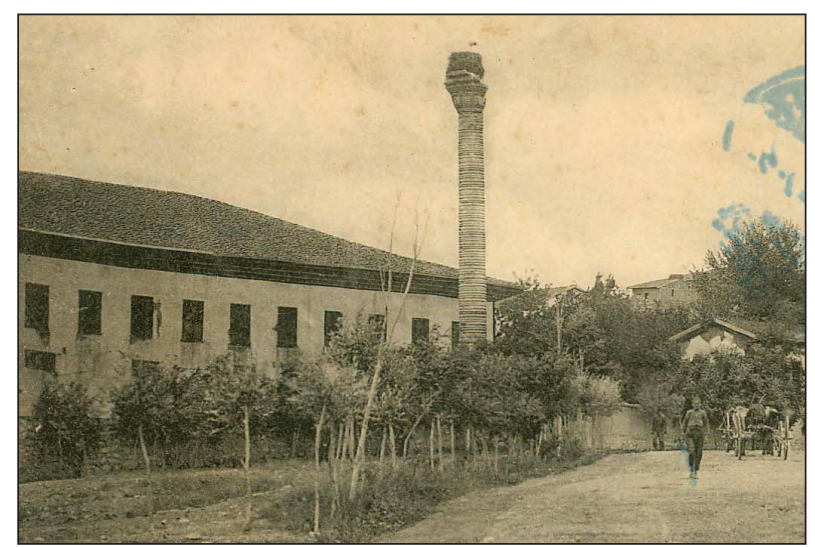

Figure 8B. Military Barrack and Julian Column in the front, 1905.

Source: VEKAM Library and Archive, Inventory no. 0071.

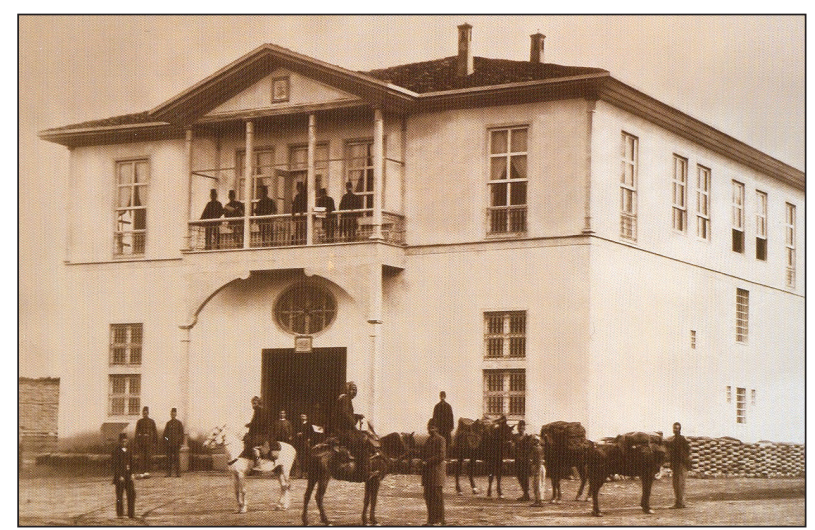

Figure 8C. The Telgrafhane, late $19^{\text {th }}$ century. Source: Aktürk, 2006, p. 4.

15 Even though the Telgrafhane is not labelled as a monument on Von Vincke's map of 1839, its location on the west of Paşa Sarayı is labelled in a different hatch. 


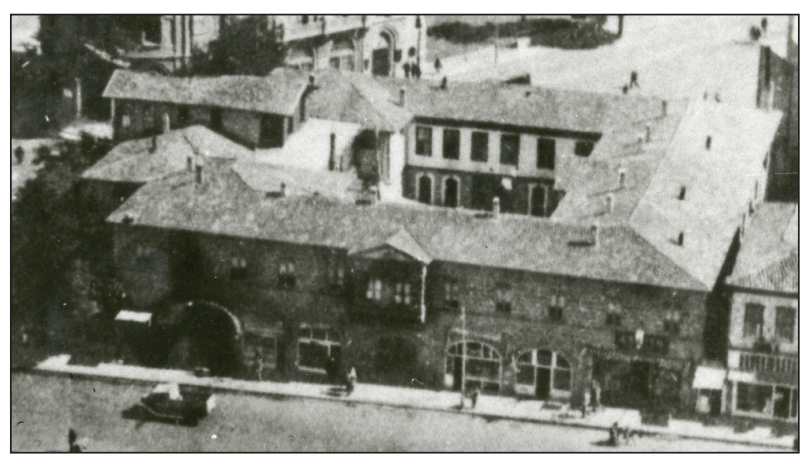

Figure 9A. Taşhan, 1931.

Source: VEKAM Library and Archive, Inventory no. 1687.

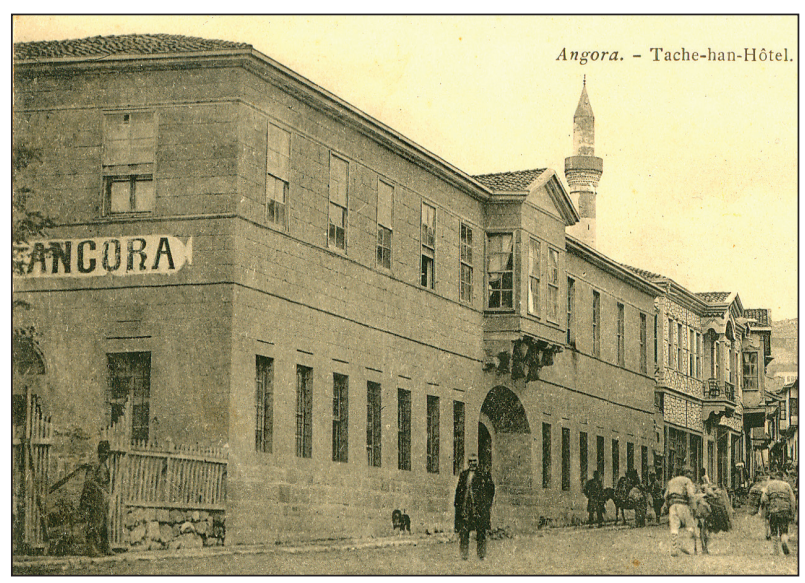

Figure 9B. Taşhan at Karaoğlan, 1890's.

Source: VEKAM Library and Archive, Inventory no. 0975.

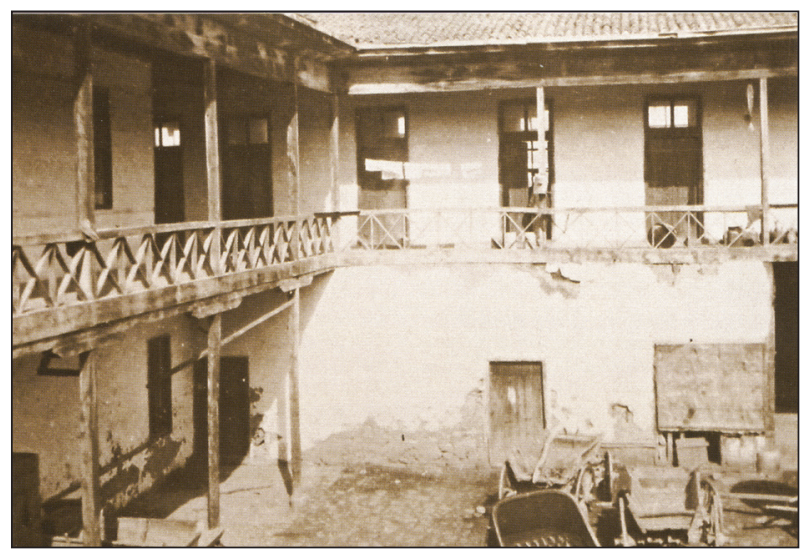

Figure 9C. Courtyard of Taşhan, 1921.

Source: Streit, 2011, p. 55.

16 A teachers' training school for secondary education.
2000 , p. 210). In 1892 , a train station was opened in the southwestern part of historic Ankara in the direction of the İstanbul Gate. The opening of the train station allowed cheaper and faster transportation of goods, and this resulted in changes both in the structure of urban facilities and also in the spatial organisation of the city (Tekeli, 1994, pp. 175-176). This event was marked by the revival of commercial activities in Aşağı Yüz, especially around Karaoğlan. Due to the fact that the area between the train station and Taşhan was a huge empty lot filled with cemeteries, the first area visitors of Ankara encountered when approaching the city from the direction of the train station was the open space in front of Taşhan. By being a significant building for its time, Taşhan provided an impressive welcome for the passengers coming to Ankara, both with its appearance and with its accommodation facilities (Yalım, 2001, p. 70).

Due to the opening of the train station, most of the buildings located at Karaoğlan and "Ulus Square", which had been previously used for agricultural commerce and storage, began to be replaced with modern shops, cafes, restaurants and hotels. Between 1892 and 1899, several hans were constructed in Ankara, especially around Karaoğlan. Şakir Bey Hanı and Kayseri Han were two of the most important of these hans, and were constructed next to Taşhan as attached buildings. At around this time, the idea of implementing a Millet Bahçesi [Nation Garden (Millet Garden)] in Ankara began to be considered. This was in line with the modernisation movement that had been developed in Europe and had spread to Ankara via other Ottoman cities. In 1895, the area called Beylik located on the northeast of İstasyon Road (where 100. Yil Çarşıst is located today) was chosen as the site of the first green public open space of Ankara. As well as green areas, the garden also featured a central pool and represented an oasis for Ankara residents (Memlük, 2009, p. 73). Immediately following the construction of the garden, Darülmuallimin ${ }^{16}$, the second monumental building defining the boundary of Ulus Square, was erected on the southern part of the square (Figure 10A). It was also in this period that the tiny paths depicted in Von Vincke's 1839 map evolved into one of the main axes of Ankara, and began to be known as Kizllbey Road (Figure 10B). As a result, even if the space surrounding Taşhan did not have the spatial aspects of an urban square, by the end of the $19^{\text {th }}$ century this small open space started to be known as Taşhan Square due to the increasing importance of its public functions. 


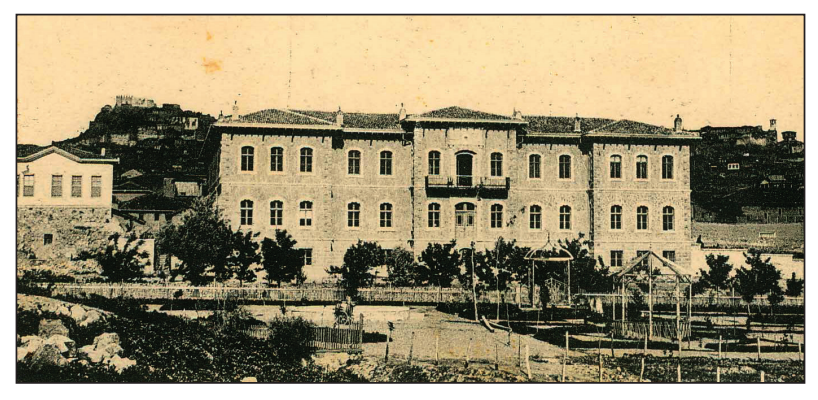

Figure 10A. Darülmuallimin and Millet Garden, 1901.

Source: VEKAM Library and Archive, Inventory no. ACF0037.

To summarise, the effect of the Tanzimat Reforms during this period led to a conscious intention to extend the city beyond its boundaries for the sake of 'modernisation', and the new institutional buildings and roads were all reflections of this ideology (Yalım, 2001, p. 82). As aspects of this development, the paths that crossed at "Ulus Square" had been transformed into more definite streets and roads, the first green area of Ankara was implemented, major roads were widened, paved and planted with trees, and several monumental buildings were constructed within "Ulus Square" and its environs. Even though Tahtakale and its surrounding areas continued to house commercial activities, Karaoğlan and Ulus Square were transformed into the main commercial and leisure centres of Ankara. Most important of all, two urban squares emerged: Hükümet Square and Taşhan Square.

\section{From Taşhan to Hakimiyet-i Milliye, Millet and Ulus Square}

At the beginning of the $20^{\text {th }}$ century, the negative impacts of political and economic problems were being felt in every part of the Ottoman Empire. After the collapse of local industry and artisanry in the face of Western competition during the $19^{\text {th }}$ century, the early $20^{\text {th }}$ century saw increasing foreign debts, financial bankruptcy and the European seizure of Ottoman revenues. All of these events were a precursor to a loss of political independence and the onset of seemingly perpetual wars with purposes that were often unknown but with apparently certain conclusions (Timur, 1987, p. 9). This was an agonising period for the Empire that left most of its cities and villages

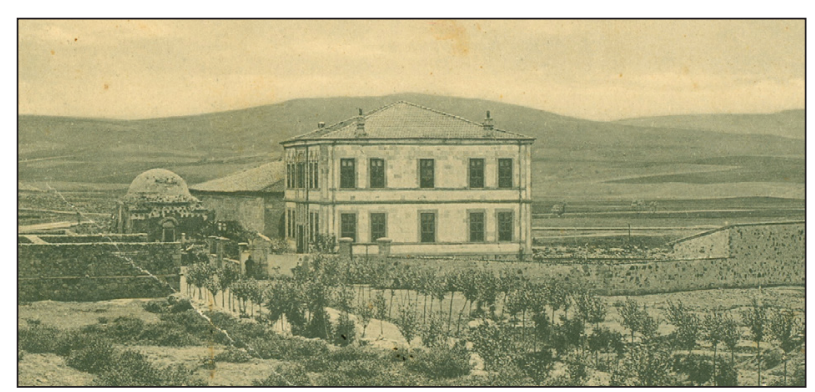

Figure 10B. Kizllbey Road increased its importance within Ankara and was accordingly planted with trees.

Source: VEKAM Library and Archive, Inventory no. 2439.

in a poor physical condition. The problems of the Empire accelerated the decline of Ankara, the administrative centre of Ankara Province, that had already begun in Yukarı Yüz during the $19^{\text {th }}$ century. Ahmet Şerif, who was a journalist for Tanin Gazetesi [Reverberation Newspaper] visited Ankara in November 1909, and described the city as being like a big village with full of mediocre houses and monumental buildings. He also mentioned that most of the shops opened late in the morning and closed again with the evening azan [prayer] (1977, pp. 91-96).

Compared to the rest of the city, Taşhan Square, Karaoğlan and Hükümet Square continued to function with only slight deterioration. Fuat Börekçi ${ }^{17}$, who was a child in the early $20^{\text {th }}$ century, described Taşhan as being one of the most important business districts of Ankara during that period. He also added that visitors from other cities would first stop at Taşhan and then continue on to Karaoğlan, Atpazarı, Samanpazarı and Saraçlar (cited in Bağlum, 1992, p. 36). Additionally, according to the memoirs of Vehbi Koç, before the First World War whenever the governor left the Vilayet [governors' office] and walked through the main commercial street, presumably Karaoğlan, people used to gather along the street to salute him $(1983$, p. 9). It can be seen from this insight that it was a lively area utilised both by the most important figures of the period and also by the public.

In parallel to these events, Vali Reşit Bey, who was the governor of Ankara during the early periods of the $20^{\text {th }}$ century, realised the importance of Taşhan Square as being the main entrance to the city from the train station. He therefore decided in 1911-1912 to organize the space

17 The lawyer, Fuat Börekçi, was the son of Rıfat Börekçi (mufti of Ankara), and a member of one of the most well-known families of Ankara, Börekçizade. He was born in Ankara in 1911. 
and improve its physical conditions. As part of this reform, the boundaries of Taşhan Square were enlarged, and this change provided impetus to a series of stupendous events that occurred in the area. Among these, the most significant was the construction of a building for the Ittihat ve Terakki Cemiyeti [The Committee of Union and Progress] in 1915-1916 (Figure 11). This was a modest building constructed in an area, previously used as a cemetery, that was located at the end of İstasyon Road to the west of Taşhan. ${ }^{18}$ With the construction of this building, Taşhan Square's western edge became clearer and it gained a more definite form. On the other hand, the İttihat ve Terakki Cemiyeti building had not just a contemporary architectural impact, but also a significant impact on the daily life of the square.

Another important building of early $19^{\text {th }}$ century Ankara was a bar named Fresko/ Fresco which was located in the southern section of Millet Garden (Tanyer, cited in Gülekli and Onaran, 1973, p. 169). Even though a gazino, renovated from Mustafa Tevfik Efendi Hanı, and a clubhouse on the top floor of Düyun-u Umumiye/ Reji [Public Debt] were already frequented by men for entertainment purposes and were increasing the daytime usage of the area, the opening of Fresco meant that Taşhan Square and its close vicinity also became busier at night time. ${ }^{19}$

From the 1910s onwards, the physical, functional and visual aspects of Taşhan Square, as well as its meaning started a gradual process of transformation. While

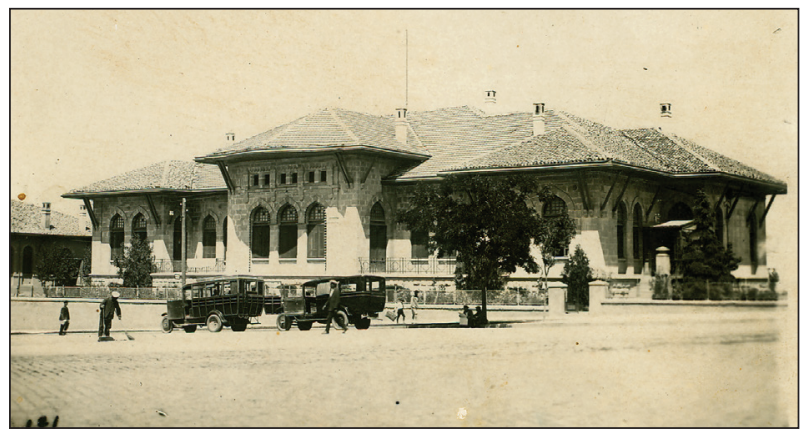

Figure 11. The İttihat ve Terakki Cemiyeti building. Source: VEKAM Library and Archive, Inventory no. 0820. residents had previously referred to this open space as a "square," it was difficult to define it as being a functioning urban square with a definite form and edge. However, after the interventions detailed above, Taşhan Square occupied a definite area that was determined by the İttihat ve Terakki Cemiyeti building to the west, Millet Garden and Fresco to the south-west/south, Darülmuallimin to the east and Taşhan to the northeast (Figure 12). From this point onwards, it was easy to define the square as being a public open space with an irregular geometric form that was framed by monumental buildings and a public garden. Along with the widening of the space, and due to the function of the surrounding buildings, the daily usage of Taşhan Square increased. As a result, the square became one of the main public open spaces of the city, and was frequently utilised for meetings and gatherings.

In November 1918, Allied Troops (British, French and Italian) occupied İstanbul, the capital city of the Ottoman Empire, and set up a military administration. In response to the occupation, and also to resist the political and military dissolution of the Ottoman Empire, a new

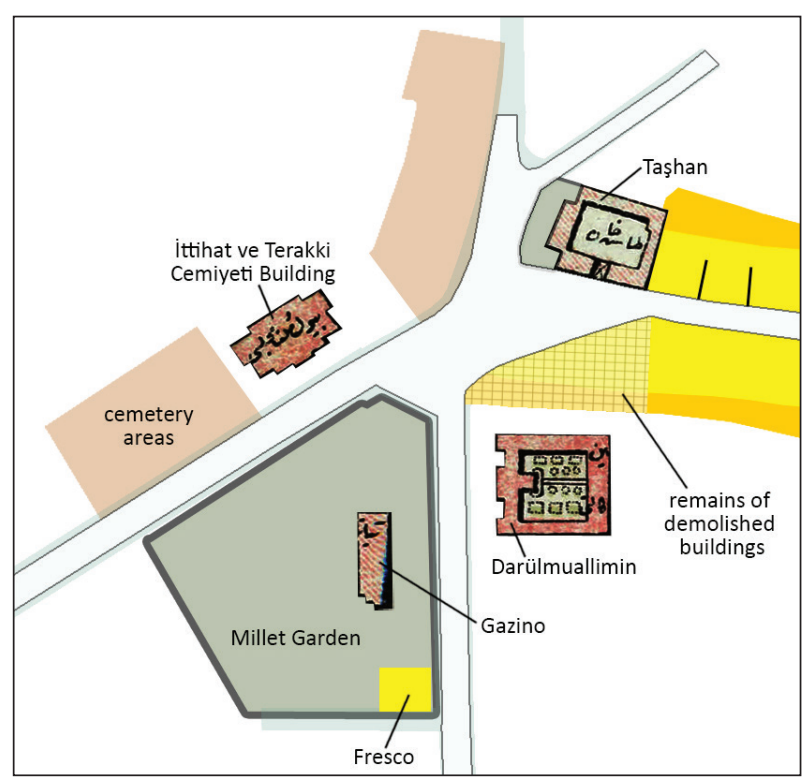

Figure 12. A schematic view of Taşhan Square, 1910.

Source: Elif Selena Ayhan Koçyiğit, drawings of monumental buildings are utilised from the 1924 Ankara City Map, VEKAM Library and Archive, Inventory no. H004.

18 Before the construction of this building, a cottage owned by a dervish stood at the site. A dervish collected money from foreigners that entered the city from İstasyon Road (Şapolyo, 1969, pp. 6-7).

19 Vali Reşit Bey’s idea of installing kerosene lamps in Millet Garden also contributed to this increase. 
organisation called Kuva-yi Milliye [The National Forces] was established in May 1919. Representatives from each province were selected, and under the guidance of the group's primary spokesperson, Mustafa Kemal, a series of meetings were held in different parts of the country. Meanwhile, supporters of Kuva-yi Milliye organised gatherings and celebrations in cities nationwide. Of these cities, Ankara was one of the most prominent in terms of public support. It was because of the level of support, and other critical reasons ${ }^{20}$, that Mustafa Kemal arrived in Ankara on 27 December 1919 and announced that the city would be the operational centre of the movement (Figure 13A and 13B).

At the beginning of 1920, the Ottoman Empire had entered a period of dissolution due to enormous casualties and defeat in the First World War. During this difficult period of limited resources, Mustafa Kemal and the Representative Committee were struggling to establish a national assembly in Ankara that was independent and separate from İstanbul. Achievement of this goal became particularly important after the occupation of İstanbul by the Allied Forces, and the quashing of Meclisi-i Mebusan [The Chamber of Deputies] on the 28 January 1920. Therefore, due to the sense of urgency and limited available funds, the İttihat ve Terakki Cemiyeti building was selected as the most appropriate site (in terms of its location and the physical aspects) for the base of the new assembly. On the 23 April 1920, the National Assembly was finally opened (Figure 14), and Ankara became the centre of the War of Independence. The National Assem-

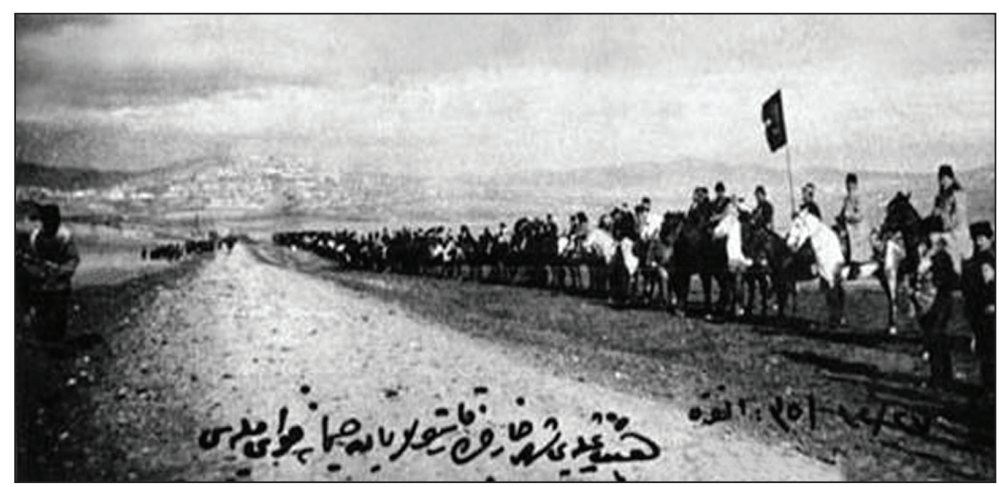

Figure 13A. Seymenler waiting for Mustafa Kemal at Yenişehir. Source: A. Müderrisoğlu Archive, cited in Erdoğan and Günel, 2007, p. 109.

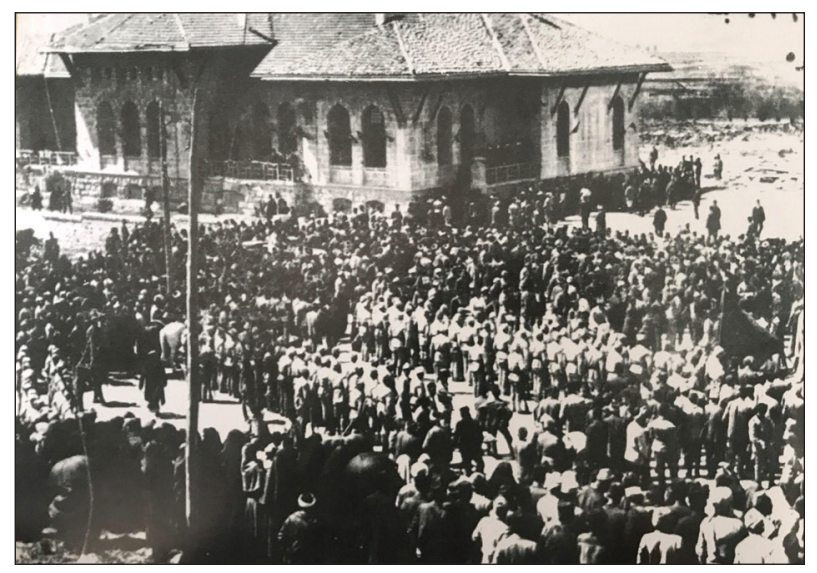

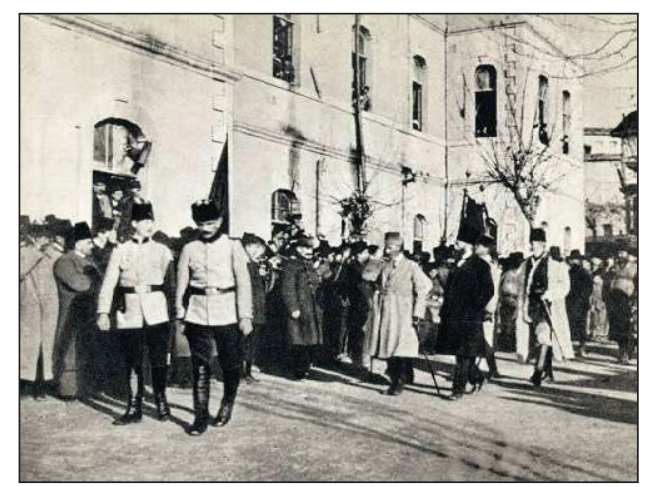

Figure 13B. The arrival of Mustafa Kemal and the Representative Committee at Hükümet Square. Source: Erdoğan and Günel, 2007, p. 117.
Figure 14. The opening ceremony of the National Assembly, 1920. Source: Özel, 2001, p. 26.

20 There are several reasons behind Ankara being selected as the operational centre of the Kuva-yi Milliye movement. These included the city being geographically located in the centre of the country, easy to defend from military attacks, connected to different parts of the country by train, and most importantly, having the complete support of the people of Ankara. For detailed information, see Tekeli (2000, pp. 318-321). 
bly became the main administrative building of the city, and most importantly, Taşhan Square became the main public open space of the city. Following the opening ceremony organized at this square, a significant precedent in Ankara had been established, and Taşhan Square had become the regular venue for open-air celebrations and meetings (Yalım, 2017, p. 177). Subsequently, in recognition of its importance and the role it played in the War of Independence, Taşhan Square was re-named by the state authorities as Hakimiyet-i Milliye [National Sovereignty].

Although Millet Garden became neglected, and its pre-war condition could not be preserved, the gazino and the Millet Garden gradually became more popular following the opening of the Assembly, and the garden subsequently became the main green open recreational space of Ankara. ${ }^{21}$ Furthermore, the construction of administrative buildings, as well as the regular opening of new shops, offices and restaurants (mainly at Karaoğlan and less on Mekteb-i Sanayi Road, previously known as Kızılbey Road and Çankırıkapı Road) also increased the popularity of Hakimiyet-i Milliye Square. During this period, the square acted as a stage and the people of Ankara as an audience. The bustle of the city could easily be observed from Hakimiyet-i Milliye Square with deputies, the governor, general commanders and soldiers, officers, judges, police officers, religious figures, journalists, foreign visitors and traders all running between İstasyon Road, Karaoğlan, and Hakimiyet-i Milliye Square. While these areas were popular, the main roads ${ }^{22}$ intersecting at Hakimiyet-i Milliye Square, as well as the square itself were in a miserable condition.

During the War of Independence between 1920 and 1923, Ankara was struggling with economic crises, construction activities were bogged down and not even a tree was planted in the city. Houses, monumental buildings and public open spaces were all in a poor physical condition. Ankara was looking shabbier than ever, partly due to several fires that had occurred at the beginning of the century. With the exception of some major roads, such as
Karaoğlan, İstasyon and Mekteb-i Sanayi that intersected at Hakimiyet-i Milliye Square, most of the streets were dusty, sinuous, irregular and very dark at nights. ${ }^{23}$ Falih Rufkı Atay described the physical condition of Ankara and his feelings about the city life at the time as follows:

I do not think that even a conservative village is as rudimentary as Ankara... The main commercial street is so rudimentary that it is hard to find a set of glasses, plates or cups to furnish a small table. When compared to Karaoğlan, Beyoğlu is like a boulevard in Paris... Since it is always the same people who walk around or meet either at the restaurant next to the National Assembly or in Millet Garden, we do not even bother to greet each other anymore. A common complaint is: "Ahh, if only we had the chance to be anonymous, to mingle in the crowd and get lost". Yet there is no other place other than the assembly to spend the daytime, while during the nights, we yearn for Mustafa Kemal to invite us... (2010, pp. 440-441).

Although the physical condition of Ankara and the pace of daily life did not impress newcomers during the War of Independence, the physical and social environment changed incredibly fast during the second half of 1923. This began on October $13^{\text {th }}$ when Ankara was declared as the capital city, which was followed by the declaration of the Republic of Turkey on October $29^{\text {th }}$. Following the declaration of the Republic, Ankara witnessed a rapid change in the population of civil servants and bureaucrats. This increase also affected the main character and social life of the city. Instead of being typified as a place of trade and production, the city now became the centre of administration.

It was the state's intention that life in the capital city should be of modern Westernized standards, and that the city should be a role model for Turkey (Tekeli, 2000, p. 325). Certain measures were accordingly taken, including the establishment of Ankara Şehremaneti [The Municipality of Ankara] in 1924, while Hakimiyet-i Milliye Square, the main public open space of Ankara, was cleared of dust

21 Ellison mentioned that she had the chance to visit the park with its beautiful flowers and listen to its band (1973, p.145). In addition, Şapolyo mentioned in his memoirs that, with its pool in the middle, Millet Garden was the only green area of Ankara (1967, p.170).

22 According to Ellison, Mustafa Kemal's car danced on Ankara's roads 'like Shakespeare's devils'. She believes that Mustafa Kemal's chauffeur had become skilled enough to easily drive in every country of the world (1973, p.136).

23 In his novel Ankara, Karaosmanoğlu depicted the darkness of the streets of Ankara at night as being pitch black and claimed that sometimes to be able to walk one had to use one's hands to navigate (2001, p.89). 
and paved with cobblestones. ${ }^{24}$ Additional buildings were also constructed at the square. The buildings labelled " $\mathrm{X}$ " on Figure 15 were constructed on the northern part

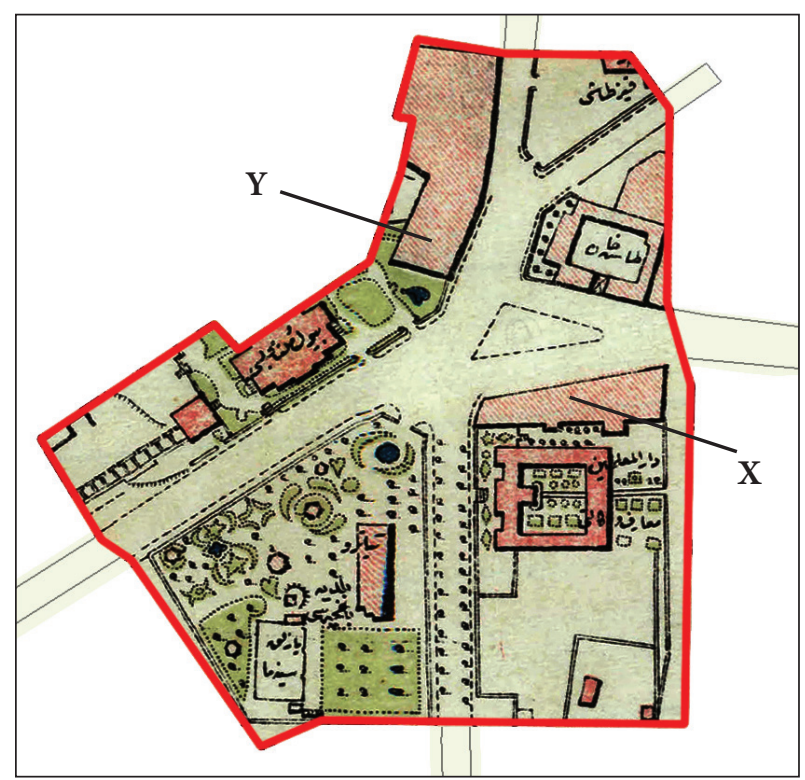

Figure 15. A partial view of 1924 Ankara City Map, Hakimiyet-i Milliye Square and its close vicinity; X: Attached small shops; Y: Burla Biraderler (one storey high-single building).

Source: Labelled by the author on Ankara City Map, VEKAM Library and Archive, Inventory no. H004.
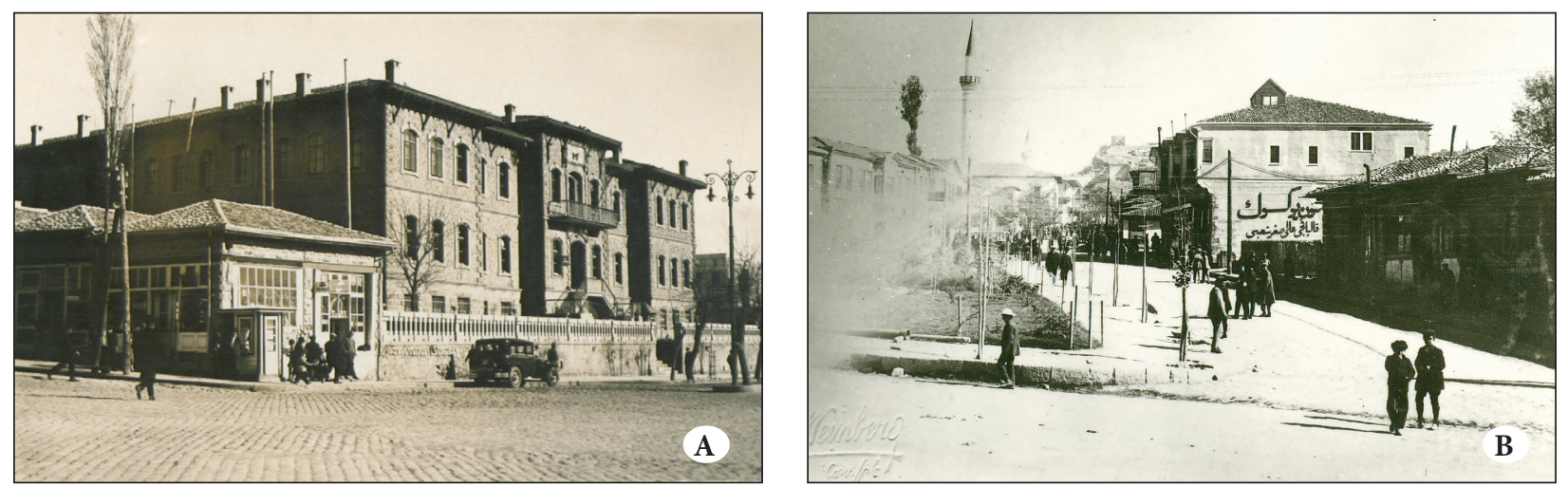

Figure 16. Small shops to the north of Darulmuallimin A. 1925 (Source: VEKAM Library and Archive, Inventory no. ACF0373), B.1925-1926 (Source: VEKAM Library and Archive, Inventory no. 0767).

24 For further details, see Tunçer (2001, p.81), Sarığlu (2001, p.47) and Şapolyo (1967, p.165).

25 The rapid transformation of Ankara also attracted the attention of journalists from London. On 22 December 1924 , an article was published in The Times entitled "A Turkish Capital”, which described the major urban activities in Ankara (Şimşir, 2006, p.368). 
Between 1924 and 1929, several administrative, commercial and financial buildings, as well as public green open spaces, were constructed around Hakimiyet-i Milliye Square and its close vicinity. ${ }^{26}$ In additional to construction activities, there was also a great interest in widening/ improving of existing roads, the opening of new ones and the renaming of these roads/streets for ideological purposes. The main roads of Ankara such as
Çankırı Road, Karaoğlan Road ${ }^{27}$, İstasyon Road ${ }^{28}$ (Figure $18 \mathrm{~A}$ and 18B) and Büyük Millet Meclisi Road were all widened, paved and planted with trees (Cengizkan, 2004, pp. 52, 59).

As a result of urban activities, such as the opening of new roads and the improving existing ones, several districts became more permeable and accessible. The better constructed roads meant that the use of motor vehicles be-

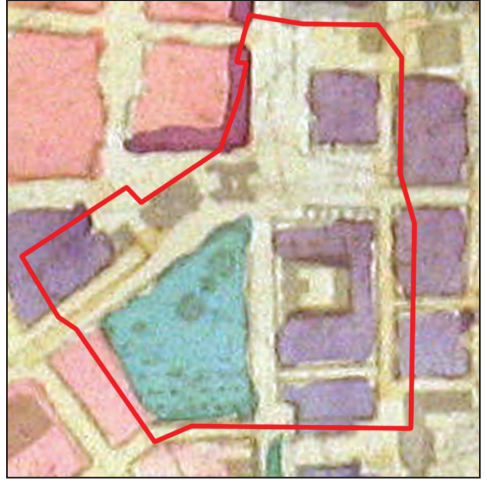

Figure 17A. A detailed view of Hakimiyet-i Milliye Square in Lörcher's Ankara plan.

Source: Labelled by the author on Lörcher's Plan, Goethe Institute.

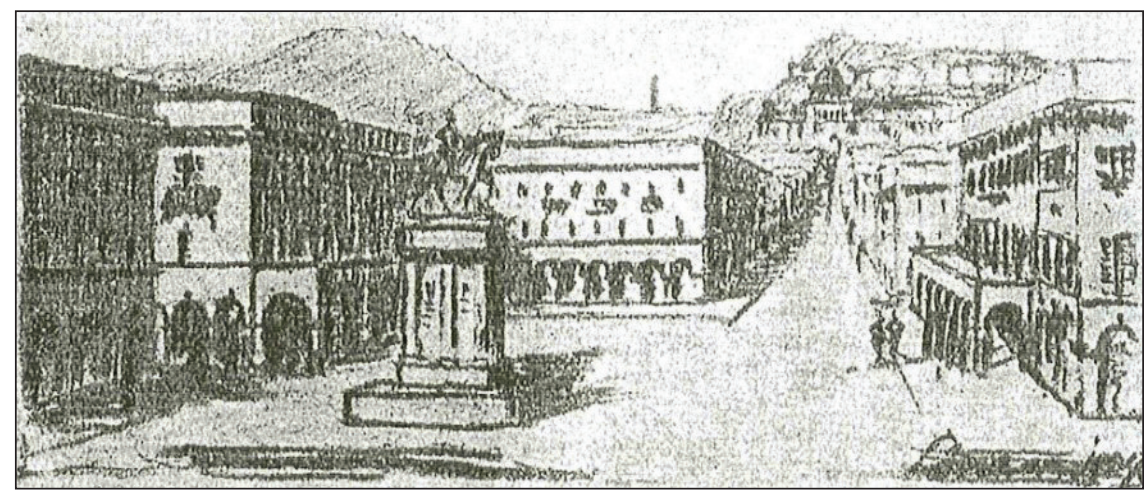

Figure 17B. Lörcher's perspective drawing of Hakimiyet-i Milliye Square, 1924-1925. Source: Cengizkan, 2004, p. 64.
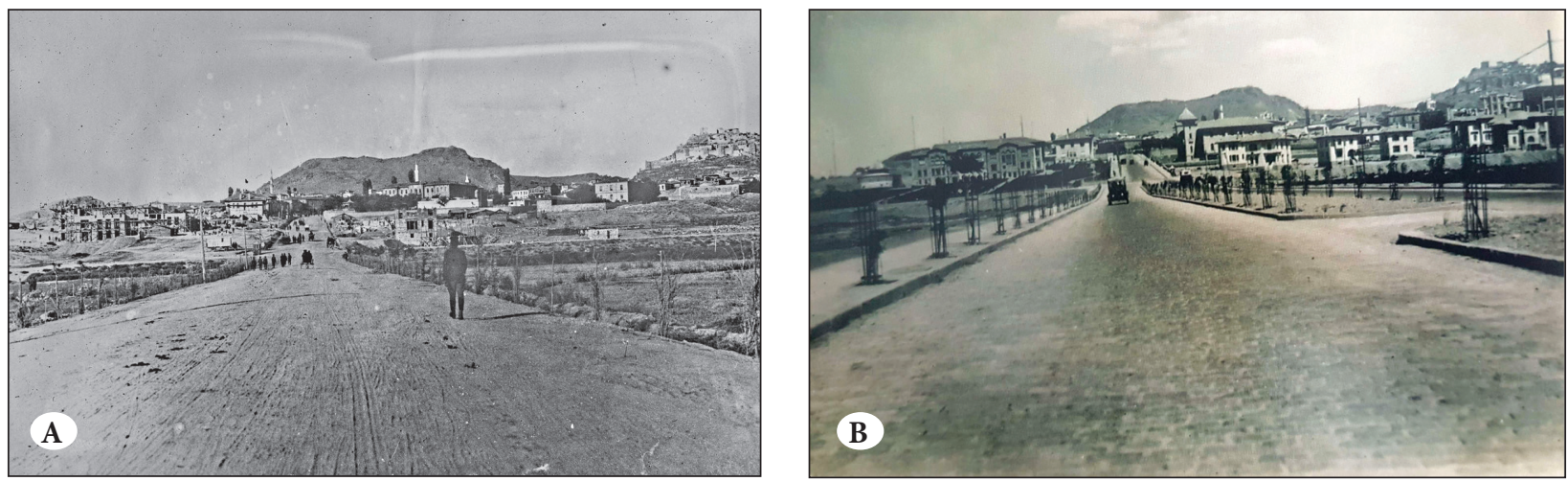

Figure 18. Transformation of İstasyon Road A. Before the road works, early 1920s (Source: Bibliothèque Nationale de France, Identifier: ark:/12148/btv1b53119802t). B. After the road works, 1930 (Source: Cang1r, 2007, p. 1043).

26 The $2^{\text {nd }}$ National Assembly (1924), Divan-ı Muhasebat [Court of Accounts] (1925) and Ankara Palas (1927) on Büyük Millet Meclisi Road, Posta ve Telgraf Umum Müdürlüğü (PTT) [General Directorate of Post and Telegraph] (1925), Lozan Palas (1926), Tekel Baş Müdürlüğü [General Directorate of The State Monopolies] (1928), Osmanl Bankası [Ottoman Bank] (1926) and Ziraat Bankası [Agricultural Bank] (1929) on Mekteb-i Sanayi Road, Maliye Vekaleti [Ministry of Finance] (1925) at Hükümet Square and its terraced garden on the west/ back, and İş Bankası [Business Bank] (1929) on Çankırı Road, close to the north of Taşhan.

27 Koç mentioned that one of the houses that was demolished during the widening of Karaoğlan Road was their home which had a shop on the ground floor. Therefore, they constructed a new building called Koç Han to the northeast of the National Assembly (1983, pp. 33-35).

28 İstasyon Meydam [Station Square] (the open area in front of the entrance to the station) was also reorganized and paved with cobblestones in 1928 (50 Yıllık Yaşantımız, 1975, p.42). 
came much easier. Therefore, in addition to private cars, the first buses, called Kaptıkaçt ${ }^{29}$ were introduced. They were managed by private companies or individuals, and operated on the main roads along with another type of bus $^{30}$, managed by Imalat- $\iota$ Harbiye (Figure 19A and 19B). As part of this new system, Hakimiyet-i Milliye Square was chosen as the central location for several bus stops.

The state authorities were aware of the importance of Hakimiyet-i Milliye Square for the city and were therefore extremely keen on improving the square to represent and promote the ideology of the state. The newly established

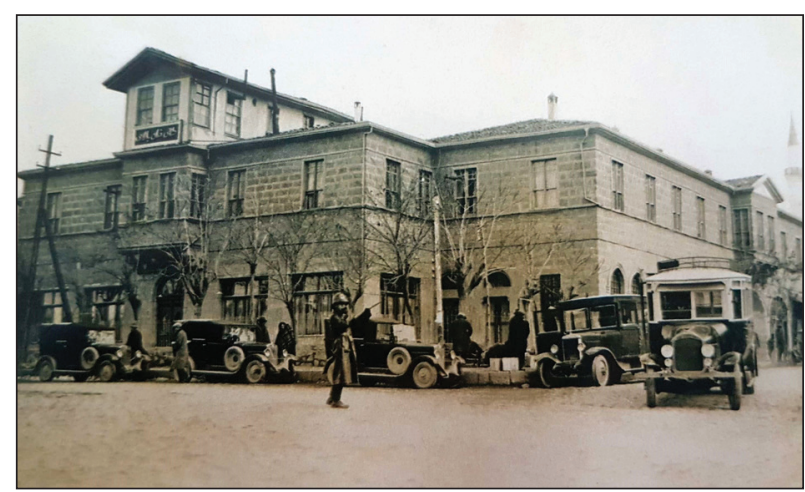

Figure 19A. Kaptıkaçtı in front of Taşhan, 1927.

Source: Cangir, 2007, p. 1073.

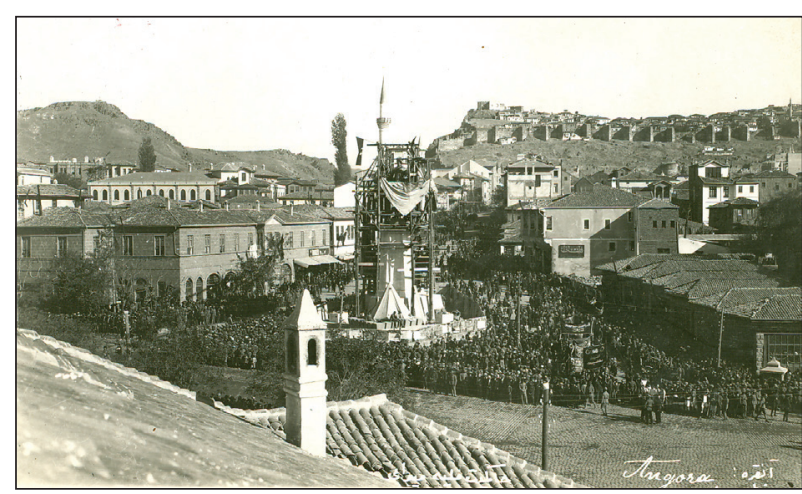

Figure 20A. Opening ceremony of the monument, 1927. Source: VEKAM Library and Archive, Inventory no. 0931. nation-state therefore tried to create a new identity for the square that would reveal a collective memory through the daily practices (Yalım, 2017, p. 158). In order to do this, authorities invited an Austrian sculptor, Heinrich Krippel, to design a monument. His monument Zafer (Atatürk) Anıtı [The Victory Monument] was erected at the centre of the square and unveiled during an opening ceremony on 24 November 1927 (Cengizkan, 2004, p. 64) (Figure 20A and 20B). The square subsequently began to be referred both as Zafer Meydanı [The Victory Square] and Millet Meydanı [Nation Square (Millet Square)]. ${ }^{31}$

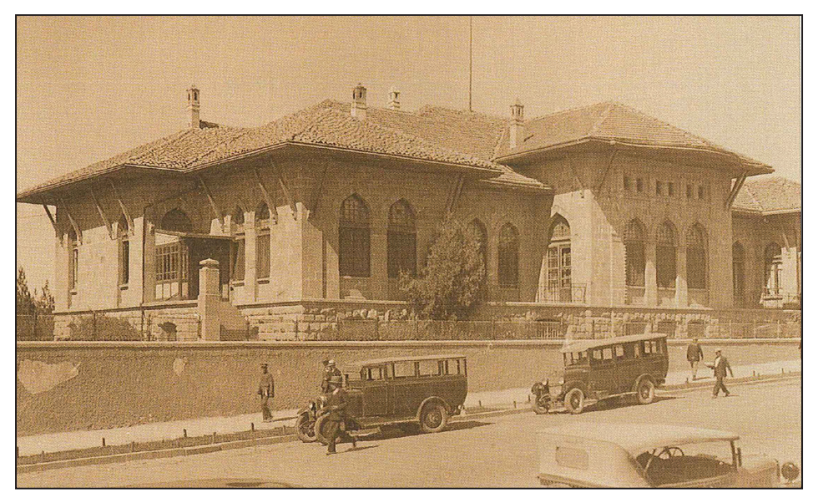

Figure 19B. Kaptıkaçtı in front of the First National Assembly, 1928.

Source: Önen, 2004, p. 22.

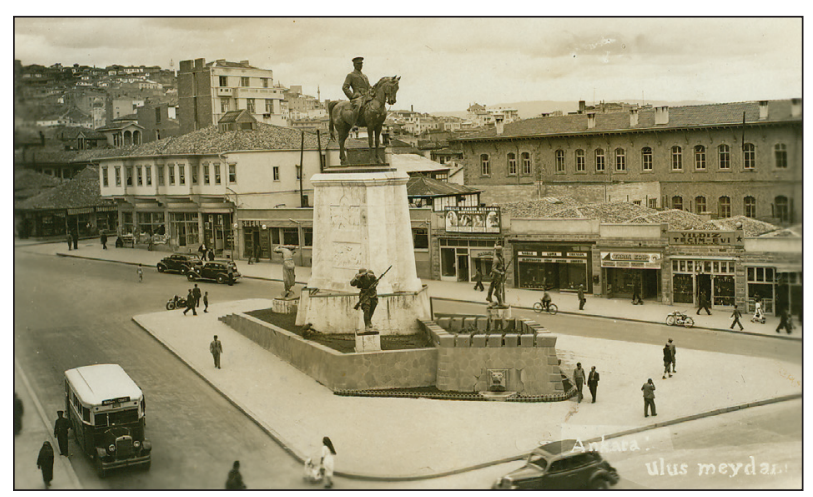

Figure 20B. Victory Monument and its immediate surroundings, 1929.

Source: VEKAM Library and Archive, Inventory no. 0990.

29 They were grey and carried up to five, six or eight people (Makaracı cited in Ergir, 2004).

30 The upper parts were light yellow, and the lower parts were green. They carried up to 12-14 people (Makarac1 cited in Ergir, 2004).

31 In the cadastral map that was produced between 1925 and 1932, the square was labelled as Zafer Square, whereas most of the official documents and photos use the name Millet Square. Şenol Cantek stated that after the erection of the Victory Monument in the square, residents began to call that district Heykel [Monument] (2003, p.288). Although different names were used both by officials and the public, in this study the name Millet Square will be used. 
Between 1924 and 1929, Millet Square was transformed into one of the most important urban spaces of Ankara. As well as being located at the junction of main roads, such as Büyük Millet Meclisi/ İstasyon, Çankırı, Mekteb-i Sanayi and Karaoğlan, it was the introductory space of the city for visitors arriving by train, and was the closest commercial district to the train station. Furthermore, its significance was also due to being at the centre of the commercial activities of the city, most of which were concentrated around the main roads and secondary streets located in the area that began with Millet Square, Karaoğlan, Balıkpazarı, Tahtakale and Suluhan (Tunçer, 2001 , p. 89). On the other hand, administrative centre was located in the area between Büyük Millet Meclisi Road and Hükümet Square since most of the governmental buildings, such as the National Assembly and ministries, were in this location.

Concurrently, a new financial centre was emerging in the surrounding area. Several banks opened one after another in quick succession, transforming the character of Mekteb-i Sanayi Road and turning it into the financial axis of the city. The transformation process started with the construction of Osmanlı Bankası [Ottoman Bank] to the south of the road, continued with the construction of Ziraat Bankası [Agricultural Bank] to the north, with the process being finalised by the construction of Iss Bankası [Business Bank] in the western part of Millet Square. Since this axis connected the major financial spots of the city, its name soon changed to Bankalar Caddesi [Road of Banks (Bankalar Road)] during the first decade of the Republic.

Millet Square also became a centre for entertainment and leisure time activities. Kulüp Sineması [Club Cinema (Kulüp Cinema)] was located at the junction of Çankırı Road and 30 Ağustos 1922 Road (today's Rüzgarlı Street), while Yeni Sinema [New Cinema (Yeni Cinema)] (Figure 21A), İstanbul Pastanesi [İstanbul Patisserie] (Figure 21B)

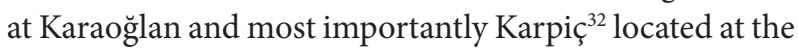
entrance floor of Taşhan (Figure 21C), were important entertainment centres in Millet Square. Karpiç, in particular, became one of the most famous places in the city that allowed, for the first time in the history of Ankara, women and men to eat good food and listen to music together in a restaurant (Bağlum, 1992, p. 144).

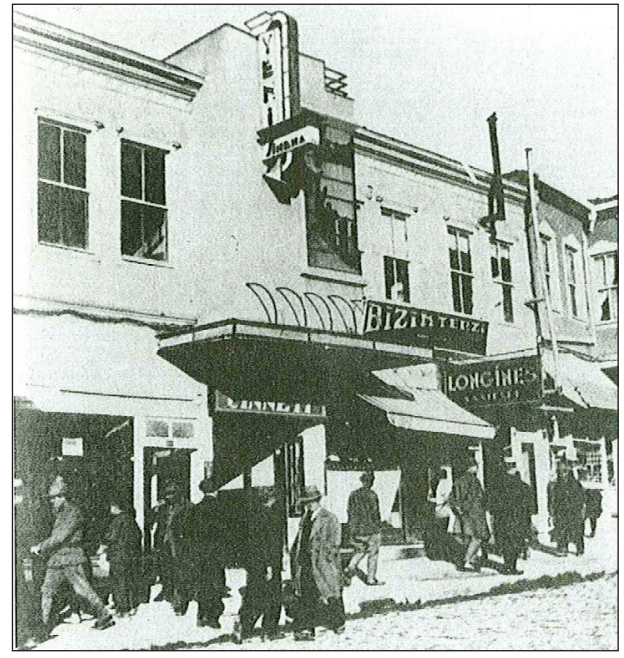

Figure 21A. Entrance of Yeni Cinema, 1930's. Source: Ankara Posta Kartları ve Belge Fotoğrafları Arşivi, 1994, p. 101.

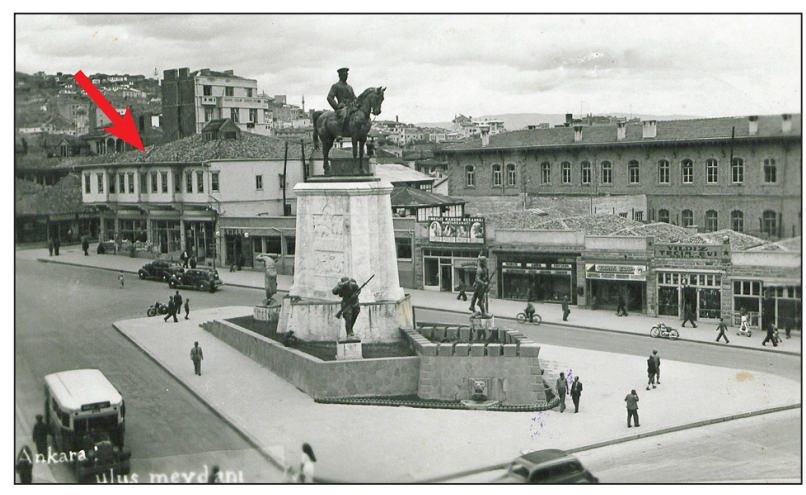

Figure 21B. İstanbul Patisserie.

Source: VEKAM Library and Archive, Inventory no. 1486.

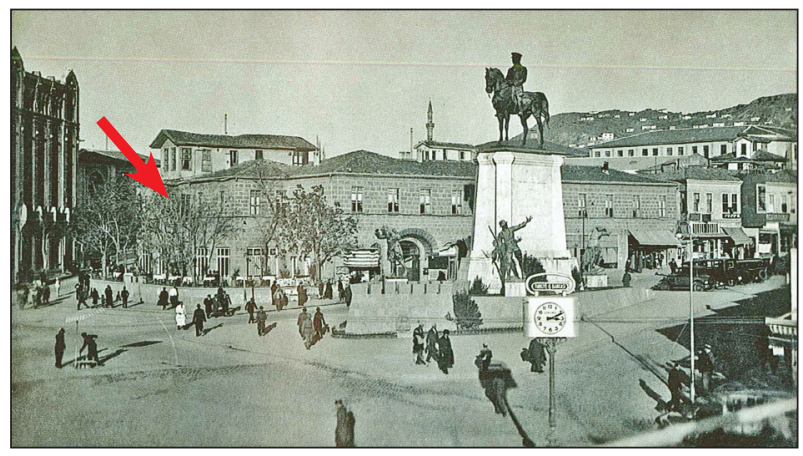

Figure 21C. Karpiç, at the entrance floor of Taşhan. Source: Cangir, 2007, p. 1081.

32 Even though Şölen Lokantası [Feast Restaurant] was the restaurant's official name, Karpiç Lokantası was commonly used by the public. The name Karpiç is therefore used to refer this restaurant. For detailed information see İlkin (1994, p.66). 
As well as the previously mentioned places, there were also several pavyons, ${ }^{33}$ bars and gazinos that were mainly concentrated at the southern parts of Çankırı Road where it meets Millet Square. ${ }^{34}$ The oldest and most popular ones were Elhamra Bar and Tabarin Bar, the customers of which were among the notable male figures of the period. ${ }^{35}$ A prestigious club called Ankara Kulüb $\ddot{u}^{36}$ also continued to function until 1927 on the upper floor of Düyun-u Umumiye on the Bankalar Road. In addition, Ankara Palas, located on Büyük Millet Meclisi Road ${ }^{37}$, was popular both day and night for "housing of balls and parties as stages for the new lifestyle that was being spread nation-wide" (Batuman, 2008, p. 99). The balls, meetings and celebrations that were organised at Ankara Palas were attended by many notable figures, politicians and bureaucrats of the city. ${ }^{38}$ The Ankara Palas was also used as the state guesthouse, and important guests (ambassadors, kings, diplomats etc.) were lodged there. As a result, as it was the centre, Millet Square became the landmark of Ankara due to its connecting of commercial, administrative, financial and also many socio-cultural activities.

A rapid rise in the population, due to people moving to the capital city from all over the state, created the need for additional residential areas. This led to an inevitable expansion of the city outside of the historic quarters, to the north and the south. This expansion resulted in the emergence of a new city centre in the south, which had in fact been proposed by Lörcher that became known as Yenişehir [New City]. In the following years, the municipality held an invitational competition and Herman Jansen's proposal was chosen in 1929 as the winner. However, due to the fact that preparation of Jansen's original master plan would take three years, and between the years of 1929 and 1932 development in Ankara could not be restrained. Most of the urban construction and planning activities were based on an incomplete proposal, which would lead to eventual serious problems and irreversible harm being caused to the city.

With the construction of additional buildings such as Meydan Palas, Koç Han and Kulüp Cinema, Millet Square started to gain a more definite form (Figure 23B). Furthermore, development of an Ottoman Millet Square into a modern Republican Millet Square occurred with the erection of Merkez Bankası [Central Bank] in 1931 on Bankalar Road (Figure 22). Central Bank, the location of which is labelled on Figure 23B, was constructed to the south of Millet Garden, and clearly marked the southern edge of Millet Square.

Moreover, an additional bazaar, named Muhasebe- $i$ Hususiye (Özel İdare) Çarşısı, was constructed at Millet

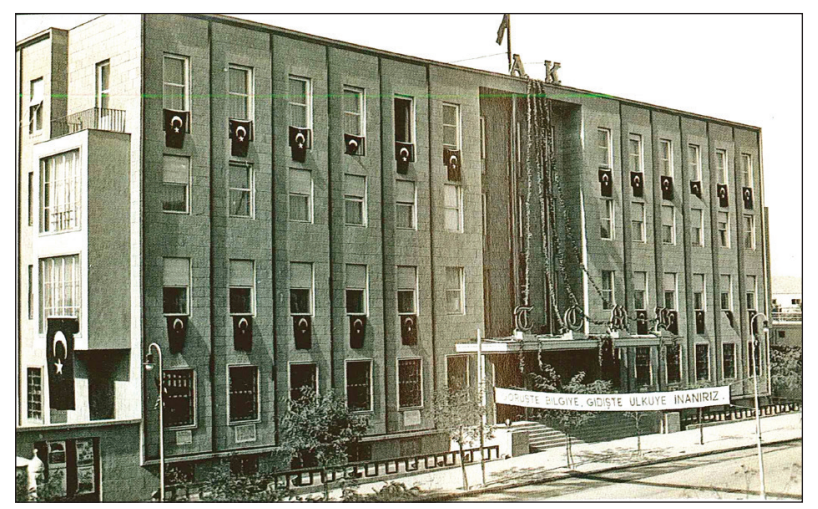

Figure 22. Merkez Bankası, 1933.

Source: Cangir, 2007, p. 1242.

33 Pavyon, originating from the French word 'pavilion', is a night-time place of entertainment where alcoholic beverages are available.

34 Starting from the mid-1920s, Çankırı Road became the main location for most of the bars, pavyons and nightclubs of Ankara. It is possible that, during his visit to Ankara in 1921, Streit's description of a "small limited area reserved for gambling and inebriety" (2011, p.63) could refer to the southern parts of Çankırı Road.

35 A mini orchestra composed of 3-4 players played onstage at these bars between $10 \mathrm{pm}$ to $3 \mathrm{am}$. There were usually street peddlers waiting around the entrance of these bars to sell food to the customers. Due to these activities, the usage intensity of Millet Square increased.

36 Lady Drummond Hay, an English woman who visited Ankara in 1926, recorded her experiences in an article published in The Daily Express, London on 25.05.1926. In the article, she stated that one could comprehend the real spirit of New Turkey in Ankara Kulübü (cited in Şimşir, 2006, p. 371).

37 This part of İstasyon Road (between Baruthane Square and Ulus Square) was renamed Büyük Millet Meclisi Caddesi [National Assembly Road] after the opening of the assembly.

38 In his novel 'Ankara', Karaosmanoğlu depicted the atmosphere of balls and activities organized at Ankara Palas by focusing on the socio-cultural profile and daily lives of the attendees (2001, p. 109). 
Garden. This bazaar was composed of small-attached shops facing Bankalar Road, and shortly afterwards a similar type of attached commercial buildings were erected right across Bankalar Road (Figure 23A and 23B), meaning that famous brands started to appear at this location..$^{39}$ Among these brands, the transfer of Karpiç to the place, which had been previously occupied by Fresco Bar had a special meaning for Millet Square since it accelerated the decline of Taşhan. This event was a catalyst for a series of changes to take place in Millet Square as, after the extension of commercial units from Karaoğlan to Bankalar Road, this axis started to become an important commercial spot for the city with shops on both sides of the road.

Another important event, which affected Millet Square was the attempt by the state to "purify" Turkish of other languages by suggesting alternatives to words and expressions that were in common use, but were of non-Turkish origin. Hence, there has been a major breakthrough in the Turkish Language Revolution after the establishment of Türk Dil Kurumu [the Turkish Language Institution] on 12 July 1932. As part of the language reform, as the case with several other revolutionary regulations of the state, the official name of Millet Square was changed. Since the word "Millet" is Arabic, the name was replaced with a new word that was believed to be "pure Turkish". Therefore, in 1932, the alternative name that was chosen to replace Millet was Ulus, and it was required that this name be henceforth used in official documents. ${ }^{40}$

In the same period, Jansen's development master plan was approved in 1932, and this marked a period of construction in the city, which continued until the beginning of 1939. Jansen's plan emphasised and directed the development of Ankara to the south in the direction of Yenişehir (today's Sihhıye and Kızılay ${ }^{41}$ ),

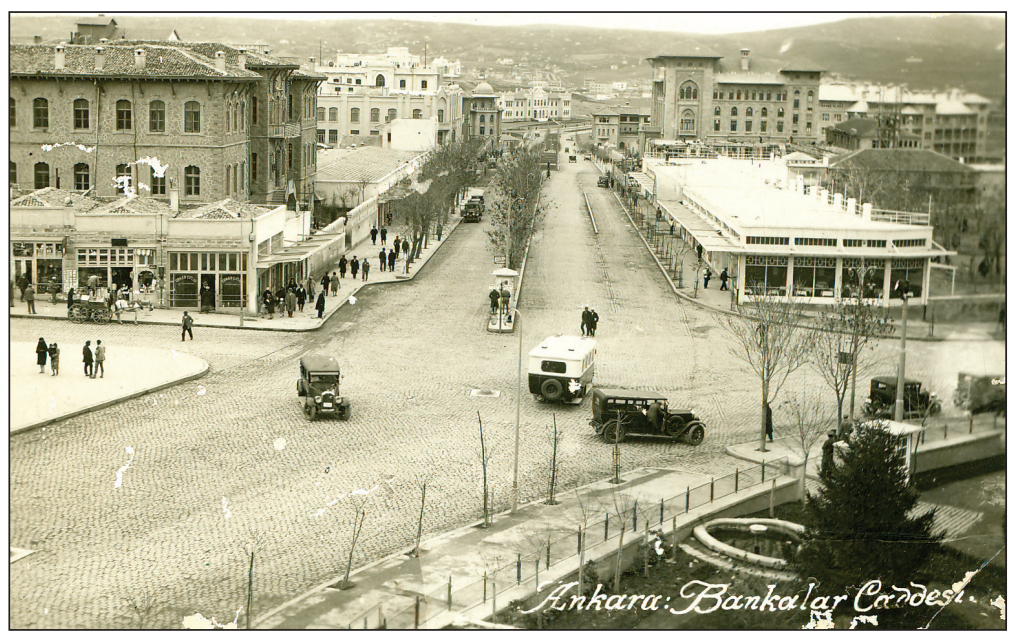

Figure 23A. Bankalar Road: Both sides lined with small shops, 1930. Source: VEKAM Library and Archive, Inventory no. 1316.

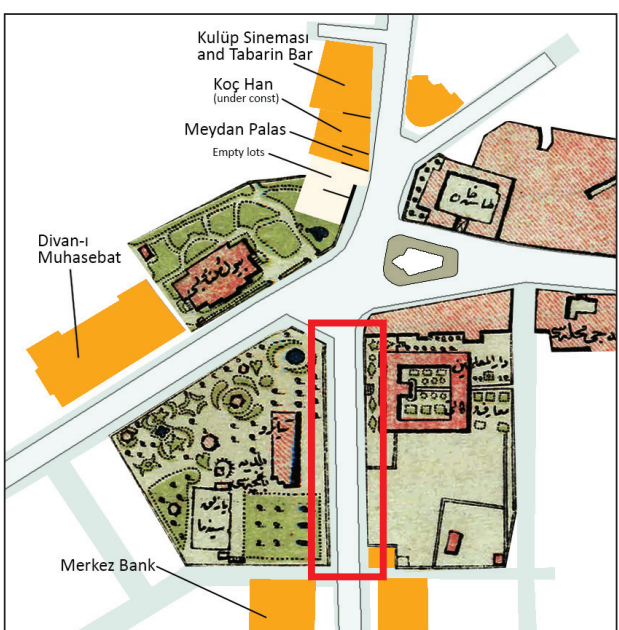

Figure 23B. Schematic view of Millet Square, 1931: Muhasebe-i Hususiye (Özel İdare) Çarşısı indicated with a red rectangle.

Source: Edifices constructed after 1924 are labelled by the author on Ankara City Map, VEKAM Library and Archive, Inventory no. H004.

39 On one side, next to the Ministry of Education, a market, a grocery, Kavaklıdere Wine Factory's shop, the Vagonli ticket office, tailors (Necati Halit and Yaşar Kotay), a barber and the bookshop of the Ministry of Education were opened. On the other side of the road, in front of Şehir Bahçesi [City Garden] (Millet Garden's new name), brands like Hacı Bekir (confectionery), Osman Nuri Bey (confectionery), Akba Kitabevi (bookstore), Hachette (bookstore), Gömlekçi Orhan (shirt maker), Sabuncakis (the famous İstanbul florist), David (garments), Photo Naim Gören etc. were either opened their first shops in Ankara at this location, or moved their existing shops from the old districts to this new commercial area.

40 In parallel with these changes, the name of the official newspaper of the state was changed from Hakimiyet-i Milliye Gazetesi to Ulus Gazetesi on 28 November 1934 (Önder, 2013).

41 At the end of the 1930s, Kizılay Square became one of the most important squares of Ankara with its theatres, buildings, monuments and fountains (Cengizkan, 2004, pp.75-76). 
Bakanlıklar ${ }^{42}$ and Çankaya. In addition, one of his ideas from his previous proposal to connect Bankalar Road, Yenişehir and Çankaya was implemented in 1929 as a $30 \mathrm{~m}$ wide road (a boulevard), which began to be utilised as a protocol road. Even though, in its early years, this road cannot be considered as being equal to a European boulevard or avenue in terms of its vitality and use (Karaosmanoğlu, 2001, p. 176), it did become the most important axis of the city, and was particularly useful for municipal activities (Figure 24A and 24B). Until 1934, this road was referred as Gazi Boulevard, later becoming Atatürk Boulevard at the end of the 1930s.

At the beginning of March 1935, Taşhan was surrounded by construction safety panels, signifying that the demolition process had started (Sarığlu, 1995, p. 192). With its removal, Ankara lost a building that had both historic, functional and memory value for the entire city and most of its residents. In fact, it was later realised that this event was a precursor to several more changes. ${ }^{43}$ The change in the physical character of historic parts of Ankara, and especially in Ulus Square, would have an impact on the function and profile of the square in the immediate future. Simultaneously, the number of new buildings constructed and roads planted with trees (mainly acacia) in the newly developed districts (especially Bankalar Road) were increasing day by day. By directing the development activities to the west and south, and by creating a new residential and administrative area at Yenişehir, a new city centre had started to emerge around Kizllay. Moreover, starting with the influx of commercial activities from Karaoğlan to Bankalar Road, a major functional distribution was occurring within the city as shops and businesses began to relocate themselves slowly from Ulus Square to the direction of Yenişehir. However, by neglecting old districts or, in many cases, not taking sufficient measures to determine the future of empty lots, authorities underestimated the risk of the expansion of squatter areas (Figure 25A and 25B). ${ }^{44}$

\section{Acceleration of Modernisation Activities}

During late 1930s, modernisation activities continued more intensely in Ulus Square as compared to other parts of the city. Even though most executive institutions had moved to the Bakanlıklar district in Yenişehir by the end of 1930s, the legislative body remained in the main public square of the city (Batuman, 2017, p. 49). Therefore, Ulus

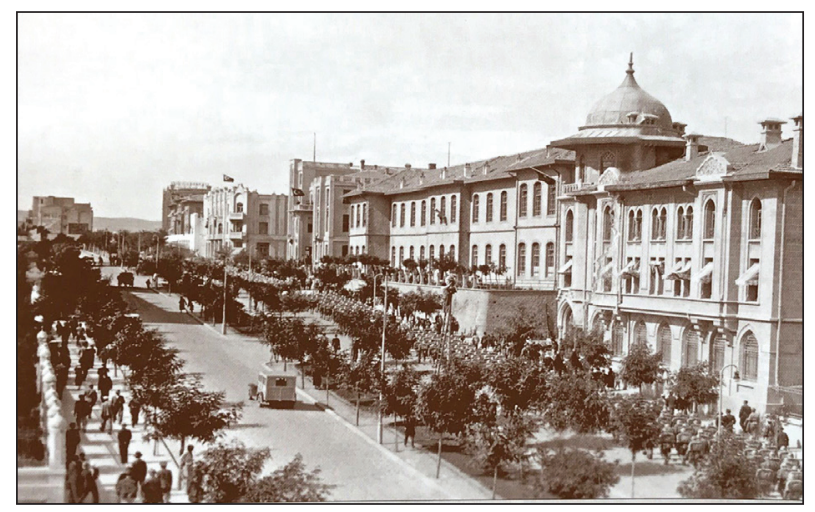

Figure 24B. Bankalar Road, subsequent years with a greener appearance, 1934-1935.

Source: Tekcan, 2014, p. 100.

42 Between 1927 and 1935, a large number of ministry buildings were constructed in the Bakanliklar [Ministries] district such as Interior (19321934), Labour (1929-1934), Public Works (1933-1934), Commerce (1934-1935), Defence (1927-1931) etc. This meant that administrative functions were distributed around Ulus and Kizilay.

43 In 1934, Belkız Sütunu/Julian Column, which was erected at the west-southwest of Hükümet Square in 361-363 AD, was relocated at the east of Hükümet Square. This opened an additional space for the new building that would be constructed in place of Taşhan.

44 In 1934, Şükrü Kaya (Minister of Interior between 1927 and 1938) pointed out in his speech that the third Ankara consists of houses that were constructed within one or two nights. Even though there were several activities to demolish the houses which were located on squatter areas around İncesu and Akköprü districts, the state still had much do to revitalize squatter areas in Ankara (Ergüven, 1938, p. 130). 

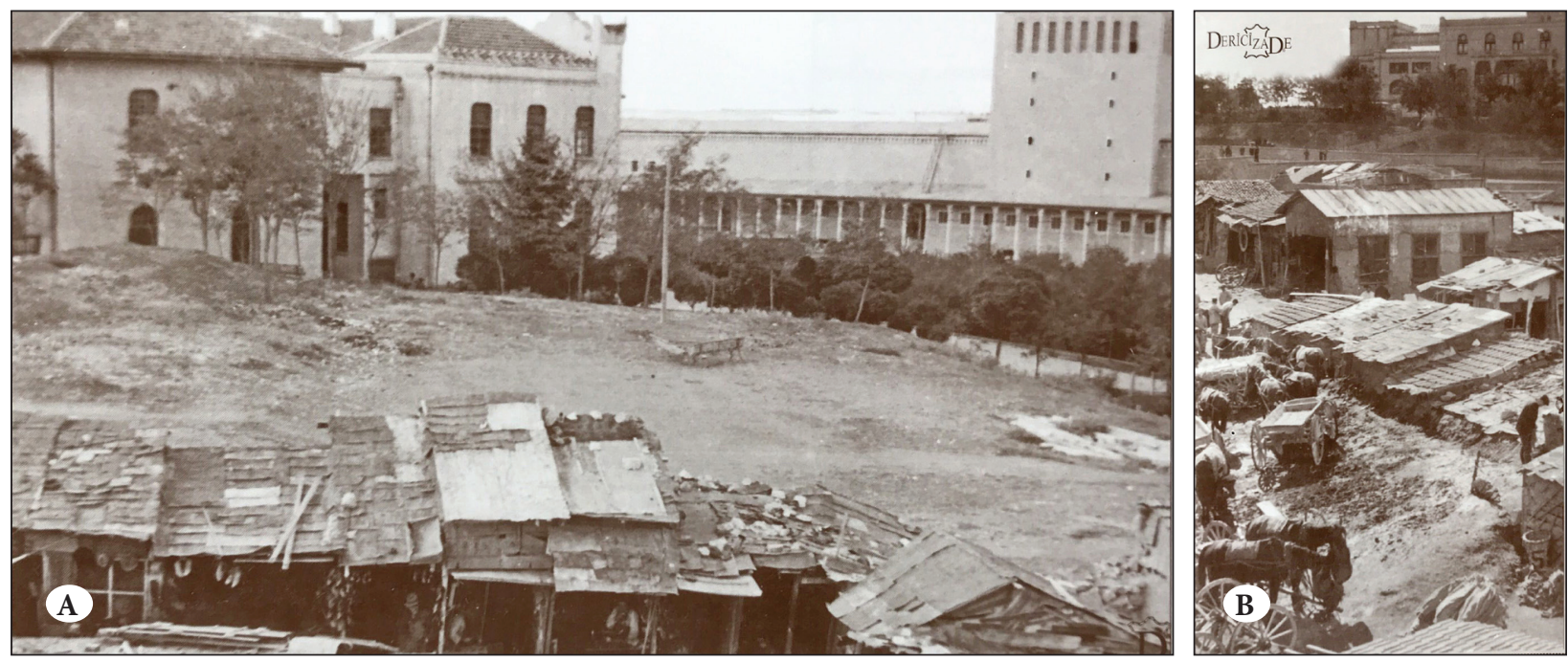

Figure 25A and 25B. Barracks erected at empty open spaces around the Ministry of Foreign Affairs.

Source: Tekcan, 2014, p. 174.

Square retained its importance for the city by hosting the National Assembly, the Governor's Office and the Victory Monument in its close vicinity. As Ulus Square contained obvious national symbols, such as the government, administrative buildings and the monument symbolising the days of the War of Independence and victory, main roads of this square were a natural choice for public activities, gatherings and state celebrations. ${ }^{45}$ In addition to its administrative functions, Ulus Square continued to strengthen its ideological meaning for the city. The monument and its surrounding areas were, in particular, considered almost sacred by visitors of the district.

As well as becoming known as symbol of nationalist pride, the public buildings, wide planted roads, green open spaces, theatres-cinemas-gazinos-restaurants, and most importantly, due to the people living in complete harmony with the Republican ideology regarding their clothes and daily activities, Ulus Square was gaining a more modern appearance. Clear evidence of this trend can be seen from the depictions of foreign journalists who visited Ankara in this period. For instance, in the article "Ankara, The Heart of New Turkey", M. Svetovski (1936) ${ }^{46}$ states that: With its geometrical lined boulevards, the new and mosque-free Ankara stands as the bravest example of aesthetics and secularity... Ankara commands attention by being a symbol of determination and human victory.

Henri Liebrecht ${ }^{47}$ was also impressed by Ankara and wrote the following in 1937:

And there it is, Ankara... What was previously only a small Turkish village and an almost demolished castle, these arid lands have become the new administrative centre of the new Turkey in just 12 years... A few minutes ago, we were in the middle of a desert; but after we embarked from the station, we found ourselves in the middle of the dynamism and vitality of a modernised large city, with asphalt-paved roads in stark contrast to the narrow, crooked streets of İstanbul... (cited in Şimşir, 2006, pp. 405-406)

45 Until the opening of the Stadium and the Hippodrome in 1936, Ulus Square and these roads continued to be used for state celebrations. After the construction of new spaces, most of the ceremonial activities had moved to the Stadium and to the Hippodrome. Even though this change had meant that Ulus Square and its close vicinity were less frequently utilised by the state as an official ceremonial space, these areas continued to be used for public meetings and celebrations by the residents of Ankara.

46 Vreme/ Belgrad.

47 Le Soir/ Brussels. 
The other important development for Ankara was the construction of a new Central Train Station with an adjacent restaurant and gazino in 1937, at the same location of the previous train station (Figure 26A). By introducing neat solutions to the spatial and structural problems of contemporary architecture (Yavuz, 1994, p. 208), this new train station created a compatible image with the modernised face of the city. As the new restaurant by the train station met western standards and was one of the most luxurious in the city, the station area soon became the main gathering place for notable figures and high-income groups (Uludağ, 2005, p. 32). This meant that İstasyon Road was gradually transformed into one of the most important and crowded roads of the city, with Gar Gazinosu [Station Gazino] on one end and Ankara Palas on the other (Figure 26B). By linking the gate of the city to the main central public open space, İstasyon Road allowed the state to strengthen the idea of a modernised Ankara. Therefore, it was not long before, in addition to Atatürk Boulevard and Büyük Millet Meclisi Road, the station area and İstasyon Road also became part of the modern physical, visual and socio-cultural face of Ankara.

In parallel to the erection of new buildings around the train station, other monumental buildings and public spaces were also being designed and constructed within Ulus Square and its close vicinity to reflect the modern face of the Republic. A considerable number of parks, sport and recreational facility areas were built in Ankara during 1930s that also became urban and architectural

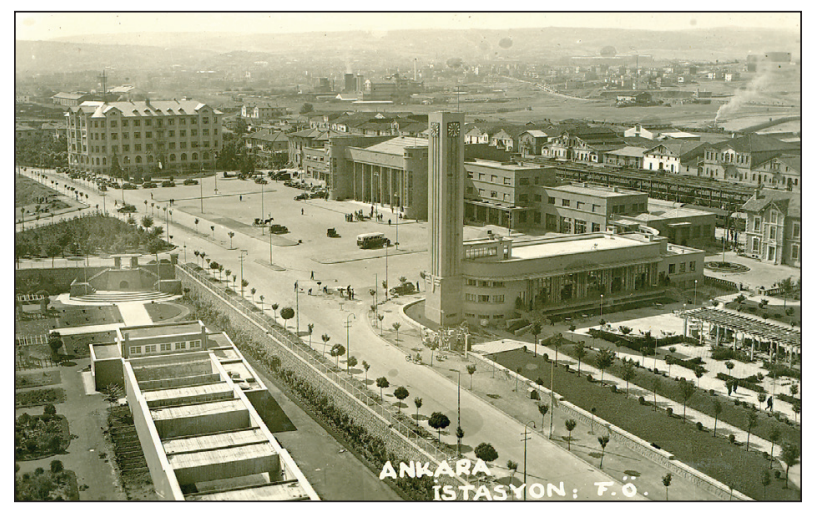

Figure 26A. Station Square, General Directorate of State Railways, The Central Train Station and Gar Gazinosu, 1939. Source: VEKAM Library and Archive Inventory no. 0758. icons of the Republican modernity (Bozdoğan, 2001, p. 75). For instance, 19 Mayıs Stadyumu [19 May Stadium] was a sports complex that was also used as a venue for many celebrations during national holidays. Therefore, after the opening of this complex in 1936, ceremonial activities were gradually moved from Ulus Square to the Stadium area, and this had an inevitable negative effect on the ceremonial usage of the square. On the other hand, Ulus Square and Atatürk Boulevard continued to be utilised for parades and ceremonies during national fests and special events.

Among several other new constructions within the area, Sümerbank [Sumerian Bank] occupied an important place for the square as it accelerated the physical, functional, and visual transformation of Ulus Square and its meaning for the city. As Scott suggests, the fascination with productivity is a defining feature of the high modernist vision (1998, p. 99). Therefore, as with other countries of the period, Turkey also focused on industrialisation as a major element of the modernisation process of the Republic. Among the state's industrial initiatives, the construction of industrial buildings all around the country became pillars of the promotion of modernisation progress of the state. It was also part of the national will to construct a modern nation by implementing modern architecture as the setting of the daily life. Ankara was no exception to this, and the building of Sümerbank in 1937-1938 was a perfect example of the construction of a monumental building that symbolized the industrialisation of the Republic. Sümerbank was erected at the most important

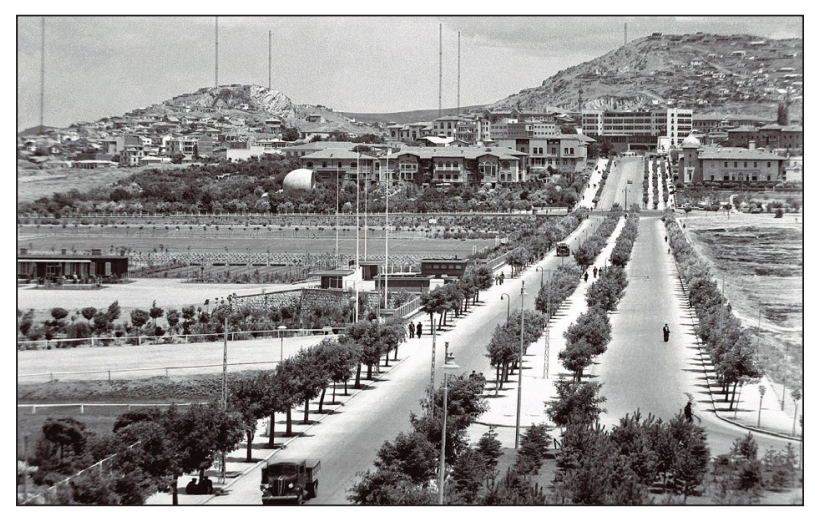

Figure 26B. İstasyon Road, 1930s.

Source: Levent Civelekoğlu Archive. 
location of the city centre where Taşhan had previously stood (Figure 27A and 27B). After the construction of Sümerbank, a new era began for Ulus Square. Both with its name, meaning, architectural features, and most importantly, the way it changed the visual and functional aspects of Ulus Square, Sümerbank became a landmark for both Ankara and the whole of Turkey.

\section{Tandoğan as the Main Actor in Urban Development}

During the 1930s, land speculations, economic factors and the personal interests of notable figures of Ankara gradually increased their pressure on Imar Müdürlüğ̈ [Directorate of Development] and interrupted the efforts made by the authorities to fully implement Jansen's plan. During the frequent occurrence of conflicts between the plan and the personal interests of landowners, there were disputes over minor changes. In fact, attempts to change the plan began as soon as it commenced (Bademli, 1994, p. 162). Especially the conflicts between Jansen and Tandoğan (the mayor-governor of Ankara) that began in 1935, as well as increases in several other interruptions of administrative bodies in the implementation of the plan eventually resulted in Jansen's resignation in 1938.

On the following years, the Second World War (19391945) created new agendas for Turkey. Despite the fact that the country decided to remain neutral during the war, Turkey was not immune to the effects of political shifts and economic fluctuations. As it was the capital of the Republic, Ankara was particularly exposed to the economic-political consequences of war in terms of the effects on urban space. While Ulus Square continued to

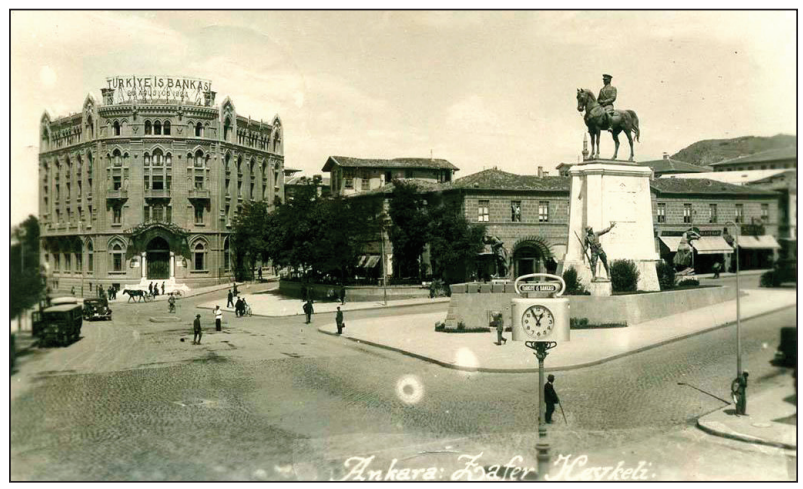

Figure 27A. İş Bank, Taşhan and the Victory Monument, 1931. Source: VEKAM Library and Archive, Inventory no. 1207. maintain its importance for the city during this period as the main administrative, commercial, financial and leisure centre of Ankara, it was possible to observe the impact of political and economic conflicts within the state on the physical, functional and socio-cultural character of the square.

Between 1938 and the end of 1940s, Ankara Municipality implemented several partial urban development projects. After Jansen's resignation, and with the full administrative power of Mayor-Governor Tandoğan in urban activities, the period between 1939 and 1945 can be considered as being Tandoğan's period as he was influential in almost every decision regarding the city (İmga, 2006, pp. 125127). Tandoğan's limitless authorisation accelerated the development process of the partial implementation projects that were shaping the newly developed modern parts of the city.

During the early periods of Tandoğan, Atatürk Boulevard was the main artery of Ankara, which connected Ulus Square to Yenişehir. It was a $30 \mathrm{~m}$ wide road with trees planted on both sides of the broad sidewalks, as well as on the median refuge (Batuman, 2017, p. 67) (Figure 28A). Yenişehir district, which had started to emerge on the southern end of Atatürk Boulevard, continued to develop as the one and only residential centre of Ankara with its modern streets suitable for motor vehicle traffic, one-two storey houses and private gardens. Therefore, Yenişehir soon became an entirely disparate environment, in terms of its physical aspects and the daily life of the residents (Figure 28B). As the densely inhabited quarters of traditional Ankara suffered from various problems, Yenişehir became the most popular area for residents

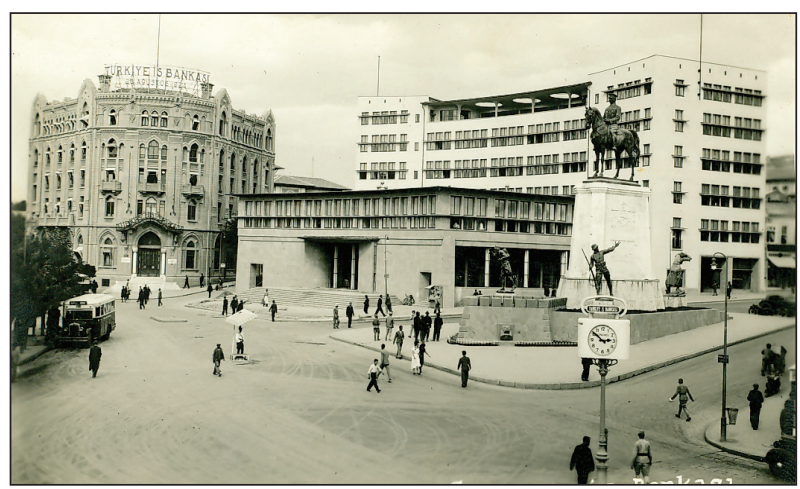

Figure 27B. İş Bank, Sümerbank and the Victory Monument, 1940. Source: VEKAM Library and Archive, Inventory no. 0846. 
who could afford the trappings of a modern life style. In 1939, Ertuğrul Şevket Avaroğlu described his visit to Yenişehir as follows:

As soon as we crossed the railway bridge into Yenişehir, the scenery changed completely. I encountered a gallery with green paintings. The pine and locust trees planted on both sides of the straight road were swaying in the spring breeze. A fine stream of water pleasantly poured out of the cherubs and into the pool between tree branches (cited in Tanyer, 2009, p. 150).

The northern part of Atatürk Boulevard, previously known as Bankalar Road, was still considered as the most prestigious part of Ankara specifically with the erection of one bank after another. Moreover, high-quality shops

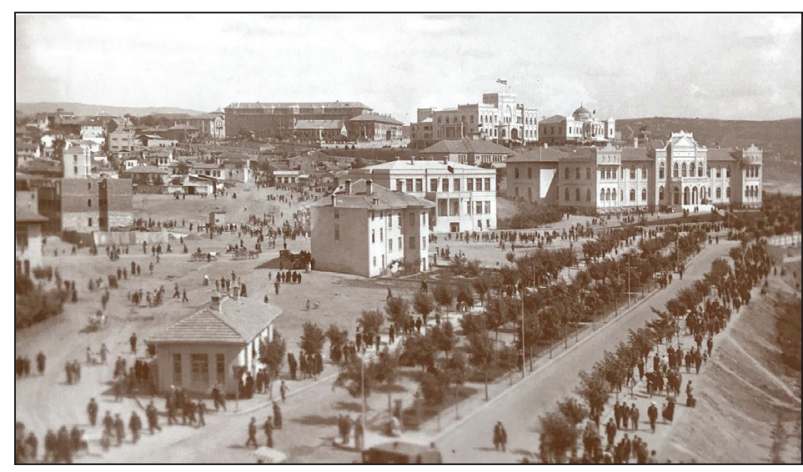

Figure 28A. During the early 1940s, walking along Atatürk Boulevard became a daily ritual for Ankara residents. Source: Tekcan, 2014 , p. 86. with products mainly imported from Europe were located at the intersection where Bankalar Road met Ulus Square. In addition to Bankalar Road, also Karaoğlan and Anafartalar Road were defined as being the favourite shopping areas of Ankara during the early 1940s (Figure 29A, 29B and 29C). Moreover, Ulus district was the main area where different kind of restaurants, cafes, patisseries and bars were concentrated. Starting from Karpiç to the direction of either Çankırı Road (north), or sprawled around Karaoğlan-Anafartalar axis (east-north east), gastronomic activities also increased the usage of this area at night.

Economic problems of the early 1940s also affected the municipality in terms of budgetary savings, and the bus fleet was unable to meet the demands of Ankara's rapidly

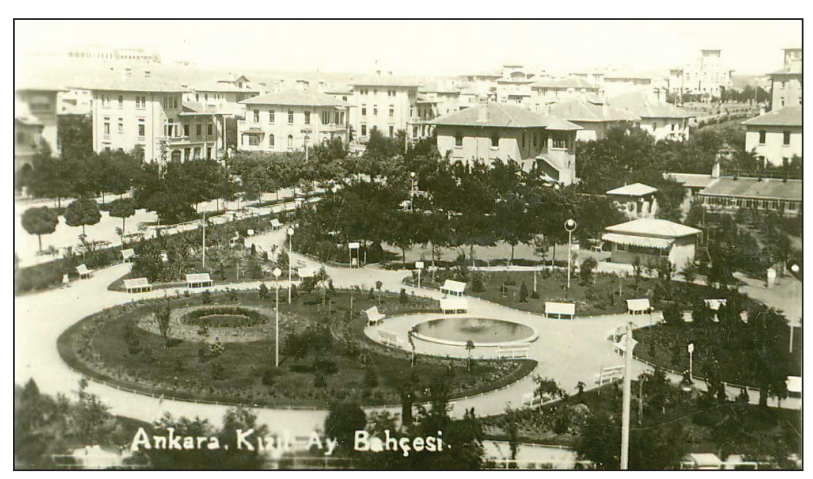

Figure 28B. Kizilay Square: densely planted with trees. Source: VEKAM Library and Archive, Inventory no. 1392.
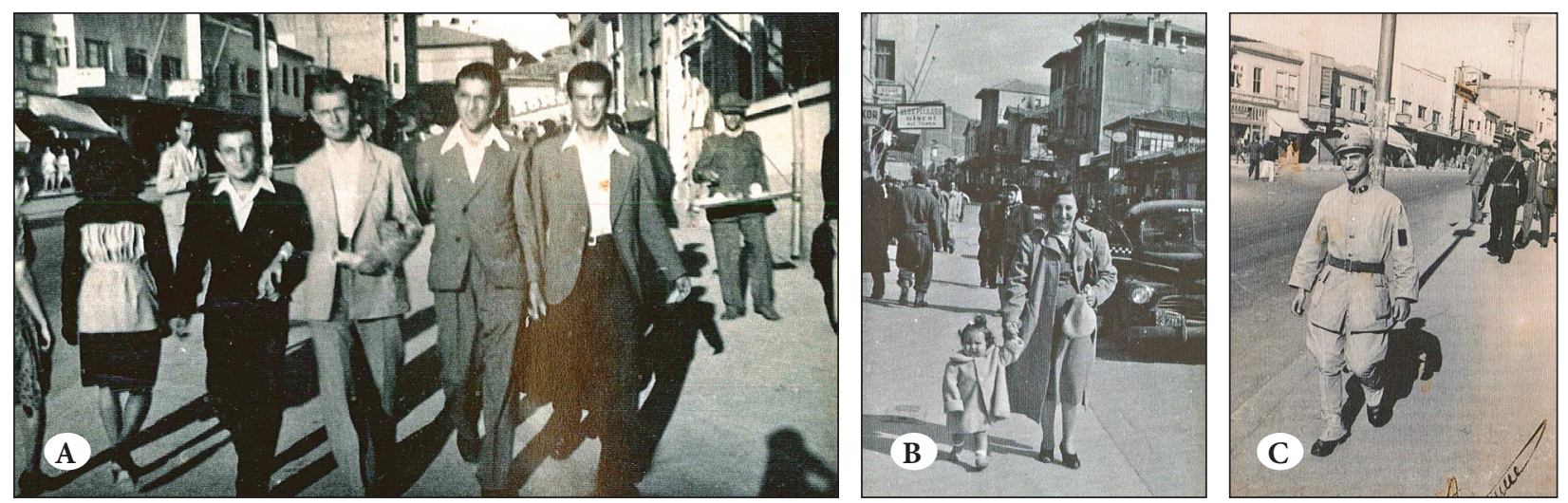

Figure 29. From the 1940s onwards, having your photo taken while walking at the streets of Ankara, especially in Ulus Square and its close vicinity, became popular A. Karaoğlan (Source: Cangır, 2007, p. 1096). B. Anafartalar Road (Source: Cangır, 2007, p. 1097). C. Karaoğlan (Source: Cangır, 2007, p. 1099). 
increasing population. ${ }^{48}$ To handle the problems caused by an insufficient number of public buses, a new form of public transportation emerged. Introduced by private entrepreneurs as a shared-taxi (which would later be called a taxi-dolmuş), this mode of transportation was the first solution to meet the demands of public transportation (Tekeli and Okyay, 1981, p. 67). The transformation of Ulus Square from the central urban square of Ankara into a transportation hub had its roots in the increasing role of public transportation, which began around this period.

\section{Post-War Conditions and the Emergence of a New Understanding of Urban Space}

The years following the end of the Second World War witnessed the emergence of global new orders and associations. The political, administrative and financial structure of many countries was breaking down, while new forms of understanding of political unifications emerged to replace the older ways. Parallel to these radical changes, Turkey also witnessed a shift, both in its interior and exterior structural organisation and in its relationships. As an outcome of this shift, and also due to the effect of the new political system in Turkey, the early 1950s witnessed radical changes in the administrative structure, as well as in legal issues of urban development and its implementation.

In the wake of the Second World War, the years of 19451946 were particularly significant in terms of prefiguring the end of an era in which single party domination was questioned and alternative ways were discussed. In addition to Turkey's internal struggles, international relations were also unstable. Starting with the economic aid agreement between USA and Turkey, day to day interests of USA had a profound effect on the external and internal policies of Turkey. By the end of the 1940s, it was possible to observe American impact on the country, not only in economic activities, but also in governmental policies regarding socio-cultural and urban development issues. Among several other areas, the American impact on the socio-cultural and ideological structure of Turkey, including the distribution of the population within the country, daily life and routines, and most importantly, urban development policies, can be followed in this period.

First, with relation to the mechanisation of agriculture in the country, ${ }^{49}$ American influence caused an erosion in the labour oriented structure, and the period saw the creation of a new unemployed community composed of villages and peasants. While mechanisation of agriculture was mainly supported by the Marshall Plan, it also resulted in a serious increase in the number of immigrants, mostly villagers and peasants, in big cities during $1950 \mathrm{~s}^{50}$ However, the newly developing, but limited, industrial and service sectors in urban areas were not able to absorb this influx of rural immigrants (Duyar-Kienast, 2005, p. 35). As a result, the squatter areas of Ankara, which emerged in the late 1920s-1930s in the open spaces close to Ulus district, started to expand into the outskirts of the city and eventually surrounded historic Ankara. Even though several legislative regulations were issued ${ }^{51}$ to deal with this problem, squatter areas, illegal construction activities, attempts to increase the height of buildings and land speculations increased more than any period of the Republic. $^{52}$

The second important event, which increased the growing dependency of Turkey on the USA was due to the overwhelming influence of American culture that was mainly manifest through intense presence on radio programmes, as well as in magazines, posters, advertisements and movies. It was not long before American culture had become the ideal in the popular culture of Turkey (Alkan, 2015, p. 595). In her novel, Ayşe Kulin depicts how the social life of Ankara was being profoundly affected by American culture:

48 Ankara was the only city in Turkey which had around six percent population growth. On the other hand, when compared to previous years, the population growth of cities such as İstanbul and İzmir was decreasing (Tekeli, 1978, p. 48).

49 The Country Report on Turkey, submitted to Congress by the State Department on 15 January 1948, pointed out that as Turkey's economy and exports were overwhelmingly based on agriculture, this would require the recovery program to concentrate upon the development of the agricultural, rather than the industrial sector (Üstün, 1997, p.35). Therefore, most of the money given by the USA to Turkey as part of the Marshal Plan aid was spent on the agricultural sector.

50 The population of Ankara increased by $89 \%$ between 1935 and 1950 .

515218 issued in 1948: Ankara Belediyesine, Arsa ve Arazisinden Belli Bir Kısmın Mesken Yapacaklara 2490 Sayılı Kanun Hükümlerine Bağlı Olmaksızın ve Muayyen Şartlarla Tahsis ve Temlik Yetkisi Verilmesi Hakkında Kanun [Law on the Allocation of Municipality and Government Lands for the Construction of Houses in Ankara].

52 The number of floors of the buildings located on Atatürk Boulevard increased to four between 1940 and 1950 (\$̧enyapilı, 1985, p.103). 
Meltem started to date with an American private (soldier) who was commissioned in Ankara. During those days, it was really popular to make friends with Americans or to wear American clothes. Most of the young girls were hoping to find an American boyfriend. Wearing American shoes, socks and sweaters immediately gave the feeling of superiority over others (cited in Bozyiğit, 2002, p. 221).

As outlined above, the dynamics of the world were completely changing, and Turkey was likewise experiencing profound changes in economic, political and socio-cultural policies. In the election of May 1950, the DP (Demokrat Parti, [the Democratic Party]) swept to power and their victory would significantly transform the nature of Turkish politics. By increasing the role of private enterprise on financial issues, exposing the Turkish economy directly to the American market, and supporting the integration of the American and Turkish culture, DP policies also triggered the emergence of a new understanding of architectural and urban space production.

The construction of the "modern" city understanding was based on the model of the American Metropolis, where the architecture, now serving the needs of the liberal economy, had adopted the architectonic forms of this inter-national system of capitalism (Yalım, 2001, p. 157). By this way, with the governance of DP a new urbanisation period began. From then on, the Republican way of utilizing architecture and urban space had been replaced by new strategies of DP in urbanisation, which mainly shaped and managed by the market demand and the popular architectural tendencies converted from USA. Moreover, Celal Bayar, the president during the period that the DP was in power, explicitly stated his party's Americanisation strategy by envisioning a Turkey that would be like a mini-America in 30 years' time (Celal Bayar, 30 yll sonra Türkiye, 1957, 21 Ekim, p. 1). Furthermore, it could be said that the architects of the period were under the influence of international forms that were popular as the country became more oriented towards the United States (Sözen, 1984, pp. 273-285). In fact, most of the architectural works produced in this period had clear references to buildings designed in the USA.

Concurrently, between 1952 and 1953, an architectural project competition was held for buildings to occupy the empty land where previously Darülmuallimin had been located, but had burnt down in 1947. This project became one of the most important determinants in the transformation of Ulus Square and its close vicinity. The winner of the competition was the project designed by Orhan Bolak, Orhan Bozkurt and Gazanfer Beken. Their winning design, Ulus İşhanı ve Çarşısı [Ulus Office Block and Bazaar] project was designed with similar intentions of international style of its period, with both sides of their tall office block design consisting of rectangular prisms of different heights and convex facades (Aslanoğlu, 1994, pp. 237-238) (Figure 30). The construction of the building started in 1955, and subsequently triggered a series of other physical changes in Ulus Square during the 1960s.

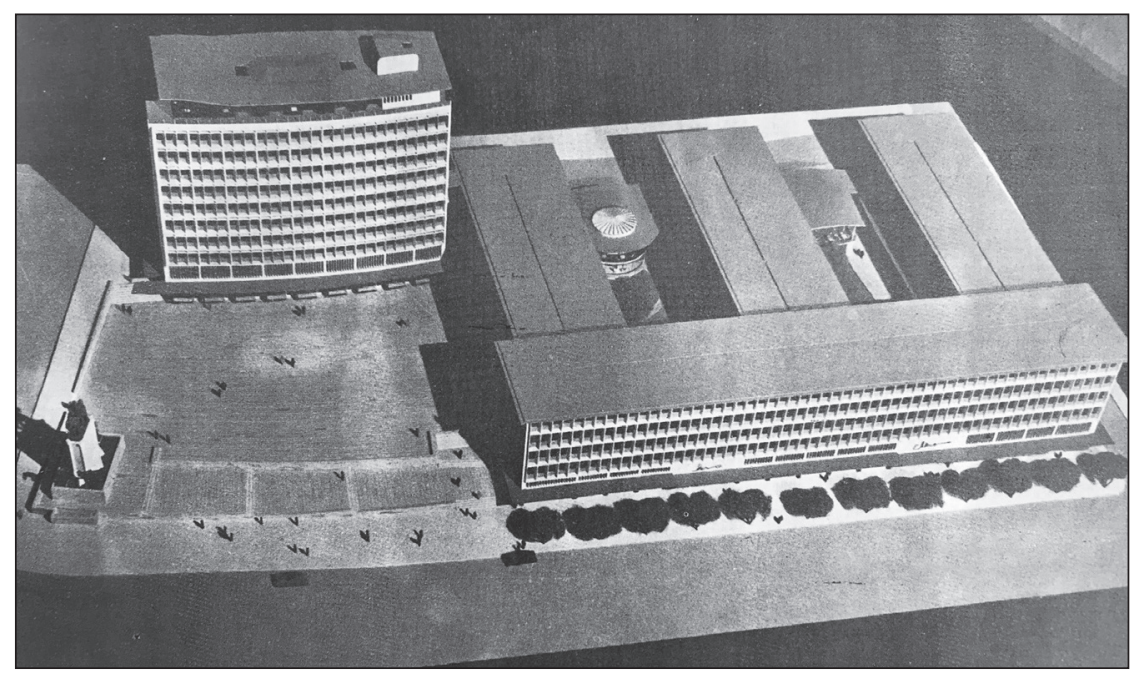

Figure 30. The building model of Ulus İşhanı ve Çarşısı project.

Source: Cengizkan and K1lıçkıran, 2009, p. 25. 
In 1954, an international competition for the development of a master plan for Ankara was announced. The winner of the competition in 1955 was the Turkish team of Nihat Yücel and Raşit Uybadin, and the implementation process started in 1957. However, it soon became apparent that the plan was based on inaccurate projections of the future population growth of the city. ${ }^{53}$ It also contained insufficient proposals for newly developed areas and the emerging squatter areas surrounding the city, as well as did not pay attention to historic areas. Therefore, several problems arose due to the inexactness of the plan. When analysed, it can be seen that the Yücel-Uybadin Plan considered Kizılay not as a rapidly growing city centre, but as a sub-area that would be utilised in the future mainly for entertainment and small business facilities. It can therefore be stated that by not foreseeing the rapid development of Kizllay and the tendency of the city centre to shift from Ulus Square to Kizilay district, the Yücel-Uybadin Plan was inefficient to control and direct the complex urban relationships and development activities that took place in Ankara. As a result of this unsuitable plan, the late 1950s and early 1960s witnessed the arbitrary transformation of Ulus and Kizılay Squares.

Due to the urban policies developed and followed by the DP government between 1955 and 1965, activities to reorganize urban spaces increased extensively. These activities mainly concentrated in expropriations, demolitions and the construction of massive buildings and opening of wide roads. This conformed to the
DP's vision of an American city that consisted of wide roads, boulevards and squares filled with automobiles and skyscrapers. It was also promoted by DP as the ideal image of a contemporary city. In 1956, Istimlak Kanunu [the Law of Expropriation] was effectuated and utilised by the government and municipalities as a tool for demolishing existing urban tissue in a faster way and to legally expedite the opening of wide roads and construction of massive blocks that represented the prevailing urbanisation ideology. Main arteries of the city were widened and massive blocks were introduced to the city through a series of urban operations. While on one hand, these activities meant that the city adapted to the increase in population to a certain extent, on the other hand, it did represent a complete annihilation of the process that had begun with Jansen's plan (Tekeli, 1982, p. 71). Eventually, major part of the lands around Karaoğlan was demolished, and activities for re-organisation of the open spaces around Ulus İ̧̧hanı ve Çarşısı began.

As part of Ulus İşhanı ve Çarşısı project, a square shaped open space was proposed for pedestrians in between the northern part of the lower block and the higher block. The project also included the transfer of the Victory Monument from its original place at Karaoğlan to the north-west corner of this open area (Figure 31A and 31B). In 1960, lower blocks located on the southern part of Ulus İşhanı ve Çarşısı project (facing Bankalar Road) were constructed, followed by the completion in 1963 of higher block standing on the background of the

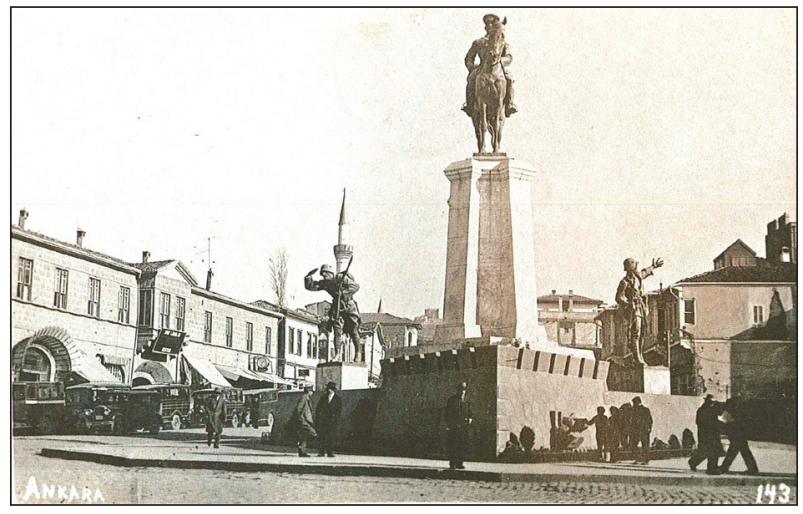

Figure 31A. Previous location of the monument, late 1920s. Source: Cangir, 2007, p. 839.

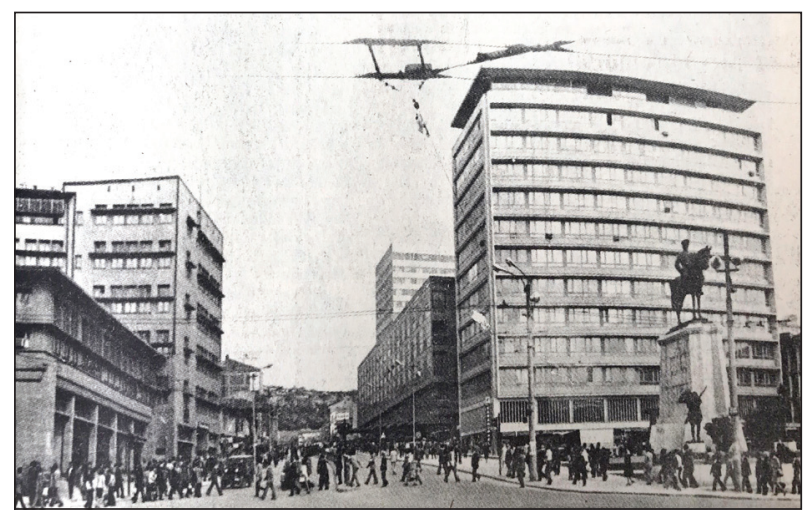

Figure 31B. After its transfer.

Source: 50 Yıllık Yaşantımız, 1975, p. 53.

53 The plan projected the population of Ankara being 750,000 by the year 2000. However, it had already reached this number by 1965 . 
Victory Monument. In a short period of time, additional to its architectural and urban space values, Ulus İşhanı ve Çarşısı became the main building within the area dominating the physical, functional, cultural and social attributes attached to the square during the 1960s.

Immediately following the opening of Ulus İşhanı ve Çarşısı, an architectural project competition was held for a commercial building to be constructed on the land located to the east of Karaoğlan, which had been cleared a The Law of Expropriation in 1956. The team of Ferzan Baydar, Affan Kırımlı and Tayfur Şahbaz won the competition, and their design Anafartalar Çarşısı [Anafartalar Bazaar] was constructed in 1967. The building was composed of two blocks, one a five-storey high shopping block, and the other a fifteen-storey high office block. Anafartalar Çarşısı was one of the first and the largest of the commercial buildings in Ulus district, which provided several types of shops for different user groups. It can therefore be considered as a pioneer of today's shopping malls (Ertemli, 2005). The way Anafartalar Çarşısı was situated in Karaoğlan, the height difference between the masses, and most importantly the building's relation to Ulus İşhanı ve Çarşısı, all had a significant impact on the unity of the buildings located at Ulus Square. At the same time, the similarity of design aspects reflected the architectural trends of Turkey during the 1960s (Figure 32A, 32B and 32C).

The final architectural competition was held for 100. Yll Çarşısı $\left[100^{\text {th }}\right.$ Year Bazaar], for the land located at the corner of Atatürk Boulevard and Cumhuriyet Boulevard which was previously occupied by Millet Garden. The team of Semra Dikel and Orhan Dikel won the competition in 1967. The construction process of 100. Yıl Çarşısı took almost fifteen years and the building complex, which was composed of a lower and a higher block with commercial and office units, as well as a cinema, was opened in 1982 (Figure 33A and 33B). Both due to its design, materials and construction techniques, and as is the case with Ulus

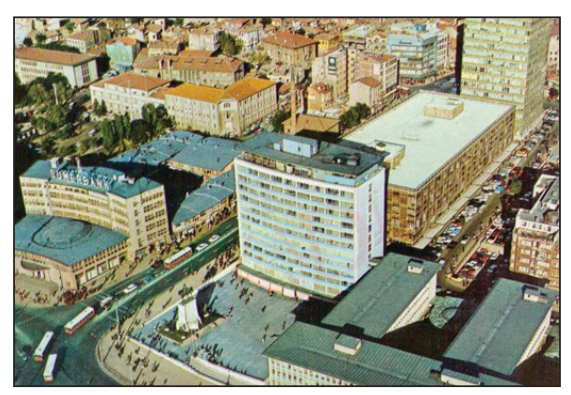

Figure 32A. Ulus Square; Ulus İşhanı ve Çarşısı and Anafartalar Çarşısı. Source: Cengizkan and Kılıçkıran, 2009, p. 16.

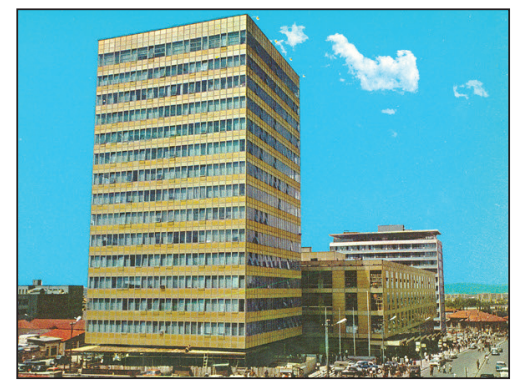

Figure 32B. The construction of Anafartalar Çarşısı, office block. Source: VEKAM Library and Archive, Inventory no. 2548.

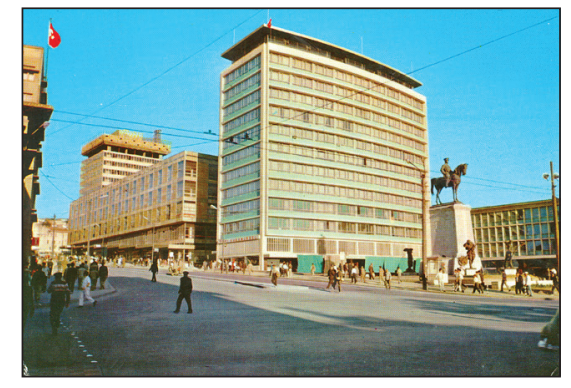

Figure 32C. Anafartalar Çarşısı. Source: VEKAM Library and Archive, Inventory no. 2579.

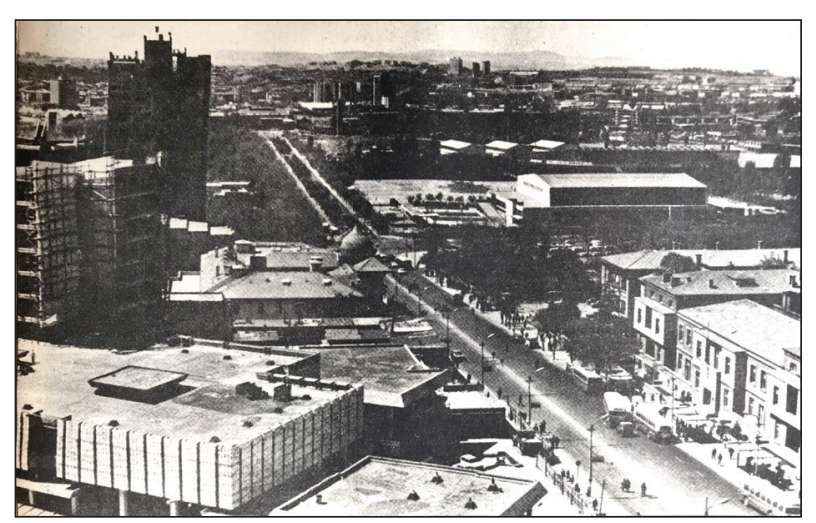

Figure 33A. Construction site of 100. Yıl Çarşısı, early 1970s. Source: 50 Yıllık Yaşantımız, 1975, p. 55.

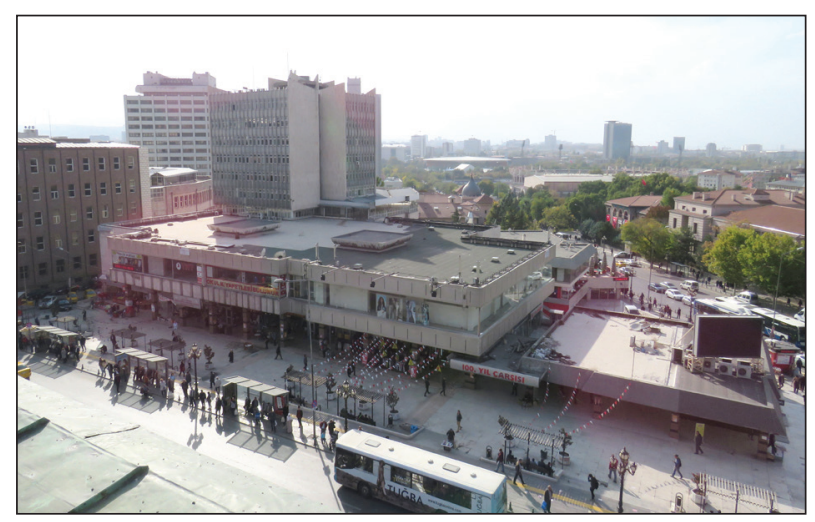

Figure 33B. 100. Yil Çarşısı, 2017.

Photograph by: Elif Selena Ayhan Koçyiğit. 
İşhanı ve Çarşısı and Anafartalar Çarşısı, 100. Yıl Çarşısı can be considered as a significant interpretation of the international architectural styles seen in Turkey during the 1960 s. ${ }^{54}$

After the construction of Ulus İşhanı ve Çarşısı, Anafartalar Çarşısı and 100. Yıl Çarşısı, Ulus Square gained a new physical, functional and visual presence in comparison with previous decades. First, the similarity of the architectural aspects of these buildings created a visual continuity for Ulus Square. All three building designs had a successful composition of masses with diverse architectural aspects (a high and low block with different widths). At the same time, their level and width differences, as well as the contrast and variety they provided to the square, created visual interest and gave a more legible character to the area. Moreover, the location of these buildings, and how they were situated on the land, radically changed the characteristics of the edge, territory and form of Ulus Square that had not been defined clearly in previous decades. With the construction of higher and massive buildings around the Square, the ratio of the width of the space to the height of buildings changed completely, and the feeling of enclosure within the square increased. Even though all three building complexes were composed of massive blocks, their fragmented design increased permeability within the square that had a direct and positive affect on the usage intensity and pedestrian flow. On the other hand, due to the lack of an efficient development plan for Ankara, the life span of these buildings and their impact on regenerating the declining appeal of Ulus Square was quite brief.

In addition to construction activities, there were other events, which also radically affected the user profile and function of Ulus Square. In 1961, twenty-three years after the sod turning ceremony, the third building of the National Assembly located in Kizılay district was completed. With the opening of the new assembly, the one located in Ulus Square and several other associated buildings and areas lost their meaning for the city. ${ }^{55}$ Parallel to this change, Ankara Palas, which was utilised as the main hotel of the state, also lost its importance. Especially the opening of Grand Ankara Hotel at Atatürk Boulevard next to the Third Assembly complex repeated the reciprocal relationship between the First and Second National Assemblies and Ankara Palas (Balamir and Erkmen, 2006, p. 96) (Figure 34). Furthermore, between the years of 1960 and 1970, offices, ministry buildings and administrative institutions progressively transferred their head offices to Kizılay district. ${ }^{56}$

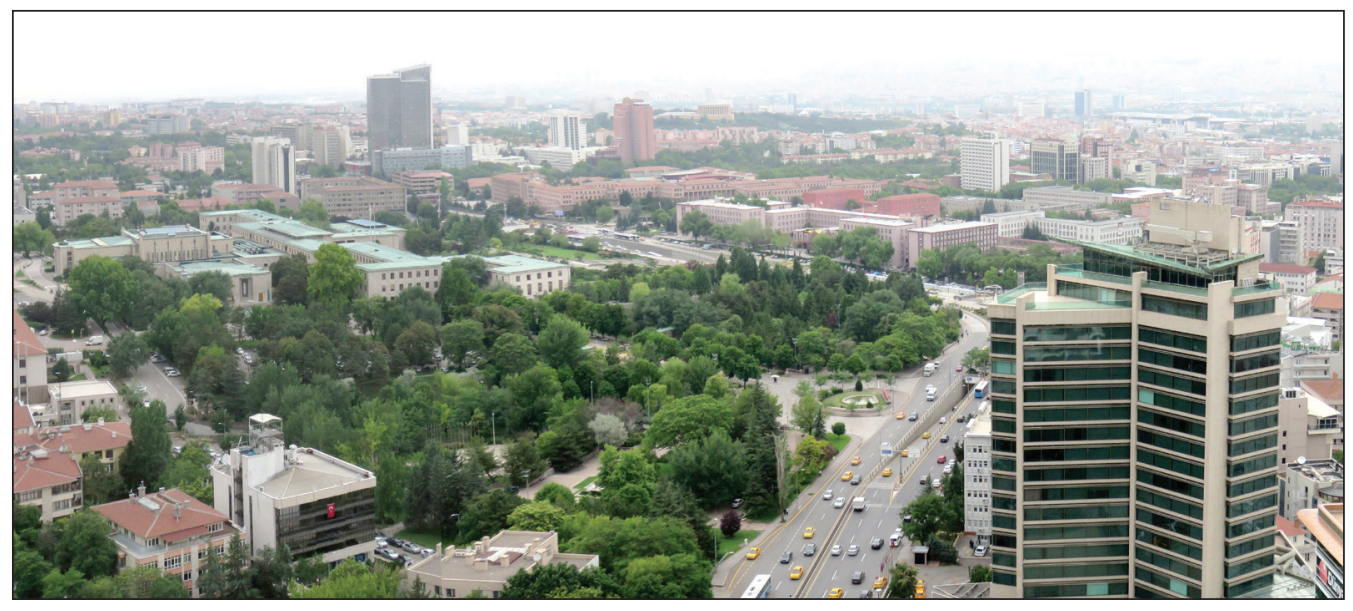

Figure 34. The Third National Assembly and the Grand Ankara Hotel facing each other, 2018. Photograph by: Elif Selena Ayhan Koçyiğit.

54 Starting in the 1950s, different concepts, styles and ideas on architecture emerged as an outcome of the democratisation process of the country. These styles, most of which originated in the West, can be summarised as: rationalist-purist, brutalist, independent, and the reinterpretation of traditional architectural aspects (Sözen, 1984, p.276).

55 Rüzgarlı Street was the main location of Ankara where most of the press were concentrated during the 1950s (Şenol Cantek, 2012, p.467), since it was the closest location to the assembly. After the opening of the Third National Assembly building in the Kizilay district, the popularity of Rüzgarlı Street decreased, and most of the press houses and newspapers transferred their offices from Ulus area to Kızllay (Öymen, 2009, p.524).

56 During the 1950s, beginning first with the Prime Ministry and later with the Ministry of Finance, several administrative buildings gradually moved to their new buildings located in Bakanlıklar and Yenişehir districts. 
Even though the master plan of Yücel-Uybadin placed Ulus Square as the main city centre, as a predictable consequence of the above-mentioned events, the late 1960s witnessed a gradual decline of Ulus Square and the relocation of several functions from Ulus to Kizılay. In parallel with this decline, a socio-cultural transformation of the user groups and how the area was utilised also started to change. This decline was also accelerated by the urban laws and regulations issued during this period. First, Kat Mülkiyeti Kanunu [The Condominium Law/ Law of Property] was issued in 1965, and plans of Bölge Kat Nizamı [District Height Regulation] were modified in 1968. Over a short period of time, the physical aspects of the main arteries, urban squares and the streets of Ankara started to be accordingly transformed, and there was a significant increase in urban density without the control of a development plan.

Depending on the district, the location and the width of the streets and roads, maximum number of floors permitted being increased from eight to ten storeys (and in some cases, thirteen storey buildings were also approved) (Figure 35A and 35B). Moreover, this latter change in regulation also increased the number of applications seeking to combine small building lots to increase the floor area, and this resulted in the construction of massive blocks, which contrasted with the existing urban environment. Due to insufficient protection of the existing urban environment, or detailed study of the social and technical infrastructural needs of the city, the approval of these plans resulted in the rapid physical transformation of existing urban spaces, especially in the main arteries

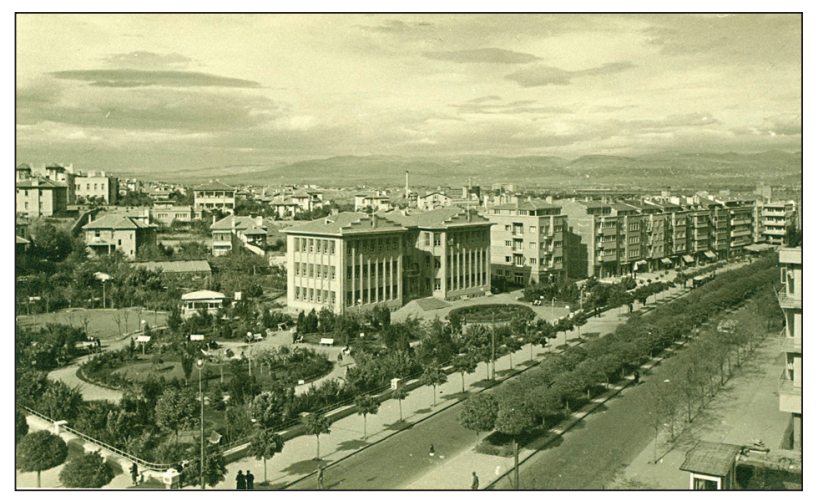

Figure 35A. The view of Atatürk Boulevard from Kızılay Square, 1940s.

Source: VEKAM Library and Archive, Inventory no. 0655. and public open spaces of Ankara. As a result, the process eventually led to a total replacement of the urban fabric, where the model contemporary city lost its values in the favour of a more chaotic order (Günay, 2012).

As an outcome of the rapid increase in the number and density of buildings in Ankara, the number of pedestrians that regularly used the city's boulevards and roads correspondingly increased. In response to the rising demand for public transportation in Ankara, the municipality increased the number of buses, but the problem remained. The bus stops all around Ulus and Kizilay Square were overcrowded and filled with people waiting in long queues. Even when the passengers managed to board a bus, the journey itself was often a nightmare. Due to an increase in the number of public transportation vehicles in operation, a need arose for additional bus, dolmuş and minibus stops within Ulus Square and its close vicinity. As a consequence, many green areas were partially demolished and converted into public transportation stops, thus accelerating the transformation of Ulus Square from an urban square into a transportation hub (Figure 36).

As mentioned previously, even though several commercial and office buildings were constructed within Ulus Square, these additions only allowed the area to briefly maintain its importance. While the core of the square had the chance to be partially revived, it could not escape becoming the main commercial area for the vast amount of population composed of low-income groups with agricultural backgrounds (Şenyapilı, 1985, p. 164). Between 1960s

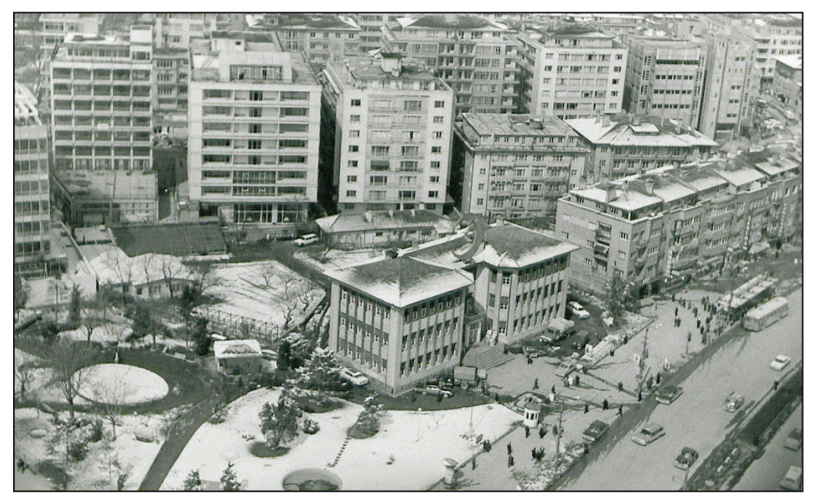

Figure 35B. Tall and massive buildings were erected along Atatürk Boulevard, 1968.

Source: VEKAM Library and Archive, Inventory no. 2908. 


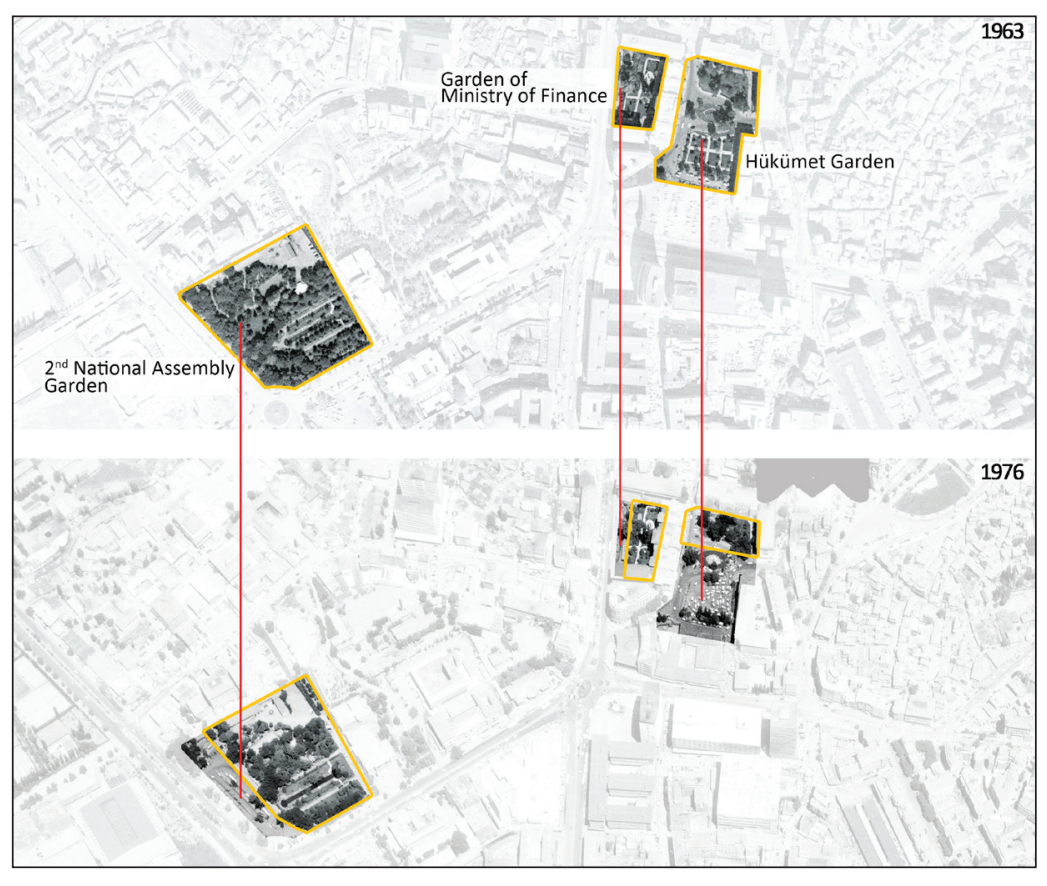

Figure 36. Partial transformation of the green open spaces in Ulus Square into public transportation stops, between 1963 and 1976.

Source: Author, labelled on aerial photos of 1963 and 1976, General Directorate of Mapping. and 1970s, most of the well-known brands located in the Ulus district either closed their shops one after the other and moved their business to Kizılay, ${ }^{57}$ or they opened a new main branch in Kizılay and downgraded their old Ulus branch. Due to land prices, the concentration of commercial and leisure time activities, and the prices of rental houses ${ }^{58}$, the popularity of Kizllay increased day by day. Furthermore, as it had become the central area for public transportation vehicles operating between the centre and peripheries, ${ }^{59}$ Ulus Square became the first stop for the residents of squatter areas to spend their leisure time in Ankara and search for work. As a result of these events, the inevitable transformation of the user profile of Ulus Square and the area's socio-cultural structure began. Ulus Square, which had been the central shopping area for high-quality products for decades, gradually transformed into the main location for budget shopping. In her novel, Ramazanoğlu clearly expressed the difference between Kizılay and Ulus in the 1970s in terms of the quality of shops:
Even though they bought a tie, a shirt for Peter and dresses, and necklaces for the girls, they were all wrapped with packages showing that they were bought from the shops of Kizılay. Only people living in Ankara could understand this. How could a German man understand the difference... Yet, still they insisted on explaining to him that the gifts were all bought from Kızılay, not from Ulus or Dışkapı (2008, p. 154).

Due to the relocation of the main administrative, commercial and financial functions, which had previously determined the character of Ulus Square, there was a significant decline in the usage of the area, both for leisure time and daily activities, by high-income groups and notable figures of the period. With the change in the average income and status of the people who frequented the area, it was not long before the shops and businesses of Ulus Square changed to fit the requirements of the new user groups. This change started in the late 1950s, became

57 The owner of one of the most famous shops of Ankara, Ayhan Mağazası, recalls that while the shop was still located in the Ulus district, many of their customers asked them to relocate their shop by saying; "You should really come to Kizllay, you should come here." As a result, the store decided to move to Kızılay area in 1969 (Sümer, 2012, p.220).

58 Öymen emphasises that rental places in Kizllay were extremely costly when he was a newlywed and searching for a place close to the newspaper that he was working for $(2013$, p.85).

59 Minibus routes connected squatter areas to the city and were therefore mainly used by lower-income groups. The main stations of minibus routes were located in Ulus district. On the contrary, most of the dolmuş routes were concentrated in Kızllay and used by middle-income groups. There were virtually no dolmuş routes connecting Kızllay to the squatter areas (Akçura, 1971, p.93). 
dominant during 1970s, and was particularly noticeable in the way the main leisure time activity places, such as the restaurants, bars, and gazinos of Ulus Square and its close vicinity adopted themselves to changing demands. During the same period, Ulus Square, which had gained its administrative function starting from the Ottoman period, lost its political meaning and importance for Ankara. Eventually, the triangular area defined by Kizllay-Sihhiye-Cebeci became the new political centre of the city (Özkök, 1990, p. 119).

\section{Overall Context of Ulus Square and Its Close Vicinity in the 1980s}

The shift of the city centre from Ulus Square to Kizılay Square during the 1960s resulted in an increase in the importance of Kizılay compared to Ulus by the end of the
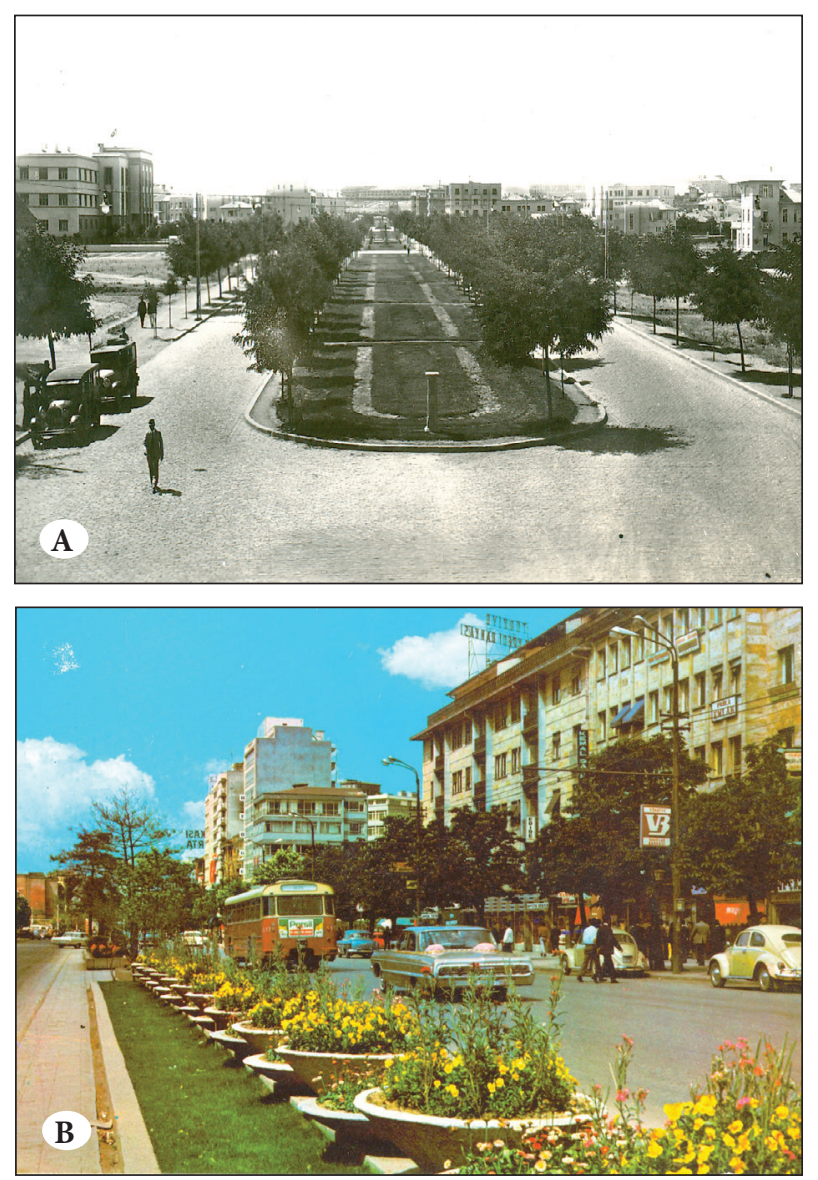

Figure 37. Transformation of Atatürk Boulevard, around Zafer Square. A. 1930s (Source: VEKAM Library and Archive, Inventory no. 0886). B. Early 1980s (Source: VEKAM Library and Archive, Inventory no. 2648). decade. Starting from the 1970s onwards, Kizılay became the main central area for the city due to its concentration of commercial, financial, administrative and leisure activities. Ulus, on the other hand, was mainly utilised by low-income groups for commercial and leisure activities, and also by officials working in the public institutions and banks that remained in the area. Moreover, following the radical changes in building height and mass regulations, Ulus Square, its close vicinity and the northern parts of Atatürk Boulevard as the emergence point of Republican Ankara, were transformed into a crowded traffic node. There was an increase in boulevard width from $30 \mathrm{~m}$ to $50 \mathrm{~m}$ with the demolishment of the central green median refuge and the addition of wide sidewalks on both sides (Batuman, 2017, p. 67) (Figure 37A and 37B).

All of the changes that were implemented, the reduction in green areas, the cutting down of trees to widen the roads, the increase in building heights and masses, and the increase in the density of buildings and population, took place in an area where no analytic studies were done regarding infrastructure. As a result, Ulus Square and its close vicinity was surrounded by an extremely dense urban tissue. Cars and motor vehicles dominated the area and almost no public open space was left for the residents of Ankara to socialise (Figure 38) ${ }^{60}$

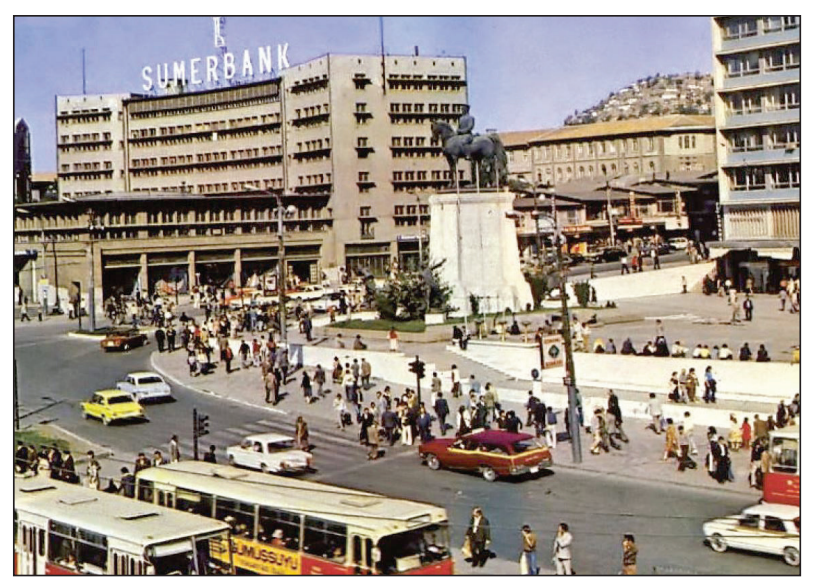

Figure 38. Ulus Square, 1980s.

Source: Kaya, 2007, p. 23.

60 According to Batuman, the main factor that destroyed the square as a social space was the elimination of public open green areas that allowed predefined practices/activities (2017, p.67). 


\section{The First Conservation Plan of Historic Ankara and its Impact on Ulus Square}

According to Günay, in late 1960s planning environment was much better equipped through the experiences gained from previous decades (2012). In this context, the Ankara Metropolitan Alan Nazım Plan Bürosu (AMANP) [Ankara Metropolitan Area Master Plan Bureau] ${ }^{61}$ prepared the 1990 Master Plan, with the plan being approved in 1982. The main aim of this strategic plan was to prevent the negative impacts of land speculations and the implementations of District Height Regulation Plans on the urban fabric of Ankara. Most importantly, this plan acknowledged that Ulus was more important than Kizılay, making allowances for it being the main core of the city centre and that it was more likely to see the future spatial development services (Bademli, 1987, p. 158).

Even though the plan had several important proposals to mitigate the negative impacts of previous periods, the implementation process of the plan was often interrupted in the 1990s due to the pressure of the state and local authorities. This meant that the urban development of the city continued to be negatively impacted by frequent random development projects. Ulus lost its remaining business service character for the city with the transfer of most activities from Ulus to the Eskişehir Road. ${ }^{62}$ The northern parts of Ulus Square became surrounded by low-income residents and transition zone activities, whereas the southern part of the centre became surrounded by high-income residents, embassies, foreign representatives and public institutions (Gökçe, 2008, p. 129). With the effect of the laws encouraging an increase in building height, a considerable number of the existing buildings were replaced by tall and massive blocks. By the end of 1990s, most of the buildings located at the main axis of Ankara, such as Atatürk Boulevard and Çankırı Road were replaced with new blocks (Figure 39A and 39B). As a result of the vehicle and construction-oriented policies of the municipality, most urban activities and the implementations of this period resulted in negative impacts in terms of the loss of authenticity and the integrity of public open spaces in Ankara, especially in Ulus Square.

During the implementation of the 1990 Ankara Master Plan, several other developments in the field of conservation took place in Turkey. Even though the understanding of conservation radically changed and improved between the 1960s and the 1990s, its impact on the urban fabric of Ulus Square and its close vicinity
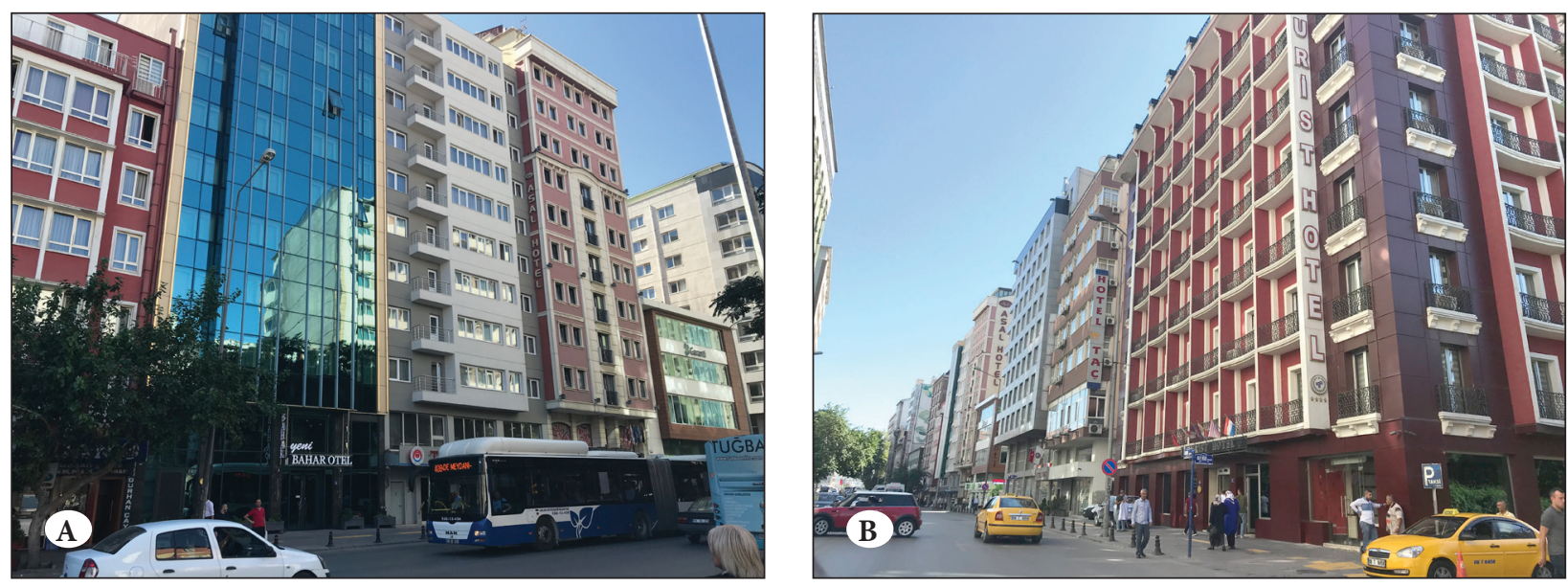

Figure 39A and 39B. Çankırı Road, 2018.

Photograph by: Elif Selena Ayhan Koçyiğit.

61 The planning bureau was directed by Haluk Alatan and Özcan Altaban, who were both city planners with an architectural background. Most of the bureau members were mainly graduates of the Middle East Technical University, The Department of City and Regional Planning.

62 Even though Ulus continued to maintain its traditional character based on consumer services, it became difficult to define this area as being a CBD. Most of the business-based activities had already moved from Ulus to Kızılay during the 1970s, later in the 1980s to Kavaklıdere-ÇankayaGOP area, and finally to Eskişehir Road in the 1990s. 
was limited. In 1980, for the first time in Ankara, the boundaries of urban and archaeological sites were defined, ${ }^{63}$ implementation and construction activities regarding the urban development plan were stopped, and the registration of cultural assets within these areas was accelerated. On the other hand, a major part of Ulus Square and its close vicinity was not included in these boundaries. Even though the preparation of this map can be considered as being an important beginning regarding the conservation of historic Ankara in its entirety, in terms of the case of Ulus Square and its close vicinity, it was hard to define this period as being an attempt to maintain the continuity of values attached to the area throughout its history.

Following the definitions of the urban and archaeological site boundaries, the Ankara Municipality Urban Planning and Development Directorate organized a competition

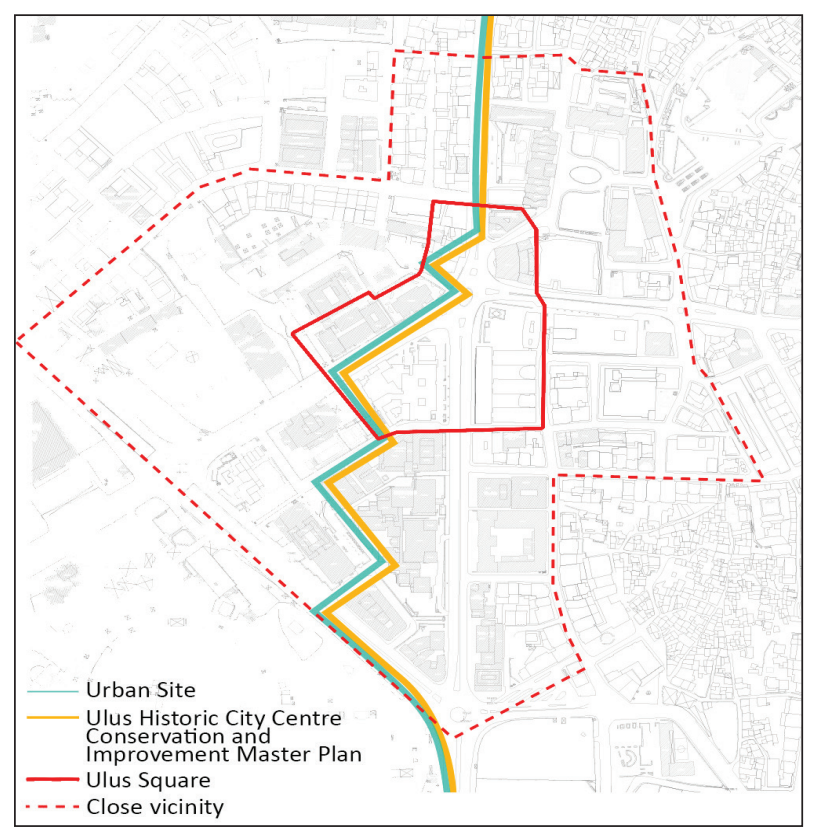

Figure 40A. Boundaries of the urban site, and the conservation master plan around Ulus Square and its close vicinity.

Source: Author, labelled on basemap of Ankara, 2015. in 1986, which was won by a team from Middle East Technical University (METU). ${ }^{64}$ Their proposal, Ulus Tarihi Kent Merkezi Koruma Islah Imar Planı [Ulus Historic City Centre Conservation and Rehabilitation Master Plan] was approved in 1989 and put into force in 1990. As can be seen in Figure 40A, Ulus Square and its close vicinity were only partially included within the conservation master plan area. It is therefore difficult to claim that this plan had a significant impact on Ulus Square and its close vicinity in its entirety. Several Kamu Proje Alanı (KPA) [Public Project Area] were proposed as a part of the conservation plan, of which KPA- 5 covered an area containing Ulus Square, Hükümet Square and the streets aligned between these two public open spaces (Figure 40B). Proposed as an urban design project integrating the two main squares through pedestrian areas, KPA-5 was an important attempt to reduce the

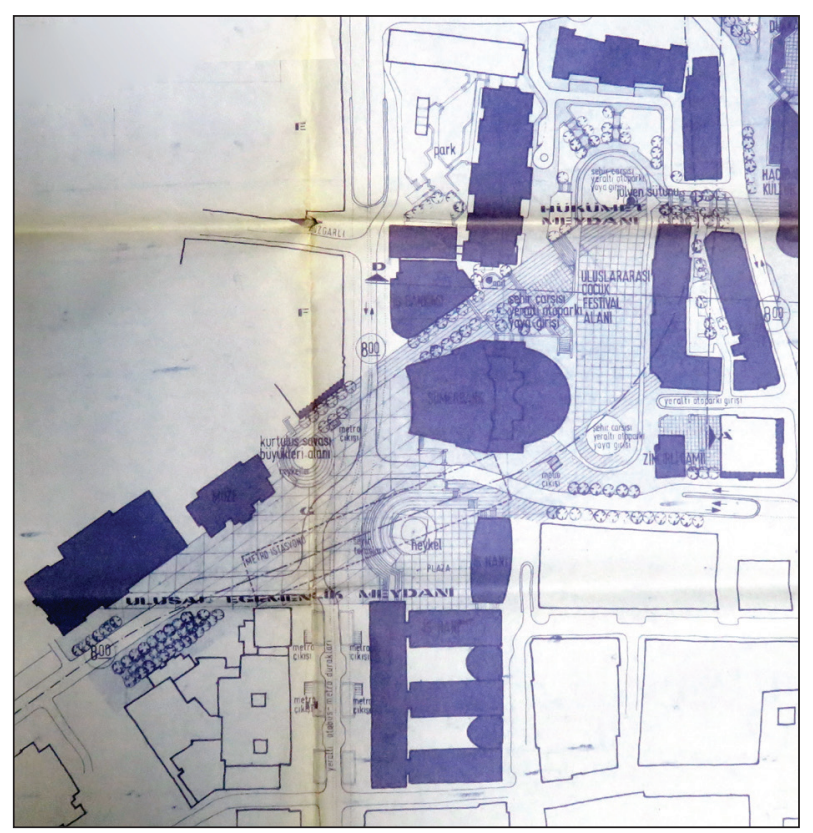

Figure 40B. Ulus Historic City Centre Conservation and Rehabilitation Master Plan, KPA-5.

Source: Ankara Yenileme Alanı Kültür ve Tabiat Varlıklarını Koruma Bölge Kurulu Archive, File no. 13103040/165.02/ 06.00-1, 12 .

63 Boundaries of the sites defined in 1980 (n.A-2167) were updated in 1985 (n.1378) and 1986 (n.2458), but this had only a minor impact on Ulus Square and its close vicinity.

64 Team Members: R. Raci Bademli (team leader), City Planning Team: Ömer H. Kıral, Baykan Günay, Funda Erkal, Zeki K. Ülkenli, Can Kubin, Deniz Altay, Neriman Şahin, Ertuğrul Morçöl, Yeşim Nalcıŏlu; Architectural Team: Abdi Güzer, Çiğdem Tacal, Korkut Onaran, Barış Eyikan; Urban Furniture Team: Mehmet Asatekin; Landscape Advisor: Alaaddin Egemen, Transportation Advisor: Rüştü Yüce. 
accelerated decline that Ulus Square had been facing for the last two decades. ${ }^{65}$ However, even though the project was approved, due to the repeal of the conservation master plan in 2005, it could not have the chance to be implemented. Therefore, the conservation plan and the projects it included had limited impact on Ulus Square compared to the rest of historic Ankara.

The regulations defined by the Ulus Historic City Centre Conservation and Rehabilitation Master Plan had a significant effect on the conservation of the site and the continuity of the values of historic Ankara. On the other hand, Ulus Square and its close vicinity only being partially included in the plan created several problems in ensuring the continuity and conservation of the area during the implementation process. Moreover, the random decisions made by local authorities in planning, development and transportation issues between 1990 and 2005 also gradually degraded the Square. The meaning of Ulus Square for Ankara was also affected by the changing user profile and how the square was utilised. A good example of the erosion on the Square's meaning was how the Victory Monument lost its significance and symbolic importance through time. The monument turned into an everyday object for the residents and it became commonly referred as Ulus Heykel [Ulus Monument] or just Heykel [Monument], rather the Victory Monument (Cengizkan and Kilıçkıran, 2009, p. 21). As profound changes in meaning emanate from radical functional and physical changes in the environment, the transformation of Ulus Square meant that the new users of the area did not attach the same meaning to the monument as previous users had (Figure 41A, 41B and 41C).
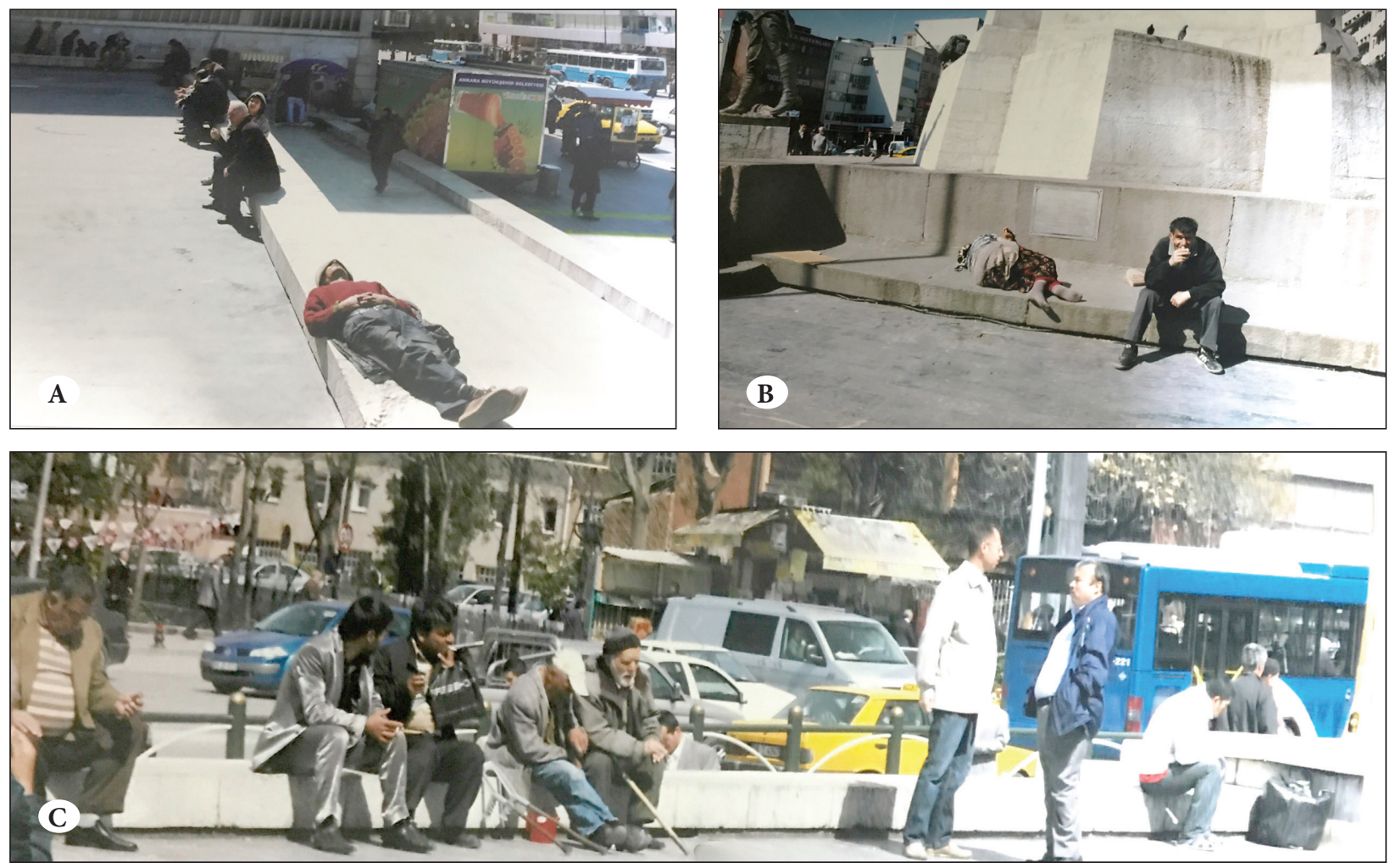

Figure 41A, B and C. Daily users of the square.

Source: Ankara Yenileme Alanı Kültür ve Tabiat Varlıklarını Koruma Bölge Kurulu Archive,

File no. 13103040/165.02/ 06.00-1, 22.

65 The project proposed several ideas to reorganize Ulus Square's spatial layout. A pedestrianisation project was proposed for the square, introducing a vehicular underpass, which would direct the traffic flow between Çankırı Road-Atatürk Boulevard and Cumhuriyet Boulevard-Anafartalar Road, together with metro stations and multi-storey car parking areas. For additional information, see Tunçer (2000, pp. 19-21). 
Consequently, the last decades have witnessed the gradual exclusion of pedestrians from public spaces and the loss of the physical, functional and socio-cultural identity of the areas. This has been mainly caused by the vehicle traffic oriented planning approaches of most of the state and local authorities. This has meant that, as a part of the development and transportation plans developed and implemented in previous periods, Ulus Square, like several other central squares and boulevards of the city, has turned into a chaotic traffic node where most of the vehicles and pedestrians are only passing through the area. The previous character of being a public open space has been largely lost.

\section{The Law on Conservation by Renovation ${ }^{66}$ and the Renovation Plan Developed for Historic Ankara}

From 2005 onwards, most of the values attached to the buildings and public open spaces of Ulus Square and its close vicinity have transformed, and the main physical, functional, socio-cultural and ideological aspects that had defined the area have been gradually diminishing. Among the main factors that created and accelerated the decline in identity in the area, of particular significance was the impact of laws and plans mainly developed as part of political ideologies.

Following the repeal of the Ulus Historic City Centre Conservation and Rehabilitation Master Plan, as well as of all other plans ${ }^{67}$ developed subsequently, by the Ankara Metropolitan Municipality (n.210) on 14 January 2005, the Law on Conservation by Renovation (n.5366) was enacted and became the main determinant for the future of historic areas in Turkey, as well as for historic Ankara. This law changed the status of local authorities and enabled them to intervene in the process of the conservation of historic areas. Furthermore, it also gave full authority to municipalities regarding the planning and implementation process developed for renovation areas defined by the law. This law can therefore be considered as a turning point, in a negative manner, for the conservation of heritage places in Turkey (Özçakır, Bilgin Altınöz and Mignosa, 2018, p. 3). Immediately following the enactment of 5366, the boundaries of the Renovation Area were defined by the Municipal Council in 2005 (n.1952) (Figure 42) ${ }^{68}$ and preparations for the development of a renovation plan for historic Ankara commenced immediately.

The Ankara Historic Urban Centre Renovation Area 1/5000 Conservation Master Plan, and the 1/1000 Conservation Implementation Plan, were prepared by HASSA Architecture Firm, and approved by the Ankara Renovation Area Council ${ }^{69}$ on 17 May 2007 (n.25) and by the Municipal Council on 15 June 2007 (n.1619). These plans were mainly focused on the values associated with

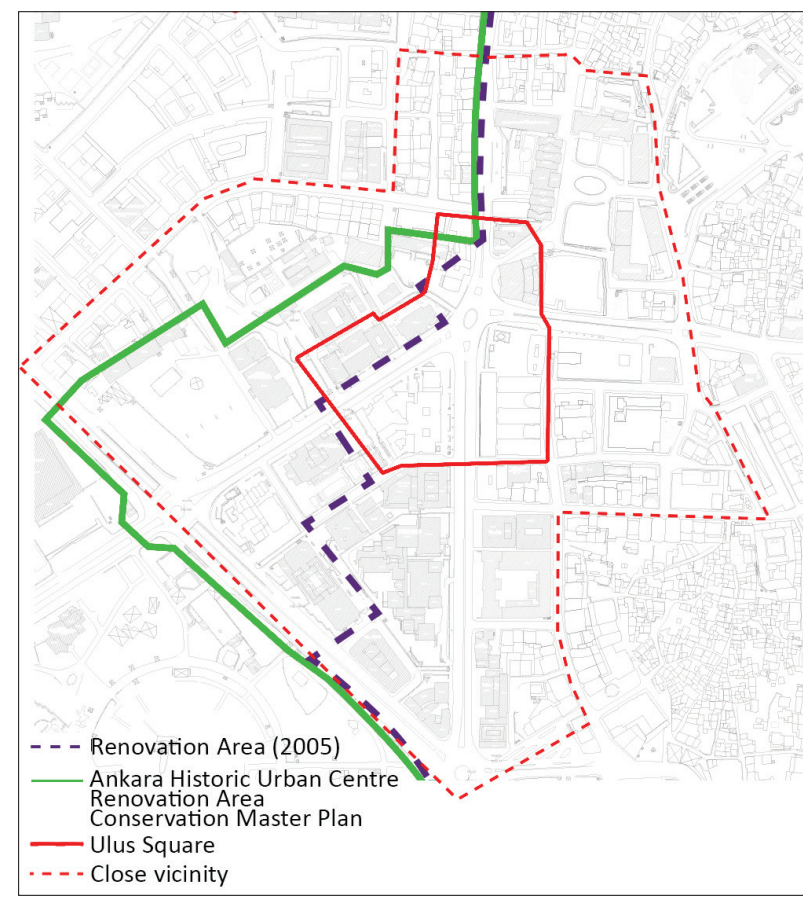

Figure 42. The boundaries of the renovation area, and renovation plan area around Ulus Square and its close vicinity. Source: Author, labelled on basemap of Ankara, 2015.

66 Yipranan Tarihi ve Kültürel Taşınmaz Varlıkların Yenilenerek Korunması ve Yaşatılarak Kullamılması Hakkında Kanun [Law on Conservation by Renovation and Use by Revitalization of the Deteriorated Historical and Cultural Immovable Property].

67 The Ankara Citadel Conservation and Rehabilitation Master Plan and Historic Urban Tissue Conservation Master Plan were also repealed.

68 In comparison to the boundaries of the previous conservation plan, the renovation area included the same parts of Ulus Square and its close vicinity. On the other hand, since the planning boundaries were defined for a wider area, it can be seen that almost every part of Ulus Square and its close vicinity is included in the boundaries of the renovation plan.

69 The Ankara Renovation Area Council for the Conservation of Cultural and Natural Heritage. 
the Seljukid, Ottoman and early Republican periods of Ankara. Most of the proposals developed by the plans were concentrated on revealing these values, whereas the physical, functional, visual, socio-cultural, political and ideological aspects attached to the other period were excluded either by demolition or by transformation. On the other hand, it is stated in the plan reports that one of the main aims of the plans is the refunctioning of abandoned areas by assigning commercial, touristic and cultural functions to traditional residential areas located in the centre of the historic city. In order to achieve this goal, the buildings to be restored or demolished (for reconstruction) were defined in detail and additional $1 / 500-1 / 200$ scaled urban design projects were also proposed (2006).

The urban design project developed for Ulus Square and its close vicinity proposed a complete change for the area through the demolishment of buildings specifically built during or after 1950s (Figure 43). This and other urban design projects developed as a part of the plan, were in complete contradiction with the fundamental principles of conservation, and therefore could only be defined as being proposals, which were aimed at urban regeneration (Tunçer, 2013, p. 15). For instance, a summary from the plan report, which explains the main approach of the renovation plan for Ulus Square and its close vicinity clearly proves this statement:

The Early Republican period buildings, and their relationship with their immediate surroundings, were re-evaluated for Ulus Square and Atatürk Boulevard, which is where these buildings are mainly concentrated. Regarding the crucial importance of Ulus Square for the history of the Republic, the plan aims at interpreting these spatial relationships though contemporary methods of design. Within this context, one of the main aims of the plan is defined as the revitalisation of Ulus Square, which covers the area defined by the First National Assembly, İş Bankası, Sümerbank, Ulus İşhanı ve Çarşısı, Merkez Bankası, Ankara Palas, the Second National Assembly and the Chamber of Accounts. In order to transform the existing traffic node image of Ulus Square from merely

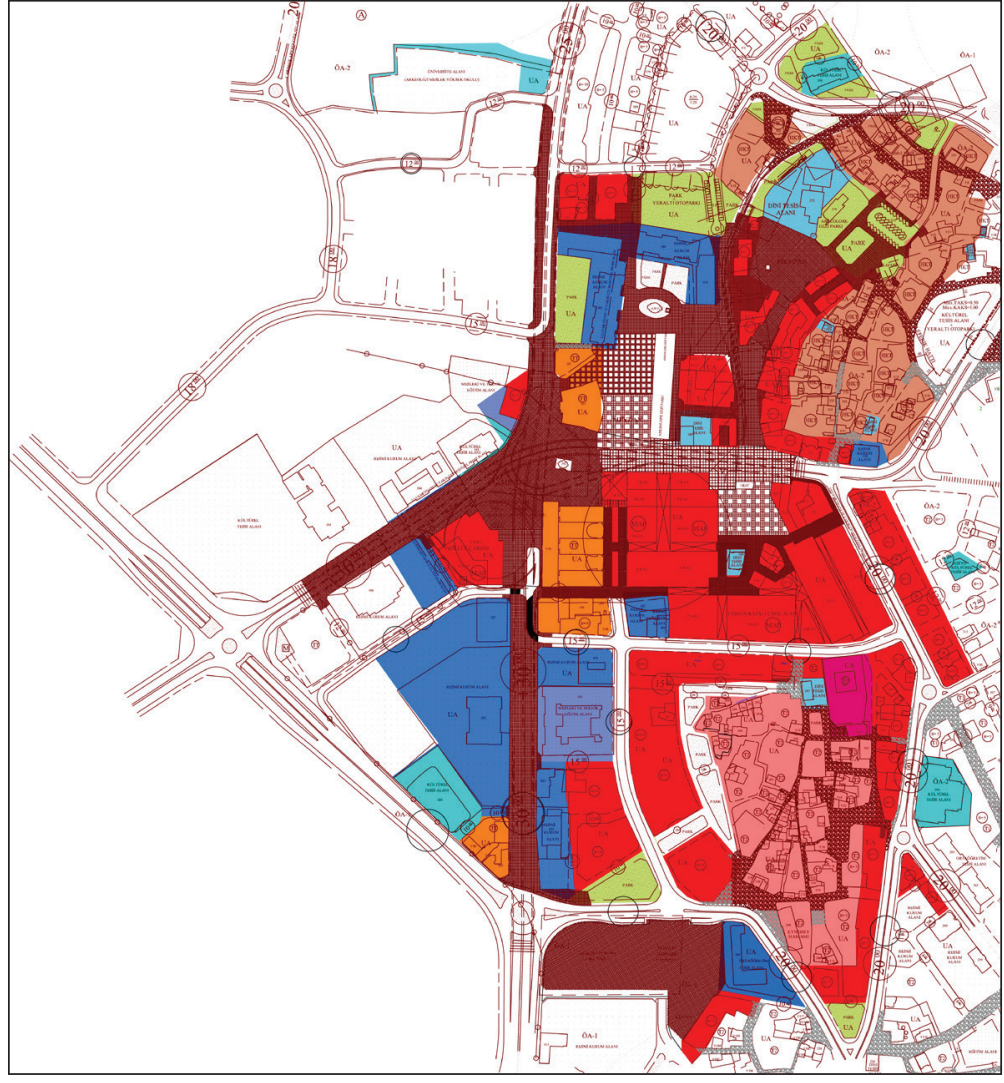

Figure 43. Detailed view of Ulus Square and its close vicinity in the Ankara Historic Urban Centre Renovation Area Conservation Master Plan.

Source: Ankara Tarihi Kent Merkezi Yenileme Alanı Koruma Amaçlı İmar Planı Açılama Raporu: Ekler, 2006. 
being the intersection of Atatürk Boulevard-Çankırı Road and Cumhuriyet Road-Anafartalar Road, the plan proposes a project to convert the roads into under passages, which will allow the implementation of a more pedestrianised urban square design. In addition to this, due to the projections of the plan in terms of the increase in the attractiveness of the area in the near future, several underground parking areas within the square are also proposed (2006, p. 96).

While some parts of the above statement has accurate descriptions such as the reference to the negative impacts of vehicular traffic on Ulus Square, and the need for a detailed study for pedestrianisation of the area, the solutions proposed by the plan are quite vague and lack detail. For instance, without conducting a comprehensive study on the Roman and Byzantine Periods of Ankara, it is impossible to be sure that installing under passageways at Ulus Square would not cause irreparable damage. Moreover, the second statement, which is paraphrased below, is entirely contrary to the fundamental principles, methodology and scientific standards of conservation as well as value definition and process of developing a conservation project:

Ulus Square gains its main spatial value from the buildings of the Early Republican period, and the buildings erected around the square after the 1950s contribute little to the square. Moreover, in some cases, it is determined that some of these buildings actually have a negative impact on the square.

Another subject of consideration is the historic visual relationship between Ulus Square and Ankara Citadel. It is a fact that, these high-rise buildings are clearly blocking the visual relationship between the CitadelUlus-Station. It is therefore proposed that the highrise public buildings and Anafartalar Çarşısı, all of which make a limited contribution to the square, are removed, and an open space system is proposed for the area. This will allow the establishment of a visual relationship between Ulus Square and the Citadel, as well as a physical relationship between the area and Hükümet Square (Ankara Tarihi Kent Merkezi
Yenileme Alanı Koruma Amaçlı İmar Planı Açıklama Raporu: Ekler 2006, p. 97).

The buildings described in the plan report as lacking value are: Ulus İşhanı ve Çarşısı, Anafartalar Çarşısı and 100. Yıl Çarşısı. These buildings are evaluated by most of the scholars and specialists in architecture and conservation as significant symbols of the period between 1950s and 1970s. According to Madran, Altan Ergut and Özgönül (2005), these buildings have heritage value for Ankara due to their importance as being rare examples of the architectural understanding of their period, their construction materials and techniques, and of their designs, which have been developed as the outcome of an architectural competition. Moreover, they have memory value for the residents of Ankara, and have an important place in the collective memory, everyday life and urban story of Ulus Square. ${ }^{70}$ Furthermore, additional to the proposals for the demolishment of existing buildings, the plan also aimed to reconstruct the image of Ulus Square in terms of a selected period (Ottoman and Early Republican). Hence, the plan's definition of these buildings as lacking value, and its proposal for demolishing these buildings to create space for the recreation of an imitated image of the past, is incompatible with the contemporary understanding of conservation. Physical reconstruction that permanently changes the character of the site should not be undertaken for the purpose of interpretation alone (ICOMOS-Ename, 2005, p. 37). Therefore, regarding the evolution of the understanding of conservation, both in the world and in Turkey, the value of definition and the reconstruction proposals of the plan contradict the principles of conservation and laws of the period.

The last section of the renovation plan report on Ulus Square focuses on the refunctioning process of the buildings that surrounded the Victory Monument. It was stated that, due to the strategic location of Ulus Square, the plan proposed several refunctionings for the area, such as the transformation of Ulus İşhanı ve Çarşısı into a hotel that would host cultural activities such as congresses and exhibitions (2006, pp. 97-98). In addition to these refunctionings, several other projects were also suggested

70 For detailed information, see the values defined in the report of the Chamber of Architects Ankara, prepared for the registration application (Madran, Altan Ergut and Özgönül, 2005). 
for the development of the commercial areas in historic Ankara. Among these projects, the ones located in the close vicinity of Ulus Square were summarised as: Taşhan Kapalı Çarşısı [Taşhan Closed Bazaar] ${ }^{71}$ to meet the commercial activities of groups with a different welfare status, and the redesigning of $\mathrm{Hal}$ in the form of an arasta. Moreover, passageways are proposed on the second and third floor of these buildings to sustain a physical continuity within the commercial system defined by the plan (2006, pp. 92-93).

The renovation plan developed by HASSA proposed urban works that included the demolition of buildings erected after the 1950s, the construction of additional buildings-public open spaces that imitated the OttomanSeljukid periods and neglected the Roman and Byzantine periods of Ankara, and it also assigned several buildings with incompatible functions that mostly served commercial facilities. Since it was almost entirely contrary to the principles and standards of cultural heritage conservation, several oppositions were aroused ${ }^{72}$ and eventually, following an expert report, the Ankara $10^{\text {th }}$ Administrative Court decided to repeal the renovation plan on 18 November 2008 (n.2008/2233). Even though the plan was repealed before its implementation, it is still possible to trace its impact on the projects prepared and implemented by the municipality between 2008 and 2018 .

\section{Ulus Square as a Heritage Place at Risk: Implementation of the Projects developed from the Proposals of an Invalid Renovation Plan}

The period between 2008 and 2018 witnessed numerous changes on the boundaries of urban and archaeological sites, as well as in conservation and renovation areas in Ankara. Moreover, due to the repeal of the Ankara Historic Urban Centre Renovation Area Conservation Master Plan, all urban activities in historic Ankara continued to be regulated according to the transition period principles and terms of use. These regulations were first defined in 2008 for conservation areas (urban and archaeological sites). Later, after the approval of the boundaries of the renovation area by the Council of Ministers in 2010, new transition period regulations were defined separately for renovation areas in urban sites, and for urban sites excluding renovation areas. Even though scholars and chambers criticised transition period regulations for encouraging construction activities, and for their lack of detailed explanations of conservation methods and process, they were continued to be utilised as the main framework for urban activities in historic Ankara until the approval of a new conservation master plan. ${ }^{73}$

Since 2015, no other plan has been implemented for the conservation of historic Ankara. Furthermore, the historic parts of the city are being altered randomly through minor and major implementation projects directed by the framework of transition period regulations. For instance, several places located within the boundaries of urban and archaeological sites such as The Citadel, Hamamönü $^{74}$ and Hacibayram ${ }^{75}$ have undergone a rapid transformation process caused by building and street scale implementation projects, with no planning guidance (Avcı Hosanlı and Bilgin Altınöz, 2016, p. 94). In addition to these, several monumental and residential buildings have been demolished ${ }^{76}$ or scheduled to be demolished, regardless of whether they were registered, ${ }^{77}$

71 In the 1/1000 plan notes, it was stated that a design will be developed to integrate Ulus Çarşısı, Ulus Square, registered buildings and Suluhan. New buildings (a maximum of five stories high with an additional three stories for underground parking) will be proposed for the area in the form of closed bazaar system composed of traditional Turkish hans (article 5.2.2).

72 Chamber of Architects Ankara, Chamber of City Planners Ankara, Chamber of Landscape Architects/ Ankara and reports of METU Faculty of Architecture and Gazi University Faculty of Architecture and Engineering.

73 A new conservation master plan “Ulus Tarihi Kent Merkezi, Kentsel Sit Alanı 1/5000 Koruma Amaçlı Nazım İmar Plan (KAİP) [Ulus Historic City Centre Urban Site 1/5000 Conservation Master Plan]" was prepared by the UTTA Planning Bureau in 2013 and approved by the Ankara KTVKK on 18 December 2013 (n.716). After the implementation of changes, the plan was re-approved in 2014. However, due to problematic approaches and several faulty decisions, the execution of the plan was suspended in 2015 and the plan was repealed in 2016. The plan was therefore not able to be implemented in Ankara.

74 See Azize Elif Sudan “The Role and Approach of Local Authorities in the Field of Conservation: Case Study in Hamamönü” (2012).

75 See Merve Demiröz "Causes and Effects of Urban Transformation Processes on The Cultural Heritage in Hacı Bayram Area, Ulus" (2015).

76 Iller Bankası, a registered public building dating back to the 1930s, was unlawfully demolished in 2017 to create space for the reorganisation project of Hergelen (İtfaiye) Square.

77 Activities for the demolishment of Anafartalar İşhanı-Office Block and 19 Mayıs Stadyumu started in July 2018. In addition to this, municipality also considered the demolishment of Ulus İşhanı, 100 Yıl Çarşısı, Hal and Hippodrome. 
and urban design projects have been implemented in selected parts of the historic city where reconstruction and refunctioning became the main tool.

As transition period regulations are still valid, most of the urban activities of the municipality are causing irreversible and radical changes in the values attached to Ulus Square and its close vicinity. Of particular concern, especially as they have been accelerated during the last three years, several implementation projects have been developed in reference to the proposals of the renovation plan that was repealed by the court decision of 2008. Even though the renovation plan is no longer valid, due to the gaps and indefinite explanations within the transition period regulations, the municipality continues to develop and implement projects according to the renovation plan. Statement of Mustafa Tuna, the mayor of Ankara in 2018, is quite significant in terms of the municipality's projections for historic Ankara:

The Ulus Project has been ongoing for almost 10-12 years, having been on the agenda since 2005. Part of the plan was the construction of under passageways for the main roads intersecting at Ulus Square, and the implementation of a public square to create a touristic area. Tangible progress has been made concerning this project. Today, notice for evacuation was sent to most of the shop owners. As soon as these shops have been emptied, the municipality will be able to commence implementation of the project (Gören, 2018).

As can be seen in the statements made by the former mayor, and in the animation developed for the pedestrianisation project of Ulus Square (Figure 44), the municipality continues to propose projects that reference an invalid renovation plan. Most importantly, a considerable number of these projects have been approved by the Ankara Renovation Area Council, and implemented one after another in historic Ankara. One of these projects that aims to re-organise Ulus Square by demolishing buildings erected after 1950s has became the municipality's main urban design project. To implement the plan, the municipality first made an agreement with Sosyal Sigortalar Kurumu (SGK) [Social Security Institution], the owner of Anafartalar Çarşısı, Ulus İşhanı ve Çarşısı (higher and lower blocks) and the public open space around the Victory Monument, to transfer these properties in return of lands owned by the municipality. This allowed the municipality to eliminate one of the major obstacles in the demolition of several symbolic buildings in Ulus Square. Even though the Chamber of Architects Ankara, the Chamber of City Planners Ankara, as well as several initiatives and scholars, have all opposed the demolishment of Ulus İşhanı ve Çarşısı, Anafartalar Çarşısı and 100. Yıl Çarşısı, there has been no pause in the municipality's activities. In 2018, the higher

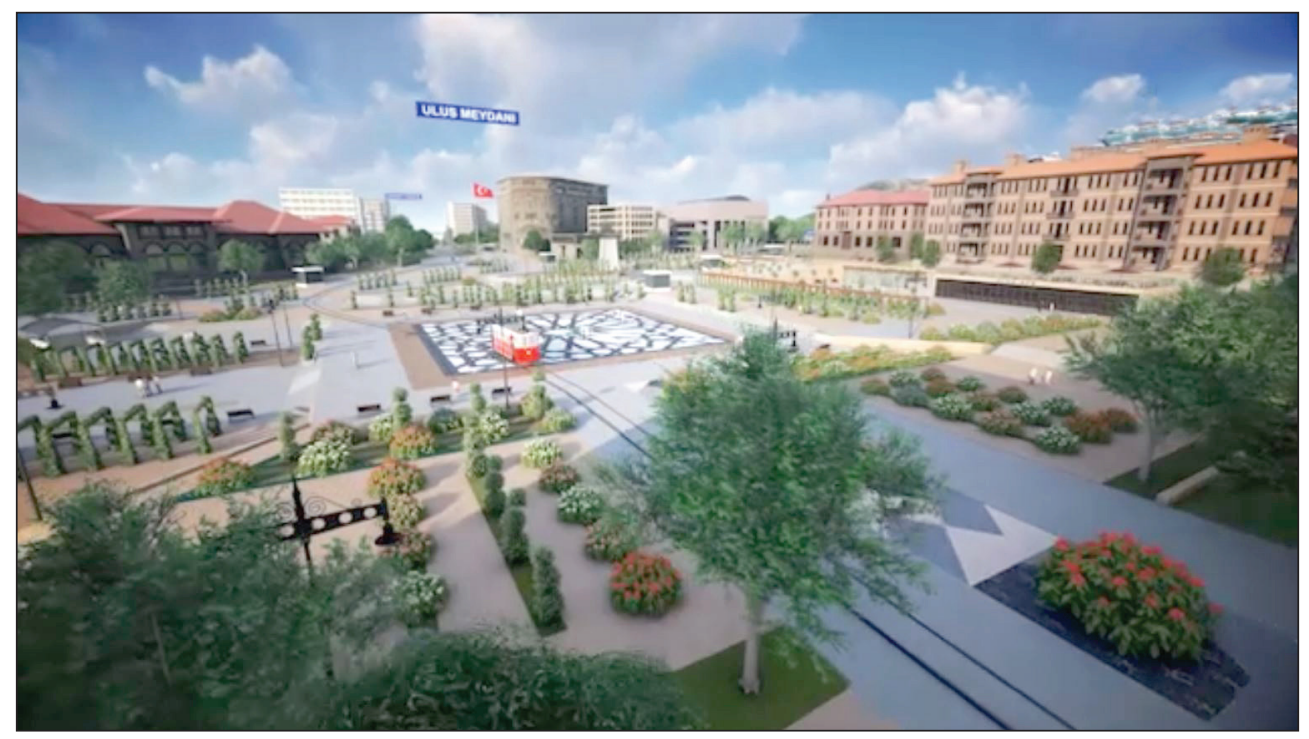

Figure 44. The pedestrianisation project proposed by the municipality for Ulus Square and its close vicinity, 2018.

Source: Ulus meydanında araç trafiği tamamen yerin altına alınacak, 2018. 
block of Anafartalar Çarşısı was demolished within one month (Figure 45A and 45B). ${ }^{78}$ By this way, the period for the demolition of existing urban fabric in order to create an imitated selected past, which has already started with projects implemented in Hamamönü, Hacıbayram and Hergelen Square, has been accelerated.

The last and significant change activated by the refunctioning works of Ankara Municipality, is concentrated on the buildings located in Hükümet Square, and its close vicinity. Except for Vilayet, ${ }^{79}$ the buildings surrounding Hükümet Square and Sümerbank have all been transferred to Ankara Sosyal Bilimler Üniversitesi [Social Sciences University of Ankara]. Moreover, Sümerbank is currently under restoration (Figure 46). This cultural heritage, which when it was constructed was a symbol of the move towards industrialisation of the early Repub-
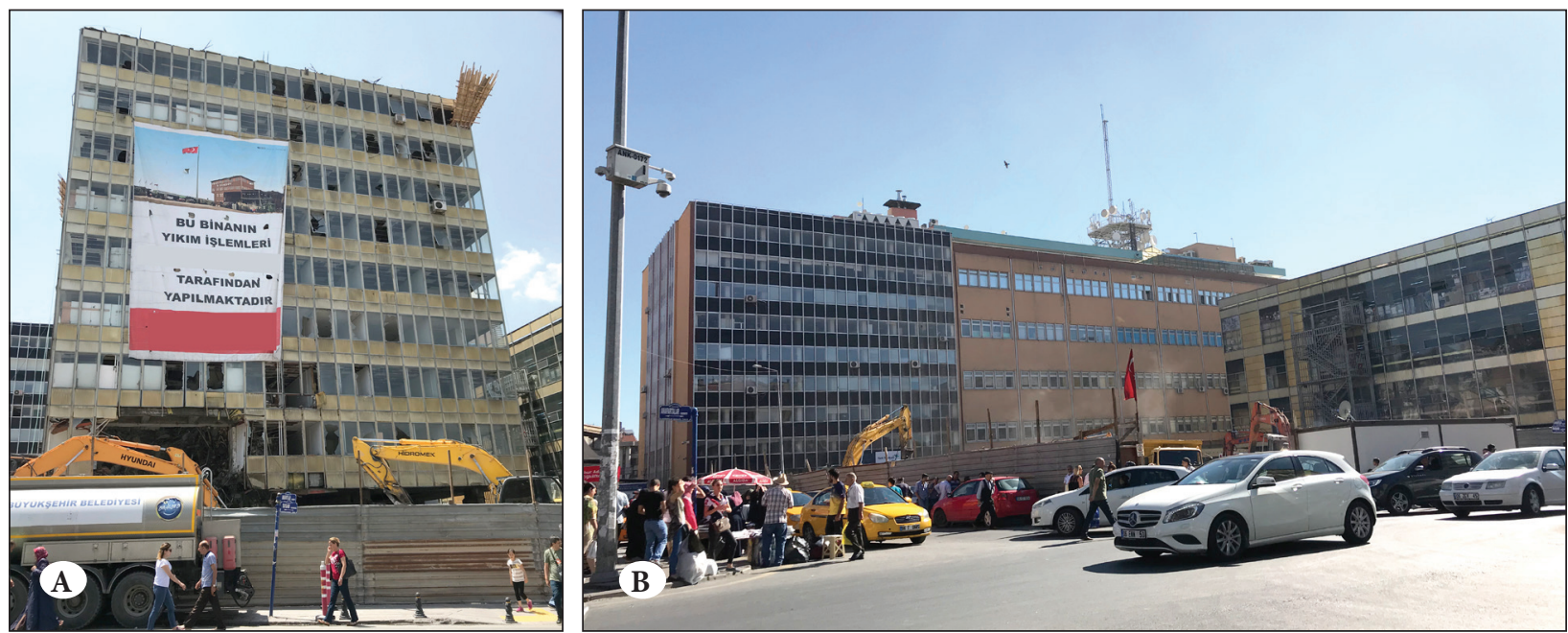

Figure 45. The demolition of the higher block of Anafartalar Çarşıs1 A. July 2018 B. August 2018.

Photograph by: Elif Selena Ayhan Koçyiğit.

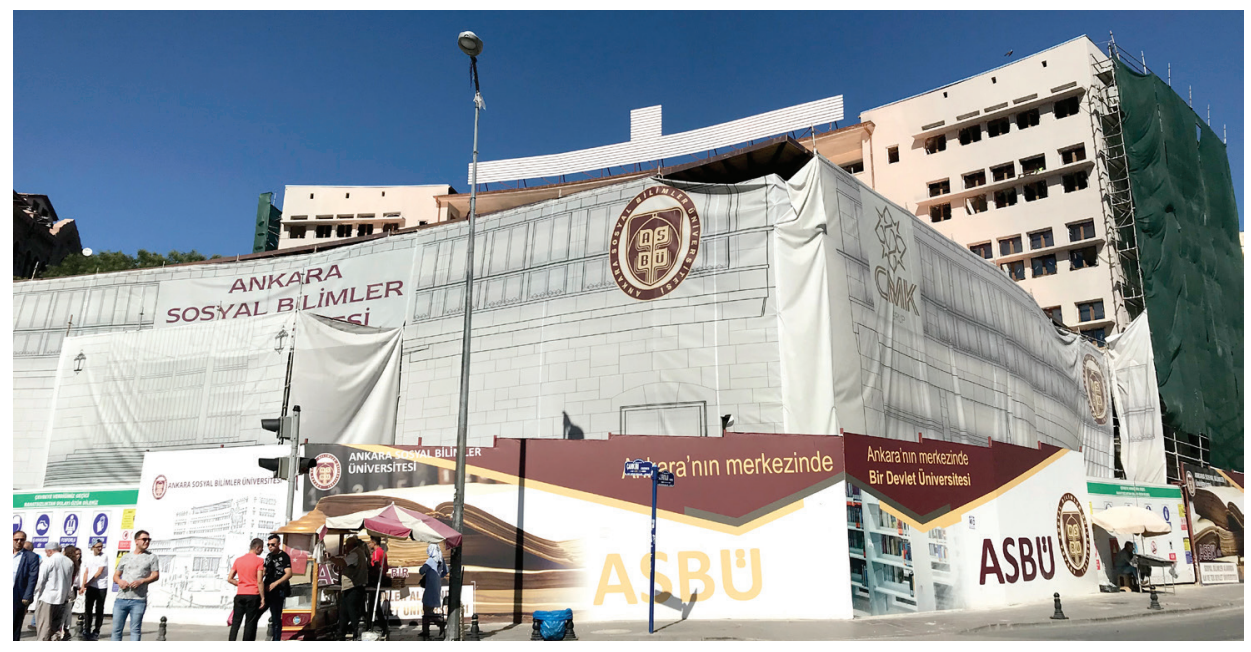

Figure 46. Sümerbank under restoration, 2018.

Photograph by: Elif Selena Ayhan Koçyiğit.

78 Mansur Yavaş was elected as the new mayor of Ankara Metropolitan Municipality on 31 March 2019. In May, Yavaş stated that Anafartalar Çarşısı has a significant value for Ankara and therefore the municipality decided to cancel the demolition of the remaining parts (lower block) of the building (Yllmaz, 2019).

79 The refunctioning of this building is scheduled for 2019. The president of the university, Prof. Dr. Mehmet Barca, stated that it is planned to transform the building into the "Ankara Museum of Administration" (Duyan, 2018). 
lican Period, and which has commercial, memory and socio-cultural value for the residents of Ankara, will have been transformed into a university campus building by the end of 2019. As a consequence of these functional and physical transformations, the administrative character of Hükümet Square, which emerged during the late Ottoman Period, will be replaced by educational facilities, and the significant heritage value of the area, which has been built up over centuries, will be gradually eroded.

\section{Conclusion}

Ulus Square embodies the values of several different periods, and thus has a significant role in the history of Ankara. As a public open space, the area emerged on the western base of the hill where the ancient city of Ancyra was settled. Established around 278 BCE by the Galatians, Ancyra was annexed to the Roman Empire in 25 BCE. As part of the Agora and being the site of the palace, "Ulus Square" was probably used for commercial, administrative and social activities during the Roman period. After Roman rule, Ankara constantly changed hands and eventually became part of the Ottoman Empire. In the late $19^{\text {th }}$ century, the importance of Ulus Square began to grow and it was transformed into the one and only public open square of Ankara. In the early $20^{\text {th }}$ century, Ankara became the operational centre of the War of Independence, and by hosting the First National Assembly, Ulus Square became the central location of Ankara. After the declaration of the Republic of Turkey, as well as Ankara as the new capital of the Republic, Ulus Square was transformed into a political, administrative, commercial, financial and entertainment centre. This was the beginning of a long period when Ulus Square continued to be used as the main public open space of the city. In the 1940s, however, the transformation process of Ulus Square started. Especially after the 1960s, with the implementation of projects focused on buildings and open spaces with new architectural styles, a new period began for Ulus Square and its close vicinity. Even though the area was still considered as being the main centre of Ankara, Kizılay gradually became more important for the city. As a result, by the end of 1970s, the gradual change in the physical, functional, socio-cultural and visual aspects of Ulus Square accelerated, and Ulus Square became the secondary centre for Ankara.

Even though Ulus Square was able to sustain its cultural significance for centuries, since 2005, rapid changes in the urban tissue of historic Ankara threaten the loss of Ulus Square's authenticity and integrity. Due to the role of current projects and plans developed by the state and local authorities on Ulus Square, the area is undergoing a radical and irreversible transformation process concentrated on demolition, reconstruction and refunctioning activities. In parallel to the change in physical and functional aspects of the Square, it is also possible to identify the loss of the socio-cultural values connected with the area.

To mitigate the negative impacts of irreversible change in Ulus Square, and to sustain the continuity of the cultural significance, there is an urgent need to develop conservation projects for the area. However, the lack of a detailed systematic framework and legislations defined for the conservation of historic public open spaces is still a major obstacle in Turkey. Most importantly, the role of value definition that is developed through a systematic historical analysis is not considered as being an inseparable part of conservation process by most local and state authorities. Therefore, without following a scientific method for the identification, analysis and evaluation of the values ascribed to the area, most of the projects implemented in historic public open spaces result in a loss of authenticity and integrity. To conclude, by conducting a detailed urban restitution study, this article aimed to reveal the values attached to Ulus Square and to identify the main factors that have caused or accelerated their change over time. This has allowed the telling of the story of Ulus Square based on the values attached to the area during different time periods, as well as raising awareness of the current vulnerability of the Square.

\section{References}

50 yıllık yaşantımız 1923-1933. (V. 1.) (1975). İstanbul: Milliyet. Aerial photo of Ulus [Photograph]. (1963). (Inventory no. 1362_456-1963). General Command of Mapping, Ankara.

Aerial photo of Ulus [Photograph]. (1976). (Inventory no. 3329_0136-1976). General Command of Mapping, Ankara.

Ankara tarihi kent merkezi yenileme alanı koruma amaçlı imar planı açıklama raporu. (2006). Hassa Mimarlık, Doruk Planlama.

Ankara posta kartları ve belge fotoğrafları arşivi. (1994). Ankara: BELKO.

Akçura, T. (1971). Ankara Türkiye Cumhuriyetinin başkenti hakkında monografik bir araştırma. Ankara: ODTÜ Mimarlık Fakültesi Yayınları. 
Aktürk, N. (Ed.). (2006). Fotoğraflarla dünden bugüne Ankara. Ankara: Milli Eğitim Bakanlığı.

Akurgal, E. (1994). Augustus Tapınağı ve Yazıtlar Kraliçesi. In E. Batur (Ed.). Ankara Ankara (pp. 33-50). İstanbul: Yap1 Kredi.

Alkan, M. Ö. (2015). Soğuk Savaş'in toplumsal, kültürel ve günlük hayatı inşa edilirken... In M. K. Kaynar (Ed.). Türkiye’nin 1950'li yılları (pp. 591-626). İstanbul: İletişim.

Anafartalar Çarşısı [Photograph]. Ankara Photograph, Postcard and Gravure Collection (Inventory no. 2579). Koç University VEKAM Library and Archive, Ankara.

Ankara City Map [Map]. (1924). Map and Plan Archive (Inventory no. H004). Koç University VEKAM Library and Archive, Ankara.

Ankara goat [Photograph]. (1920). Ankara Photograph, Postcard and Gravure Collection (Inventory no. 1550). Koç University VEKAM Library and Archive, Ankara.

Aslanoğlu, N. İ. (1994). Ankara'da yirmi yılın mimarlık değerlendirmesi: 1940-1960. In E. Batur (Ed.). Ankara Ankara (pp. 227-242). İstanbul: Yapı Kredi Yayınları.

Atay, F. R. (2010). Çankaya. İstanbul: Pozitif Yayınları.

Avcı Hosanlı, D., and Bilgin Altınöz, A. G. (2016) Ankara İstiklal (Yahudi) Mahallesi: Tarihi, dokusu ve konutları. TÜBA-KED, 14, 71-104.

Bademli, R. R. (1987). Ankara merkezi iş alanının gelişimi. ODTÜ Şehir ve Bölge Planlama Bölümü Çalışma Grubu, Ankara 1985'den 2015'e (pp. 154-162). Ankara: Ankara Büyükşehir Belediyesi EGO Genel Müdürlüğü.

Bademli, R. R. (1994). Ankara'da kent planlama deneyi ve ulaşılan Sonuçlar. In E. Batur (Ed.). Ankara Ankara (pp. 161-169). İstanbul: Yapı Kredi.

Bağlum, K. (1992). Beşbin yılda nereden nereye Ankara. Ankara.

Balamir, A., and Erkmen, A. (October 2006). Büyük Ankara Oteli'nin onarımı: Marc Saugey'nin tasarımını değiştirmeden. Arredamento Mimarlık, 10, 96-104.

Bankalar Road: Both sides filled with small shops [Photograph]. (1930). Ankara Photograph, Postcard and Gravure Collection (Inventory no. 1316). Koç University VEKAM Library and Archive, Ankara.

Batuman, B. (2008). Photography at arms: "Early Republican Ankara" from nation building to politics of nostalgia. METU JFA, 25(2), 99-117.

Batuman, B. (2017). Mekan, kimlik ve sosyal çatışma: Cumhuriyet'in kamusal mekanı olarak Kızılay Meydanı. In G. A. Sargın (Comp.). Başkent üzerine mekân-politik tezler: Ankara'nın kamusal yüzleri (pp. 41-76). İstanbul: İletişim.

Berggren, G. G. Kizılbey Complex, a detailed view of the fourth part of Vue genérale de la Ville d'Angora / Panoramic view of Ankara [Photograph]. (Serie N / n¹51 bis, 795196). Universite Bordeaux Montaigne, Fonds Paris.
Bozdoğan, S. (2001). Modernism and nation building. Singapore: University of Washington Press.

Broughton, T. R. S. (1938). An economic survey of ancient Rome IV: Roman Asia Minor. T. Frank (Ed.). Baltimore: John Hopkins University Press.

Buluç, S. (1994). İlkçağda Ankara. In E. Batur (Ed.). Ankara Ankara (pp. 21-32). İstanbul: Yapı Kredi.

Cangır, A. (Ed.). (2007). Cumhuriyetin başkenti. Ankara: Ankara Üniversitesi.

Cengizkan, A. (2004). Ankara'nın ilk planı: 1924-1925 Lörcher Planı. Ankara: Arkadaş.

Cengizkan, A., and Kilıçkıran, D. (2009). Yerin sesi, Ulus İşhaninın söyledikleri. Ankara: Arkadaş.

Celal Bayar, 30 yıl sonra Türkiye küçük bir Amerika olacak, dedi. (21.10.1957). Cumhuriyet, p. 1.

Daily users of the square [Photograph]. (2005). (File no. 13103040/165.02/ 06.00-1, 22). Ankara Yenileme Alanı Kültür ve Tabiat Varlıklarını Koruma Bölge Kurulu Archive, Ankara.

Darülmuallimin and Millet Garden [Photograph]. (1901). Ankara Photograph, Postcard and Gravure Collection (Inventory no. ACF0037). Koç University VEKAM Library and Archive, Ankara.

Demiröz, M. (2015). Causes and effects of urban transformation processes on the cultural heritage in Haci Bayram area, Ulus. Unpublished MSc dissertation. METU, The Graduate School of Natural and Applied Sciences, Ankara.

Dernschwam, H. (1987). Ístanbul ve Anadolu’ya seyahat günlüğ̈̈ (Y. Önen, Trans.). Ankara: Kültür ve Turizm Bakanlığı.

Dinçer, G. (2009). Ankara Atatürk Bulvarının öyküsü. In H. Ç. Keskinok (Ed.). Cumhuriyet Devriminin yolu Atatürk Bulvarı (pp. 11-36). Ankara: Koleksiyoncular Derneği.

During the construction of Anafartalar Çarşısı, office block [Photograph]. Ankara Photograph, Postcard and Gravure Collection (Inventory no. 2548). Koç University VEKAM Library and Archive, Ankara.

Duyan, U. (2018). 12 yeni müze. İlksayfa. Retrieved from www. gazeteilksayfa.com/12-yeni-muze-24898h.htm

Duyar-Kienast, U. (2005). The formation of gecekondu settlements in Turkey: the case of Ankara. Münster: LIT Verlag.

Ellison, G. M. (1973). Bir İngiliz kadını gözüyle Kuva-i Milliye Ankarası. İstanbul: Milliyet.

Erdoğan, A., and Günel, G. (2007). Ankara tarihi ve kültürü dizisi, 3: İstiklal Savaşında Ankara. Ankara: Ankara Büyükşehir Belediyesi.

Erdoğan, A., Günel, G., and Narince, M. (2007). Ankara tarihi ve kültürü dizisi, 4: Cumhuriyet ve başkent Ankara. Ankara: Ankara Büyükşehir Belediyesi.

Ergenç, Ö. (1995). 16. yüzyılda Ankara ve Konya. Ankara: Ankara Enstitüsü Vakfı. 
Ergir, Y. (2004). ANKARA 1920'ler ve ötesinden beriye. Düş Hekimi. Retrieved from www.ergir.com/Ankara.htm

Ergüven, E. (Ed.). (1938). Şükrü Kaya sözleri-yazıları 19271937. İstanbul: Cumhuriyet Matbaası.

Ertemli, M. (2005). Anafartalar Çarşısı ve İşhanı. Presented at Docomomo-tr Ulusal Çalışma Grubu Poster Sunuşları/ Türkiye Mimarlı̆̆ında Modernizmin Yerel Açılımları II, 1112 November 2005, İzmir.

Evliya Çelebi seyahatnamesi. (1970). İstanbul: Zuhuri Danışman Yayınevi.

Faroqhi, S. (1985). Mohair manufacture and mohair workshops in seventeenth - century Ankara. Ístanbul Üniversitesi İktisat Fakültesi Mecmuası, 41(1-4), 211-236.

Gökçe, B. (2008). Spatial dynamics of producer services in Ankara. Unpublished $\mathrm{PhD}$ dissertation. METU, The Graduate School of Natural and Applied Sciences, Ankara.

Gören, A. (2018). Ulus Meydani'na ilk kepçe. Sabah. Retrieved from www.sabah.com.tr/ankara-baskent/2018/05/20/ulusmeydanina-ilk-kepce

Gülekli, N. C., and Onaran, R. (1973). Türkiye Birinci Büyük Millet Meclisi 50. yıldönümü 1920-1970. İstanbul: Milli Eğitim Basımevi.

Günay, B. (2012). Ankara spatial history. Presented at Planning to Avoid: The $26^{\text {th }}$ AESOP Congress, 11-15 July 2012, Ankara.

Güven, S. (2001). Bir Roma eyaletinin evrim sürecinde Galatia ve Ancyra. In Y. Yavuz (Ed.). Tarih içinde Ankara II (pp. 109-122). Ankara: ODTÜ Mimarlık Fakültesi.

ICOMOS-Ename Charter for the Interpretation of Cultural Heritage Sites. (2005). [Revised Third Draft]. George Wright Society. Retrieved from www.georgewright. org/231 enamecharter.pdf

İlkin, S. (1994). Ankara’nın yeme-içme lokanta atılımının öncüsü: Karpiç Lokantası. Ankara Dergisi, 2(6), 65-71.

İmga, O. (2006). Tek partili dönemde Ankara. Ankara: Dipnot.

İstanbul Patisserie [Photograph]. Ankara Photograph, Postcard and Gravure Collection (Inventory no. 1486). Koç University VEKAM Library and Archive, Ankara.

İstasyon Road [Photograph]. (1930s). Levent Civelekoğlu Archive. Retrieved from http://lcivelekoglu.blogspot.com/

İş Bank, Sümerbank and the Victory Monument [Photograph]. (1940). Ankara Photograph, Postcard and Gravure Collection (Inventory no. 0846). Koç University VEKAM Library and Archive, Ankara.

İş Bank, Taşhan and the Victory Monument [Photograph]. (1931). Ankara Photograph, Postcard and Gravure Collection (Inventory no. 1207). Koç University VEKAM Library and Archive, Ankara.

İttihat ve Terakki Cemiyeti building [Photograph]. Ankara Photograph, Postcard and Gravure Collection (Inventory no. 0820). Koç University VEKAM Library and Archive, Ankara.
Kadıŏlu, M., and Görkay, K. (2008). Yeni arkeolojik araştırmalar ışı̆̆ında mhtpo Anadolu-Anatolia, 32, 21-151.

Karaosmanoğlu, Y. K. (2001). Ankara. İstanbul: İletişim.

Kaya, H. (2007). Ankara tarihi ve kültürü dizisi, 8: örnek başkent Ankara. Ankara: Ankara Büyükşehir Belediyesi.

Keyder, Ç. (1987). The political economy of Turkish democracy. In I. C. Schick and E. A. Tonak (Eds.). Turkey in transition (pp. 27-65). New York: Oxford University.

Kizılay Square: densely planted with trees [Photograph]. Ankara Photograph, Postcard and Gravure Collection (Inventory no. 1392). Koç University VEKAM Library and Archive, Ankara.

Kizılbey Road, increased its importance for Ankara and it was planted with trees accordingly [Photograph]. Ankara Photograph, Postcard and Gravure Collection (Inventory no. 2439). Koç University VEKAM Library and Archive, Ankara.

Koç, V. (1983). Hayat hikayem. İstanbul: Vehbi Koç Vakfı.

Kulin, A. O. (2002). Kominis nedir? In A. E. Bozyiğit (Ed.). Öykülerde Ankara (seçki) (pp. 219-226). Ankara: Kültür Bakanlığı.

Kuyulu Mosque [Photograph]. (1922). Ankara Photograph, Postcard and Gravure Collection (Inventory no. 2711). Koç University VEKAM Library and Archive, Ankara.

La Motraye, A. de. (1730). Travels through Europe, Asia, and into part of Africa... London: Mr. Round.

Lörcher Planı. (2010). Bir başkentin oluşumu. Goethe Institute. Retrieved from http://www.goethe.de/ins/tr/ank/prj/urs/ geb/sta/loe/trindex.htm

Lucas, P. (1712). Voyage du sieur Paul Lucas fait par ordre Du Roy Dans La Grece, L'Asie Mineure, La Macedoine et L'Afrique. Paris: Nicolas Simart.

Madran, E., Altan Ergut, E., and Özgönül, N. (2005). Mimarlar Odası raporu. Ankara: TMMOB Mimarlar Odası Ankara Şubesi.

Mamboury, E. (2014). Ankara gezi rehberi. Ankara: Ankara Üniversitesi Basımevi. (Original work published in 1934).

Memlük, Y. (2009). Bulvarın yeşil parçaları. In H. Ç. Keskinok (Ed.). Cumhuriyet Devriminin yolu Atatürk Bulvarı (pp. 7388). Ankara: Koleksiyoncular Derneği.

Military Barrack and Julian Column on the front [Postcard]. (1905). Ankara Photograph, Postcard and Gravure Collection (Inventory no. 0071). Koç University VEKAM Library and Archive, Ankara.

Opening ceremony of the monument [Photograph]. (1927). Ankara Photograph, Postcard and Gravure Collection (Inventory no. 0931). Koç University VEKAM Library and Archive, Ankara. 
Ortaylı, İ. (1984). Söyleşi: Osmanlı'dan bugüne hükümet konakları. [An interview with İnci Aslanoğlu, Baran İdil, Umut İnan, Merih Karaaslan, İlber Ortayl, Naci Özbek and Affan Yatman]. Mimarlık, 84(5), 3-15.

Ortaylı, İ. (2000). 19. yüzyıl Ankara’sına demiryolunun gelişi, hinterlandının ve hinterlandındaki üretim eylemlerinin değişimi. In A. T. Yavuz (Ed.). Tarih içinde Ankara I (pp. 207-220). Ankara: ODTÜ Mimarlık Fakültesi.

Önder, M. (2013). Milli Mücadele'nin gazetesi Hakimiyet-i Milliye nasıl çıkarıldı? TC Başbakanlık Atatürk Kültür, Dil ve Tarih Yüksek Kurumu/ Atatürk Araştırma Merkezi. Retrieved from www.atam.gov.tr/dergi/sayi-20/millimucadelenin-gazetesi-hakimiyet-i-milliye-nasil-cikarildi

Önen, B. Z. (Ed.). (2004). 80 yılda devri Türkiye, 80 kare Ankara. Ankara: VEKAM.

Öymen, A. (2009). Öfkeli yıllar. İstanbul: Doğan Kitap.

Öymen, A. (2013). Ve ihtilal. İstanbul: Doğan Kitap.

Özçakır, Ö., Bilgin Altınöz, G., and Mignosa, A. (2018). Political economy of renewal of heritage places in Turkey. METU JFA, 35(2), 221-250. DOI: 10.4305/METU.JFA.2018.1.10.

Özel, M. (Ed.). (2001). Atatürk. Ankara: Kültür Bakanlı̆̆ı.

Özkök, E. (1990). 68 gençliğinin Ankara’sı. In Başkent söyleşileri (pp. 113-126). Ankara: Kent-Koop Yayınları.

Poujoulat, B. (1841). Voyage a Contantinople, dans l'Asie mineure, en Mésopotamie, a Palmyre, en Syrie, en Palestine et en Égypte. Bruxells.

Ramazanoğlu, Y. (2008). Anglika’nın Ankara’yı unutuşu. In E. Dervişoğlu (Ed.). Kadın öykülerinde Ankara (pp. 151-170). İstanbul: Sel Yayıncilık.

Sarıoğlu, M. (1995). Bir vefa borcu: Taşhan. Kebikeç, 1, 185-192.

Sarığlu, M. (2001) Ankara bir modernleşme öyküsü (19191945). Ankara: Kültür Bakanlığı.

Scott, J. C. (1998). Seeing like a state: How certain schemes to improve the human condition have failed. New Haven: Yale University.

Small shops, on the north of Darülmuallimin [Photograph]. (1925). Ankara Photograph, Postcard and Gravure Collection (Inventory no. ACF0373). Koç University VEKAM Library and Archive, Ankara.

Small shops, on the north of Darülmuallimin [Photograph]. (1925-1926). Ankara Photograph, Postcard and Gravure Collection (Inventory no. 0767). Koç University VEKAM Library and Archive, Ankara.

Sof producers and merchants [Photograph]. Ankara Photograph, Postcard and Gravure Collection (Inventory no. 0763). Koç University VEKAM Library and Archive, Ankara.

Southern parts of Uznçarşı [Photograph]. (1920). Ankara Photograph, Postcard and Gravure Collection (Inventory no. 0884). Koç University VEKAM Library and Archive, Ankara.
Sözen, M. (1984). Cumhuriyet dönemi Türk mimarlığı, 1923-83. Ankara: Türkiye İş Bankası Kültür Yayınları.

Station Square: General Directorate of State Railways, The Central Train Station and Gar Gazinosu [Photograph]. (1939). Ankara Photograph, Postcard and Gravure Collection (Inventory no. 0758). Koç University VEKAM Library and Archive, Ankara.

Streit, A. C. K. (2011). Bilinmeyen Türkler: Mustafa Kemal Paşa, milliyetçi Ankara ve Anadolu'da gündelik hayat Ocak-Mart 1921. İstanbul: Bahçeşehir Üniversitesi.

Sudan, A. E. (2012). The role and approach of local authorities in the field of conservation: case study in Hamamönü. Unpublished MSc dissertation. METU, The Graduate School of Natural and Applied Sciences, Ankara.

Sümer, A. (2012). Bir Ankara markası: Ayhan Mağazası. In F. Şenol Cantek (Ed.). Cumhuriyet'in ütopyası: Ankara (pp. 217-222). Ankara: Ankara Üniversitesi.

Svetovski, M. Ankara, the heart of new Turkey. (07.01.1936). Ulus, pp. 1-4.

Şapolyo, E. B. (1967). Mustafa Kemal Paşa ve Milli Mücadelenin iç âlemi. İstanbul: İnkılap ve Aka Kitabevleri.

Şapolyo, E. B. (1969). Mustafa Kemal ve Birinci Büyük Millet Meclisi tarihçesi. Ankara: Ülkemiz.

Şenol Cantek, F. (2003). “Yaban”lar ve yerliler: başkent olma sürecinde Ankara. İstanbul: İletişim.

Şenol Cantek, F. (2012). Matris, kurşun kokusu ve simit... Başkent gazeteciliğinin memba1: Rüzgârlı Sokak. In F. Şenol Cantek (Ed.). Cumhuriyet'in Ütopyast: Ankara (pp. 467478). Ankara: Ankara Üniversitesi.

Şenyapıll, T. (1985). Ankara kentinde gecekondu gelişimi (19231960). Ankara: Batıkent Konut Üretim Yapı Kooperatifleri Birliği.

Şerif, A. (1977). Anadolu'da Tanin. İstanbul: Kavram.

Şimşir, B. N. (2006). Ankara... Ankara... Bir başkentin doğuşu. Ankara: Bilgi.

Tall and massive buildings were erected along Atatürk Boulevard [Photograph]. (1968). Ankara Photograph, Postcard and Gravure Collection (Inventory no. 2908). Koç University VEKAM Library and Archive, Ankara.

Tanyeli, U. (1987). Anadolu Türk kentinde fiziksel yapının evrim süreci. Published $\mathrm{PhD}$ dissertation. İTÜ, Mimarlık Fakültesi Baskı Atölyesi, İstanbul.

Tanyer, T. (2009). Social life in Ankara (1923-1938). In E. Işın (Ed.). Ankara: city of the black calpac 1923-1938 (pp. 129162). İstanbul: İstanbul Research Institute.

Taşhan [Photograph]. (1931). Ankara Photograph, Postcard and Gravure Collection (Inventory no. 1687). Koç University VEKAM Library and Archive, Ankara. 
Taşhan at Karaoğlan [Photograph]. (1890’s). Ankara Photograph, Postcard and Gravure Collection (Inventory no. 0975). Koç University VEKAM Library and Archive, Ankara.

Tekcan, A. R. (Ed.). (2014). Eski Ankara fotoğraf albümü. Ankara: Ankara Büyükşehir Belediyesi.

Tekeli, İ. (1978). Cumhuriyet döneminde (1923-1973) Türkiyede belediyeciliğin evrimi. In E. Türkcan (Ed.). Türkiye’de belediyeciliğin evrimi (pp. 27-311). Ankara: Türk İdareciler Derneği.

Tekeli, İ. (1982). Türkiye'de kentleşme yazıları. Ankara: Turhan Kitabevi.

Tekeli, İ. (1994). Ankara'da tarih içinde sanayinin gelişimi ve mekânsal farklılaşması. In E. Batur (Ed.). Ankara Ankara (pp. 171-199). İstanbul: Yap1 Kredi.

Tekeli, İ. (2000). Ankara’nın başkentlik kararının ülkesel mekân organizasyonu ve toplumsal yapıya etkileri bakımından genel bir değerlendirilmesi. In A. Tükel Yavuz (Ed.). Tarih içinde Ankara I (pp. 317-335). Ankara: ODTÜ Mimarlık Fakültesi.

Tekeli, İ., and Okyay, T. (1981). Dolmuşun öyküsü. Ankara: Çevre ve Mimarlık Bilimleri Derneği.

The view of Atatürk Boulevard from Kizılay Square [Photograph]. (1940s). Ankara Photograph, Postcard and Gravure Collection (Inventory no. 0655). Koç University VEKAM Library and Archive, Ankara.

Timur, T. (1987). The Ottoman heritage. In I. C. Schick and E. A. Tonak (Eds.). Turkey in transition (pp. 3-26). New York: Oxford University.

Tournefort, J. P. de. (1717). Relation d'un voyage du levant, fait par ordre du Roy. Paris: Impr. Royale.

Transformation of İstasyon Road, before road works [Photograph]. (1920s). Département Estampes et photographie, EI-13 (1058) (Identifier: ark:/12148/ btv1b53119802t). Bibliothèque nationale de France. Retrieved from http://catalogue.bnf.fr/ark:/12148/ cb44488759w

Transformation of Atatürk Boulevard, around Zafer Square [Photograph]. (1930s). Ankara Photograph, Postcard and Gravure Collection (Inventory no. 0886). Koç University VEKAM Library and Archive, Ankara.

Transformation of Atatürk Boulevard, around Zafer Square [Photograph]. (1980s). Ankara Photograph, Postcard and Gravure Collection (Inventory no. 2648). Koç University VEKAM Library and Archive, Ankara.

Tunçer, M. (2000). Tarihsel çevre koruma politikaları Ankara. Ankara: Kültür Bakanlığı.

Tunçer, M. (2001). Ankara (Angora) şehri merkez gelişimi (14.20. yy). Ankara: Kültür Bakanlığı.
Tunçer, M. (2013). Ankara Tarihi Kent Merkezi Yenileme Alanı Koruma Planı, niteliği ve iptaline ilişkin gerekçeler. Ankara Araştırmaları Dergisi, 1(2), 10-34.

Uludağ, Z. (2005). Geçen modern zamanların ardından: Kaybolan anlamlar. TMMOB Mimarlar Odası Ankara Şubesi BÜLTEN, 31: Modernleşme sürecinde Ankara ve Cumhuriyet kentleri, 30-32.

Ulus Historic City Centre Conservation and Rehabilitation MasterPlan,KPA-5 [Plan].(1989).(Fileno.13103040/165.02/ 06.00-1, 12). Ankara Yenileme Alanı Kültür ve Tabiat Varlıklarını Koruma Bölge Kurulu Archive, Ankara.

Ulus meydanında araç trafiği tamamen yerin altına alınacak. (2018). TRT Haber. Retrieved from www.trthaber.com/ haber/gundem/ulus-meydaninda-arac-trafigi-tamamenyerin-altina-alinacak-385600.html/

Üstün, S. (1997). Turkey and the Marshall Plan: Strive for aid. The Turkish Yearbook of International Relations, 27, 31-52.

Victory Monument and its immediate surroundings [Photograph]. (1929). Ankara Photograph, Postcard and Gravure Collection (Inventory no. 0990). Koç University VEKAM Library and Archive, Ankara.

View of Ankara [Painting]. (1700-1799). (Object no. SK-A2055). Rijksmuseum, Amsterdam. Retrieved from http:// hdl.handle.net/10934/RM0001.COLLECT.5695

Vincke, K. F. L. [Map]. (1846). Karte der Umgegend von Angora. (Call no. G7434.A6A1 1839.V5).

The University of Chicago Map Collection. Retrieved from https://luna.lib.uchicago.edu/luna/servlet/view/search?q=_ luna_media_exif_filename=G7434-A6A1-1839-V5.tif

Vincke, K. F. L. [Map]. (1854). Plan der Stadt Angora. (Call no. G7434.A6 1839.V5).

The University of Chicago Map Collection. Retrieved from https://luna.lib.uchicago.edu/luna/servlet/view/search?q= luna_media_exif_filename=G7434-A6-1839-V5.tif

Yalım, İ. (2001). Ulus Square as a representational form of collective memory. Unpublished MArch dissertation. METU, The Graduate School of Natural and Applied Sciences, Ankara.

Yalım, İ. (2017). Ulus devletin kamusal alanda meşruiyet aracı: Toplumsal belleğin Ulus Meydanı üzerinden kurgulanma çabası. In G. A. Sargın (Comp.). Başkent üzerine mekânpolitik tezler Ankara’nın kamusal yüzleri (pp. 157-214). İstanbul: İletişim Yayınları.

Yavuz, Y. (1994). 1923-1940 arası Ankara'da mimari. In E. Batur (Ed.). Ankara Ankara (pp. 201-208). İstanbul: Yapı Kredi Yayınları.

Yılmaz, M. (2019). Anafartalar'ı yıkmayacağız. Hürriyet Ankara Haberleri. Retrieved from http://www.hurriyet.com.tr/ yerel-haberler/ankara/anafartalari-yikmayacagiz-41222795 
